Andrews University

Digital Commons @ Andrews University

1981

\title{
A Christian Consideration of Polygamy
}

Jean-Jacques Bouit

Andrews University

Follow this and additional works at: https://digitalcommons.andrews.edu/dmin

Part of the Practical Theology Commons

\section{Recommended Citation}

Bouit, Jean-Jacques, "A Christian Consideration of Polygamy" (1981). Professional Dissertations DMin. 626.

https://dx.doi.org/10.32597/dmin/626

https://digitalcommons.andrews.edu/dmin/626

This Project Report is brought to you for free and open access by the Graduate Research at Digital Commons @ Andrews University. It has been accepted for inclusion in Professional Dissertations DMin by an authorized administrator of Digital Commons @ Andrews University. For more information, please contact repository@andrews.edu. 


\section{,}

ABSTRACT

A CHRISTIAN CONSIDERATION OF

POLYGAMY

by

Jean-Jacques Bouit

Chairman: Arnold Kurtz 


\title{
ABSTRACT OF GRADUATE STUDENT RESEARCH \\ Project Report
}

\author{
Andrews University \\ Seventh-day Adventist Theological Seminary
}

Tit7e: A CHRISTIAN CONSIDERATION OF POLYGAMY

Name of researcher: Jean-Jacques Bouit

Name and degree of faculty adviser: Russell L. Staples, Ph.D.

Date completed: November 1981

Since the beginning of its mission outreach in Asia and Africa, the Seventh-day Adventist Church has been confronted with the polygamy issue. Several attempts made by the church to formulate a unified policy for dealing with the polygamous convert culminated in the recommendation voted at the General Conference session in San Francisco in 1941. This resolution requires that in order to be admitted to baptism and church membership a polygamist must dismiss all his wives save one.

Recently, increased anthropological knowledge has led many Protestant churches in Africa to emphasize the legality of the marriage institutions in various societies. In doing so the theological problem of divorce in connection with the polygamous 
convert has become evident.

One notes from analyzing available records the absence of theological argumentation when the SDA church formulated policies regarding polygamy. The chief concerns seemed to be church standards, unity, and sensitivity to the social problems caused by the separation of the polygamous families. However, while such concerns are valid in their own right, they are too fragile a basis on which to build a policy that has such farreaching social and ethical consequences.

This project concerns itself with the formulation of a theological basis from which the church can deal with the polygamous convert. Since polygamy is a cultural as well as a theological issue, cultural considerations, anthropological analyses, and biblical principles are all helpful in establishing such a theological basis. The cultural and anthropological aspects show that polygamy is a valid marriage.

However, it clashes with the biblical ideal of marriage as symbolizing God's inclusive covenant relationship with man. The church, therefore, must uncompromisingly uphold the monogamous norm of marriage and its commitment to the ideal of indissolubility as well. At the same time, it must deal compassionately with the polygamous convert who, caught between the claims of monogamy and indissolubility, finds himself in a situation where full obedience is impossible. Here Paul's concessions to a less than perfect marriage, as indicated in 1 Cor $7: 8-18$ would seem to apply also to the polygamous marriage.

True to its teaching that the grace of God is sufficient 
to save man in whatever circumstances he finds himself, the church would admit polygamous converts to baptism after careful consideration of each case. Such an eventual change in the policy of the church should be accompanied by an active teaching program and must be carried out in a unified and cautious manner. 

A CHRISTIAN CONSIDERATION OF

POLYGAMY

A project report

presented in partial fulfillment of the requirements for the degree Doctor of Ministry

by

Jean-Jacques Bruit

APPROVAL BY THE COMMITTEE:

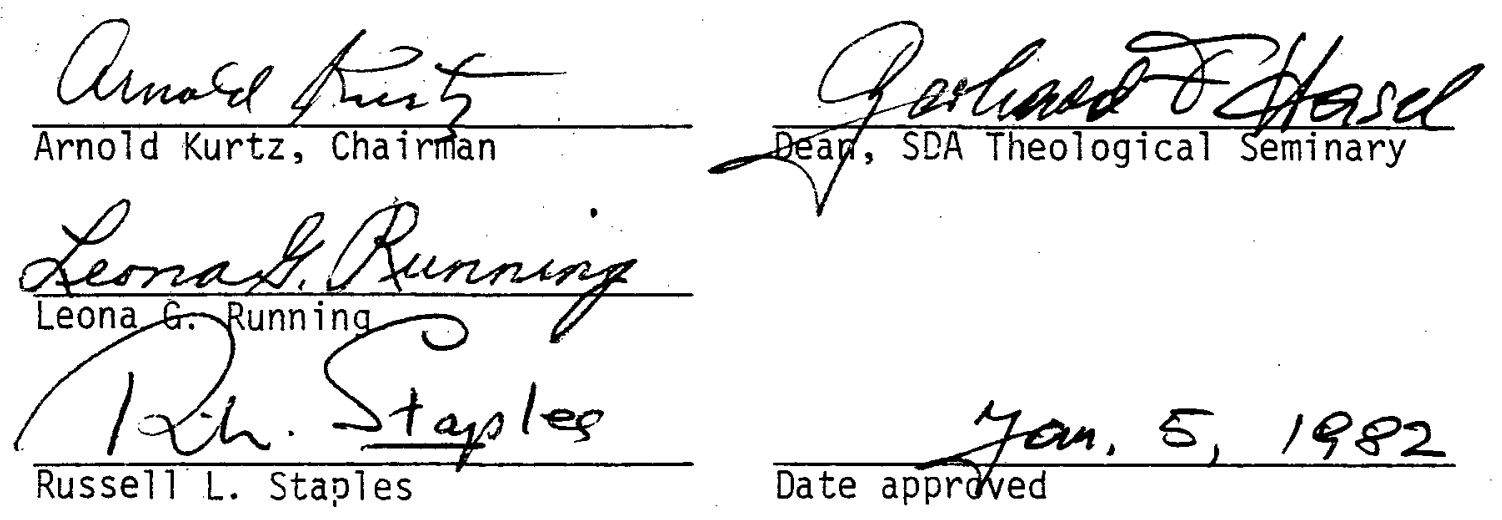




\author{
Andrews University \\ Seventh-day Adventist Theological Seminary
}

\title{
A CHRISTIAN CONSIDERATION OF POLYGAMY
}

\author{
A Project Report \\ Presented in Partial Fulfillment \\ of the Requirements for the Degree \\ Doctor of Ministry
}

by

Jean-Jacques Bouit

November 1981 
ACKNOWLEDGMENTS .............................. vii

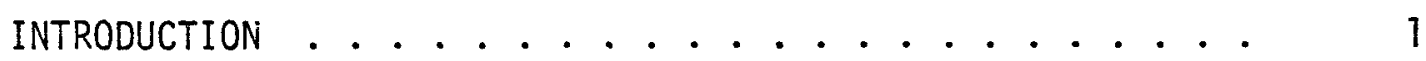

Purpose of the Study ............. . . . 4

Method of the Study ............... 4

Limitation of the Study . . . . . . . . . . . 5

Importance of the Study ............. 5

Chapter

I. CULTURAL CONSIDERATIONS ............. 8

Culture and Enculturation . . . . . . . . . 8

The Ethnocentric Predicament . . . . . . . . 10

The Relationship of Christianity and Culture ... 13

The Impossibility of Withdrawal

from Culture ........... 13

No Unique Model of Christian Culture ...... 15

The Search for Cultural Identity . . . . . . 18

Biblical Absolutism and Cultural Relativism ... 19

The Biblical Norm ............ 22

Essentials of the Faith and Adiaphora..... 23

Summary .................. . . . . 25

Conclusion ............... 2. 26

II. A SHORT ANTHROPOLOGICAL ANALYSIS OF AFRICAN MARRIAGE AND KINSHIP .............. 29

African Marriage and Kinship ........ . 29

Tribal Society . . . . . . . . . . . 29

Marriage in Patrilineal Society. . . . . . 32

Marriage in Matrilineal Societies....... 33

Stress on Group Significance and Procreation . . 35

The Problem of Childlessness ........ 37

The Levirate . . . . . . . . . . . . . 38

Functions of Polygamy ......... . . 39

The Problem of Divorce in African Society . . . . 43

Husband-Wife Relationship.......... 43

Problem of the Children ......... . . . 44

Legal Problem ............ . . . . 48

The Validity of Poiygamous Marriage . . . . . . 51

The Universality of the Nuclear Famity . . . 51 
Chapter

II. (Continued)

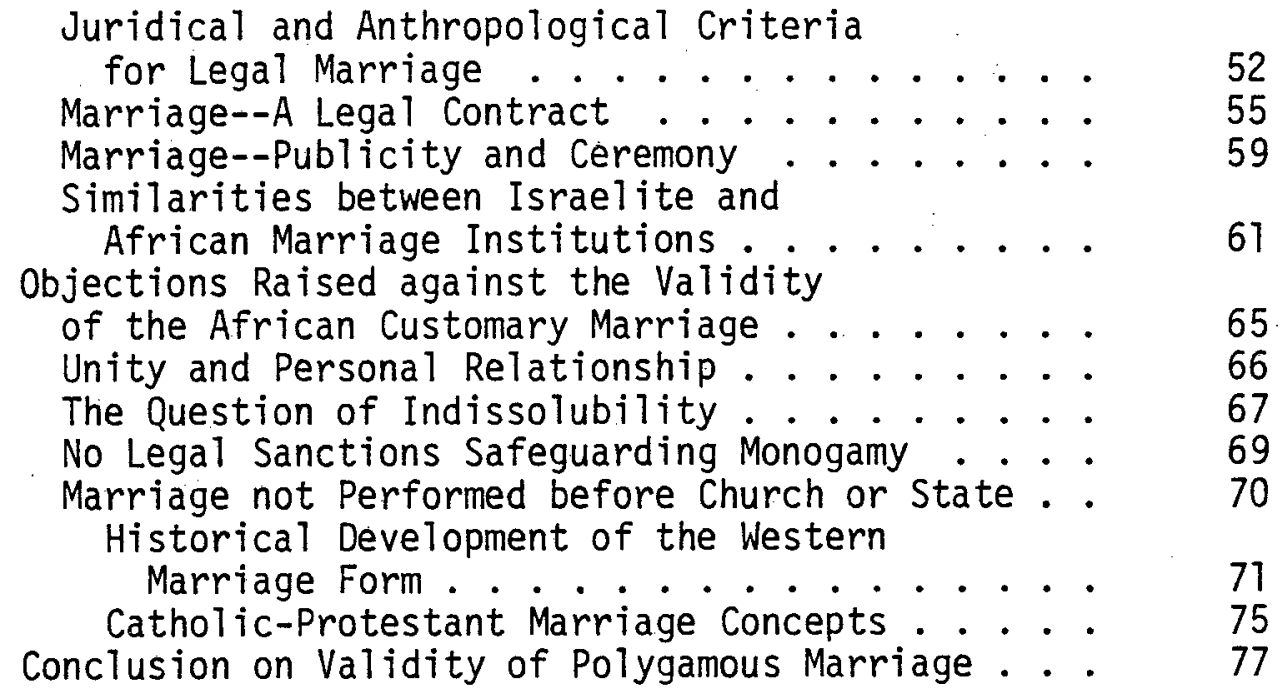

III. THE THEOLOGICAL AND BIBLICAL CONSIDERATIONS . . . . . 79

Textual Refutation of Polygamy ........ 79

The Scriptural Teaching on Marriage........ 82

Marriage--A Covenant Relationship....... 83

Marriage Imagery Used to Illustrate

Biblical Doctrines ............ 83

The Marriage Image as Reciprocal Illumination . . 86

The Biblical Norm of Marriage . . . . . . . 87

Reciprocity............... 88

Unity .................... 93

Permanency .............. . . . . 97

The Dilemma--Polygamy or Divorce . . . . . . 102

The Pauline Privilege . . . . . . . . . 103

Summary and Conclusion . . . . . . . . . . 107

IV. A HISTORICAL SURVEY OF THE CHRISTIAN

CHURCH'S DEALINGS WITH POLYGAMY . . . . . . . . . 109

General Historical Development ........ 109

The Monogamous Environment of the

Early Church .............. 109

Socio-Historical Backgrounds of the

Attitude of the Christian Church

toward Polygamy. . . . . . . . . . . 110

The Dealings of the Christian Church
with Polygamy .. . . . . . . . . . . 111

The Seventh-day Adventist Church and 118

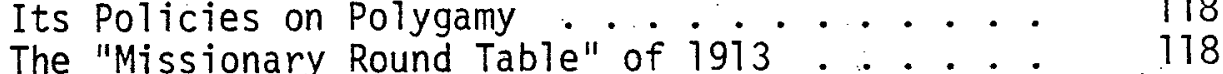

The Issues Raised . . . . . . . . . . . 120

Amendments to the Resolution ....... 122 
Chapter

IV. (Continued)

The 1913 Recommendation on Polygamy ..... 123

The Missionary Round Table of 1926 . . . . . . 124

Practices and Attitudes in the Various Fields .............. 125

The Difference in Practice between the European and African Divisions . . . . 129

The 1926 Recommendation on Polygamy and Marriage Relationships ....... . 131

Reflections on the Resolution of 1926 .... 133

The 1930 Resolution on Polygamous

Marriages in Heathen Lands . . . . . . . 134

The Background for the 1941

Resolution on Polygamy . . . . . . . 137

Developments after $1941 \ldots . . . . . .143$

Attempts to Accommodate the Policy to the
Practical Situation in Various Fields ..... 144

Fringe Membership.......... 144

Membership without Baptism or Baptism wi thout Membership .......... 146

Concluding Remarks ............ 147

V. EVALUATION, RECOMMENDATIONS, AND CONCLUSION .... 150

Evaluation of the 1941 Policy . . . . . . . 150

Recommendations ............. 156

Conclusion ................ 160

APPENDICES ............................. 165

A. Participants in the 1913 Missionary Round Table

Discussion .............. 166

B. Participants in the 1926 Missionary Round Table

C. General Conference of SDA (African Division)

D. Sixth Meeting, General Conference Committee,

E. Fourth Meeting, Friedensau, Germany,

F. J. I. Robison Obituary ........... 180

G. Actions of the Autumn Council, October 28 to November 3, 1930, Omaha, Nebraska ....... 183

H. Southern African Division--Polygamy ....... 187

I. Working Policy, Central European Division, February 3-11, 1939, Cairo, Egypt ........ 190

J. Polygamy, Statement of the General Conference from the Northern European Division . . . ... 192

K. Home and Foreign Officers' Meeting, May 20, 1941, San Francisco, California......... 198 
Appendices (Continued)

L. Proceedings of the General Conference Sixth

Meeting, June 5,1941 ......... 201

M. Committee on Polygamy, $1941 \ldots . . . . . .203$

BIBLIOGRAPHY ................... 205

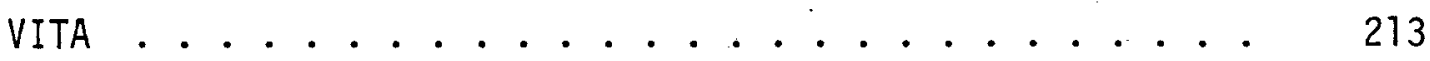




\section{ACKNOWLEDGMENTS}

This research project was made possible because of the valuable contributions of dedicated Christian teachers and friends.

Sincere gratitude is extended to Doctor Russell Staptes for his time and expertise in making this project a reality. Many thanks are also extended to Mrs. Joyce Jones for the corrections she made in the wording and form of this project and to Mrs. Joyce Campbell for her typing expertise and ability to meet deadlines. My wife Mildred deserves a special word of gratitude for having spent much time with me in gathering material for the research and for expressing encouragement and criticism during the development of the paper. 


\section{INTRODUCTION}

During a 1978 evangelistic campaign held in Abidjan, capital of the Ivory Coast, West Africa, Mr. Benoit, a member of the Ivoirian National Assembly and a very respected man in his community, decided to become a follower of Christ and a member of the Seventhday Adventist Church. Having completed the Voice of Prophecy courses, his interest in the message had grown until climaxed by a personal decision taken during the public meetings.

The decision of this man, who showed all the outward signs of conversion and who, by his personality and influence, could become a great help to the small, struggling church in Abidjan, normally would cause rejoicing. Instead, the days following his decision was a time of discussions among workers, of troubled conscience, perplexity, and disappointment. The reason? Mr. Benoit was a polygamist. His three wives, two of whom were older women, had all lived with him for many years. His thirty-one children ranged in age from preschoolers to married young people. Mr. Benoit was the respected center of a tightly knit family group.

In the SDA mission office, the French evangelist conducting the meetings, the expatriate mission-evangelist, four national pastors, and I struggled with the problem. The denominational policy is clear. It demands that a man found in a polygamous state when the gospel reaches him must put away all his 
wives except one, in order to be admitted into church membership.

But stating the policy is one thing, applying it on a human level is another. The dilemma was even greater because Mr. Benoit's case seemed to have none of the evils usually associated with polygamy. His household was a well-ordered and stable one. He was a good husband and father, genuinely concerned about the education of his children and the welfare of his wives. The thought of breaking up such a family with its accompanying social and cultural upheaval seemed cruel. What would be the reaction of the father's older children, some of whom were university educated and had ample opportunity to criticize the breakdown and immorality found within the western monogamous system? Might not the injustice done to their mothers prejudice them against any desire to know the Christian way? Contrasted with the prospect of bringing the total family under the gospel influence (which would certainly be the case if the father became a Christian and the family stayed together), the breakup of the family and the accompanying pain and hostility seemed senseless.

True, one could always slip into the easy attitude that Mr. Benoit could become a "fringe member" and attend church without being baptised. But knowing the African social structure and the deep psychological need springing from it for belonging and identification, this solution seemed hypocritical. It is, in reality, no solution at all.

The pastors all felt the tension of the situation. On the one hand was the concern and responsibility for the person brought to Christ and his family; on the other was loyalty to church policy 
and concern for unity. This concern becomes especialiy important in countries where members are young in the faith and in spiritual maturity. Great care must be taken to avoid confusing the people's minds because of ambiguity in attitudes and actions of the workers.

In Mr. Benoit's case it was decided to uphold church policy. The matter was explained to him. The disappointment and sorrow of this man I shall not easily forget. Although he expressed a desire to find a solution for his wives, it was clear that he really did not envision how any solution was possible. None of the pastors felt like pressing the matter.

I had dealt with polygamous cases before, but it was at this moment that the whole weight of the problem became real to me. My conscience was and still is troubled because of the action taken that day.

Mr. Benoit's story highlights the problems encountered by the church when bringing the Gospel to a polygamous society. Through its history of mission, the Christian church has continually been confronted with the practical problem of dealing with polygamous converts. Since 1941, the Seventh-day Adventist Church has had a unified policy which spells out the conditions under which a polygamous convert may be accepted for baptism and church membership.

In the forty years since this policy was put into effect, it has become abundantly clear that its enforcement has generated many social, ethical, and theological difficulties. A look at the policies of the church on polygamy as they developed through the years reveals that those involved in drafting them keenly felt the perplexity of the task and considered a satisfactory solution still 
an open question. Elder Spicer, then secretary of the General Conference, expressed this attitude when at the adoption of the 1913 recommendation he noted: "We may still learn more, and we may possibly unlearn some things." 1 This situation, therefore, demands a fresh examination of the policy of the SDA Church and the way it is applied in the African context.

\section{Purpose of the Study}

The purpose of the study is (1) to evaluate the dealings of the Seventh-day Adventist Church with polygamists in Africa in the light of anthropological analysis, biblical principles, and practical experience in order to assess whether the practice of the church in regard to the polygamous convert needs modification, and (2) to propose alternative solutions to the range of problems encountered.

\section{Method of the Study}

This is of necessity an interdisciplinary study covering a wide range of topics--cultural, anthropological, theological, and historical. A major concern of the project is to establish a theological basis on which to formulate recommendations for dealing with the polygamous convert.

The biblical concept of marriage is the ideal against which the polygamous norm must be tested. But one cannot evaluate polygamy in light of the biblical concept of marriage unless it is first established whether the polygamous union constitutes a valid

${ }^{1}$ General Conference of Seventh-day Adventists, "Missionary Round Table," 1913 (Washington D.C.: General Conference of Seventhday Adventists, Archives), p. 13. 
form of marriage. Furthermore, since polygamy is a cultural as we11 as a theological issue, it is necessary to consider the cultural obstacles which complicate a theological evaluation of the problem.

\section{Limitation of the Study}

This essay is concerned with the practical pastoral implications of the dealings of the church with polygamous families. It endeavors to draw information and arguments from the disciplines mentioned above, but it does not endeavor to deal exhaustively with all the concerns falling within the range of polygamy. Discussion is limited to such concerns and issues as relate directly to the task of evaluating the dealings of the church with polygamous converts.

\section{Importance of the Study}

Polygamy has been one of the most perplexing problems encountered by the missionaries bringing the Gospel to Africa. During the entire period of the presence of the Christian church on that continent there has never been a unified approach to the problem.

Polygamy has also been one of the most persistent obstacles to church growth. It has been estimated that in certain areas up to 90 percent of the adult population has been precluded from church membership because of polygamy. During later years, anthropological and cultural insights have prompted many missions to restudy and, in many cases, change their policies in regard to polygamy. Within the Seventh-day Adventist church, however, there has been no serious reevaluation of the issue for the last forty years.

More recentiy, the importance of inter-cultural communication 
has also been accentuated. In the colonial past, the problem of communication between the Westerner and the African was not so obvious because the traditional African confronted by the superiority or the power of a person or a system had a tendency to submit himself without asking questions. The missionary of yesterday, therefore, probably influenced people by the power of his prestige and example rather than by the force of his argument. Since the traditional African often simulates understanding in order to please, the missionary might have been blissfully unaware of the fact that he was not communicating successfulty at the verbal level.

In an era of colonial rule and autocratic leadership, this kind of interaction produced some positive results, but Africa has changed. As nationalistic states have emerged and the educational level of the African has improved, the prestige and power of the white man and his culture are fading and his orders and explanations are no longer blindly accepted. In some churches, national theologians have questioned the validity of church policies regarding polygamy. ${ }^{1}$ So far these pressures have been felt mainly outside the Seventh-day Adventist Church. The church, however, is reaching a crucial point in its history. Eighty percent of the SDA church membership is now in the third world, and, in spite of a strong overriding sense of unity and identity, pressure is mounting for more flexibility regarding local cultural concerns. The leadership of the church, therefore, must be sensitive to crucial issues at stake

${ }^{1}$ A German-trained national theologian precipitated the change of policy in the Presbyterian Church in 1972 at the Synod of Tamale, Ghana. 
in local cultures--such as the way the church deals with polygamy-and be sympathetic to assertions of cultural distinctiveness.

The way the church handles polygamists has far-reaching social and ethical implications. A church policy regulating the treatment of polygamous families who accept the Gospel must rest on a firm theological basis. It is in the dichotomy between the two biblical ideals of monogamy and indissolubility that the present policy exhibits a certain theological ambiguity. Polygamy is far from being a thing of the past, and the problems involved must be seriously addressed as the church presses forward in its commission of bringing the Gospel of Jesus Christ to the multitudes in Africa. 


\section{CHAPTER I}

\section{CULTURAL CONSIDERATIONS}

One of the main tenets of the Gospel is belief in an unchanging Christ. "Jesus Christ the same yesterday, today and forever" (Heb 13:8). But the unchanging Christ must be communicated in the context of a changing culture. The norms and values by which people live vary from society to society and cannot be accorded universal authority. But herein lies a problem, for a person such as a missionary is generally unaware of the extent to which culturally conditioned norms influence his/her concept of even ethical and theological absolutes. Because of the close contact existing between the Christian church and Western culture, the attitude of the churches toward polygamy have been influenced not only by theological considerations but also by the norms and values of Western Culture.

In this chapter attempts are made to indicate the cultural obstacles which complicate a theological evaluation of polygamy.

\section{Culture and Enculturation}

Klineberg defines culture as "the totality of the mode of life which is determined by social environment. "1 Herskovits

10. Klineberg, Race Difference (New York: Harper and Bros., $1935)$, p. 255. 
suggests that it is "the learned element in human behavior."1

Culture is the work of man's mind and hands. It includes

speech, education, tradition, myth, science, art, philosophy,

government, law, rites, beliefs, inventions, and technologies. It,

therefore, embraces all facets of 1 ife and is at attempt to cope

with human problems.

Culture as a design for living is a plan for coping with a particular society's physical, social and ideational environment. It is a complete and more or less successful system which includes the total content as well as the organization of the content. ${ }^{2}$

The child learns from infancy the basic values of his culture through the process of enculturation. Enculturation is

... both a conscious and unconscious conditioning process whereby man, as child and adult, achieves competence in his culture, internalizes the dreams and expectations, the rules and requirements, not just for the larger society seen as a whole but also for every specific demand within the whole. Society does what is necessary to aid any of its members in learning proper and appropriate behavior for any given social setting and in meeting the demands of any challenge. Enculturation begins before birth and continues until death. 3

A person from one culture may adopt the culture of another, but a many-sided learning process is involved. "One enters, in effect, as a child and is enculturated in the new society through the process of adaptation to that society. " 4 Vincent Guerry suggests that total understanding of another culture is nearly impossible:

\section{Merville J. Herkovits in F. M. Keesing, Cultural Anthropology} (New York: Holt, Rinehart \& Winston, 1958), p. 18.

${ }^{2}$ Louis J. Luzbetak, The Church and Culture (Techny, IL: Divine Word Publications, 1970), p. 64.

${ }^{3}$ Steven A. Grunlan and Marvin K. Mayers, Cultural Anthropology (Grand Rapids: Zondervan. Publishing House, 1979), p. 76.

4 Ibid., p. 85. 
It is always possible to adapt oneself to a culture, to learn the language and its way of thought. But the sensitivity remains untouched by its adaptation. The deep reflexes of our sensitivity are fixed from our earliest years. Thereafter it is not within our power to feel differentiy.

\section{The Ethnocentric Predicament}

Furthermore, understanding of another culture is difficult because one unconsciously refuses to grasp or even consider issues that threaten one's own cultural values. This blockage of understanding, most often, stems from the ethnocentric predicament. Ethnocentrism means judging another culture by the values and norms of one's own culture. It is a subtle psychological process--a way of 'closing' one's personality, of defending what one is, by rejecting whatever one is not. It is present in all cultures and has both a positive and negative side.

In its positive expression, ethnocentrism allows one to be satisfied and complete as a person within the context of his culture. In its negative effect, it subtly communicates the superiority of one's own over all others. The end result of ethnocentrism is reinforcement of one's own lifestyle, the inability or unwillingness to change, and the subtle demand that others change to become like ourselves to be fully accepted. 2

Ethnocentrism might be considered an expression of group solidarity. It originates in the psychological need of men to belong:

The need for security in a group of one's own, implies the necessity of identifying outsiders who are not permitted the privilege of membership. Linked with this is the universal difficulty which human beings have in projecting themselves into positions and point of view differing from their own. . . As distanced barriers have been broken down and contacts between groups have multiplied, each group's tendency to be

\footnotetext{
TVincent Guerry, La vie quotidienne dans un village Baoule (Abidjan: Inades, 1970), p. 22.

${ }^{2}$ Gruntan and Mayers, p. 88.
} 
defensive about its own ways of behaving has been increased. The expression of this defensiveness is a common manifestation of ethnocentrism. 1

Ethnocentrism distorts judgment:

He (man) mistakes his own cultural categories as universally correct, as a part of nature rather than a more or less arbitrary convention of his own people. When he encounters different patterns of judgment in another culture, he cannot help seeing them as erroneous. The acts that his culture has taught him to be immoral and unclean, he sees as immoral and unclean when done by others. 2

Ethnocentrism is a universal condition.

Even anthropologists are ethnocentric, more or less to some irreducible degree. .. . . No one, not even the anthropologist, is immune to the pervasive effects of enculturation. . . . Such residuals of ethnocentrism are 'blind spots' and do operate without awareness even in one who has set as his goal their elimination insofar as possible. 3

A11 are victims of the ethnocentric predicament, however subtle its expressions. It is very much part of the human condition. Christians communicating and solving cross-cultural issues must deal realistically with the ethnocentric problem. A realization of this human predicament makes one less tempted to rely on feelings and personal attitudes and more willing to view reactions critically-separating the basic issues at stake from emotional overtones.

This applies to both sides of the polygamy issue. For as nationalistic and cultural pressures increase in the third-world countries, the basic issue might well get lost in the sweep of emotion and cultural hostility. From the Occidental's side, a certain lack of sensitivity in regard to polygamy is no doubt due to

Haskel M. Miller, Barriers and Bridges to Brotherhood

(New York: Abingdon Press, 1962), p. 20.

${ }^{2}$ Melville J. Herskovits, Cultural Relativism (New York: Random House, 1971), p. xiii.

${ }^{3}$ Ibid., pp. xvi, xvii. 
cultural conditioning. The more "lenient" attitudes adopted by the SDA church in the later years towards divorce are seen by some as an indication of subconscious cultural preference. One is able to identify and empathize with the divorce problem because it is within our own cultural frame of reference. The exotic, "immoral" practice of polygamy, on the other hand is declared to be anathema. This judgment is partly based on biblical considerations, it is true, but it is also based on our culturally conditioned feelings. Referring to the polygamy issue in Ghana, C. G. Baëta notes:

Theological arguments played a minor role in determining the missionaries' attitude. Rather it was their feeling of the superiority of European culture and their identification of those things good and moral as European and conversely those things evil and immoral as African. They proposed to make Africa conform to the Victorian bourgeois society of England which appeared to them as the highest morality yet attained.

Lest there should be a misunderstanding of this point, it must here be made clear that biblical and theological considerations are extremely important in the polygamy issue and are, in this essay, treated separately.

What must be emphasized here, however, is that before endeavoring to attack the problem from a theological point of view, an attempt must be made to gain a certain objectivity of mind divested from cultural bias. One must realize that "biases though they seem natural enough to us, cannot be universally accepted." 2

${ }^{1}$ Christianity in Tropical Africa (London: Oxford University Press, 1968), p. 228.

${ }^{2}$ Herskovits, Cultural Relativism, p. 109. 
Given the force of one's own cultural background, this is an ideal that can be reached only through the regenerative power of the Holy Spirit.

We are tempted to think that we need a cultural revival in the church. In many ways this is true. But what is really needed is a spiritual revival, so that we are assured of the Holy Spirit leading through the cultural jungles. If we try to solve these cultural problems without an accompanying new work of regeneration and holjness, we can expect nothing more than a resurgence of pride. 1

The Relationship of Christianity and Culture

Another point worth considering when dealing with intercultural issues is the relationship between Christianity and culture. The Occidental civilization has traditionally been the bearer of the Christian faith. The question arises whether or not the message and the messenger have become confused in the process. Increasingly, educated Africans are asking, "What part of the Christian teaching on social questions developed from the authority of Christ and the criterion of love and which from western conventions and social system?" ${ }^{2}$

The Impossibility of Withdrawal from culture

The relationship between the church and culture has been a much debated issue. The radical Christian attitude of hostility and rejection of culture has had many adherents through the years, a

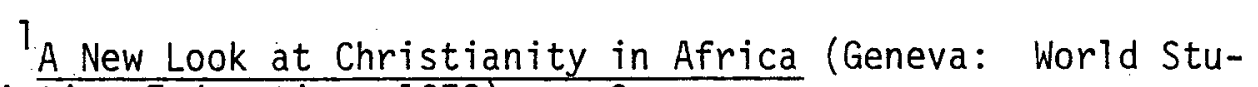
dent Christian Federation, 1972), p. 8.

2 Busia Kofi Abrefa, "Freedom and Unity in Christian Society," International Review of Missions 52 (July 1963):452. 
fact to which monasteries and hermitages may amply testify. Niebuhr points out that although the movement of withdrawal and renunciation is a necessary element in every Christian's life, it is not an adequate answer to the problem,

because it affirms in words what it denies in action, namely the possibility of sole dependence on Jesus Christ to the exclusion of culture. Christ claims no man purely as a natural being, but always as one who has become human in culture, who is not only in culture, but into whom culture has penetrated. Man not only speaks but thinks with the aid of language and culture. 1

In reality, it is impossible for the Christian to withdraw from culture. By attempting to do so, he is only creating a new form of culture. "Even a Christian minority which lives a hidden and persecuted life, like the early Christians in the ages of the catacombs, possesses its own patterns of life and thought, which are the seeds of a new culture. ${ }^{2}$

When God extended His gift of redemption to man, he came as man. He became a man in culture. He took a cultural name. He spoke a local language, received a cultural education, conformed to the cultural values of His people. "One aspect of the incarnation, and a very important one, is that the Son of Man revealed the Father in a particular cultural tradition. ${ }^{3}$

The New Testament is a missionary book in which the Gospel is made meaningful to those outside the cultural setting of

$1_{H}$. Richard Niebuhr, Christ and Culture (New York: Harper and Brothers, 1956), p. 69.

${ }^{2}$ Christopher Dawson, The Historic Reality of the Christian Culture (London: Routledge \& Kegan Paul, 1960), p. 68.

${ }^{3}$ New Look at Christianity, p. 5. 
Christ's incarnation. It addresses itself to "every nation and kindred and tongue and people" (Rev 14).

Paul, the greatest missionary of the early church, was sensitive to culture. "He was a Roman and a Jew and he was proud of both traditions; but he was always careful to adapt his teachings to the cultural background of his audience, whether they were simple, peasant-minded Anatolians or skeptical Athenians or supercilious Roman administrators." 1

No Unique Model of Christian Culture

The Gospel must then be communicated in the context of culture. But since man is fallen, culture, being his creation, is influenced by sin. The extent of God's influence on culture is a much debated question. Man was created in the image of God. God gave him a general revelation as stated in Rom $1: 19,20$ and Rom $2: 14,15$. He has also given him specific revelation through the Bible and His Son, Jesus Christ. However, man has continually defaced God's image in him and discarded His revelation. As he creates culture, "man sometimes does what pleases God, sometimes what God hates, and always less than God's wi11."2

All cultures fall short of the divine standard. There is, therefore, no unique model that can be pointed to as "the Christian Culture" conceived of as a symbiosis of faith and the mentality of a given society. Any culture can be brought under subjection to Christ.

TDawson, p. 16.

${ }^{2}$ Donald McGavran, The Clash Between Christianity and Culture (Washington, D.C.: Canon Press, 1974), p. 12. 
The only true criterion of a Christian culture, is the degree to which its way of life is based on the Christian faith. . . If its members possess a genuine Christian faith, they will possess a Christian culture, and the more genuine the faith, the more Christian the culture. 1

Thus, there may be a Chinese Christian culture as well as an Indian or African one.

Christianity is not a culture, neither is it a natural religion in the sense of being an expression of a society's religious needs. It expresses divine rather than human initiative. "Truth is of God and thus is not something of human invention or construction." 2 Christianity, therefore, transcends cultural limitations and can be a living force within every culture.

The gospel of Jesus Christ is tied to no one culture and allows the individual to transcend his own culture. This does not inany way imply that we attempt to establish a 'Christian culture'. Rather, it leads to a specific culture being regenerated by the work of grace within the heart and lives of the Christians living within the culture. 3

The Christian within the culture, then, becomes a leaven of cultural transformation. As members of a society pattern their lives upon the Christian faith, their culture is patterned more closely after the divine will, but it still falls short of that perfect wi1l. The tension between the Gospel and culture will always be a part of the human condition as long as life continues.

Much mischief has been done by confusing "Christian Culture" with one specific culture, namely, the Occidental. The expansion of Christianity in the non-European societies was

1 Dawson, p. 14.

${ }^{2}$ Marvin K. Mayers, Christianity Confronts Culture (Grand Rapids: Zondervan Pub7 ishing House, 1977), p. 23.

3 Ibid., p. 16. 
associated with the expansion of Western colonial power. Missionaries born and educated in a particular society inevitably took their own cultural traditions, habits, and prejudices with them. It is understandable then, that the Gospel message they proclaimed was given a Western flavor.

The Gospel came to Africa on the tidal wave of western cultural expansion. In the minds of many--both those who felt the tide coming, and those who were part of it--not much distinction was made between. Christianity and the culture of those westerners who carried the Gospel. Understandabiy enough, therefore, Christianity in Africa became very closely identified with a particular cultural form--that of the vigorous white empire.

Many Africans have associated Christianity with Western civilization and have hesitated, therefore, to embrace the Christian teachings and way of life upheld by the churches, fearing that in so doing they would have to accept a culture incompatible with their own traditions. In their zeal and devotion to the Gospel and its expansion, the early missionaries often came to Africa with the notion that local customs were evil and needed to be changed. Because they did not distinguish their culture from the Gospel, missionaries often tenaciously clung to the cultural elements of their adaptation of the faith and, in that way, hindered expansion of the Gospel. Two processes are involved when the Gospel is brought to another culture:

. . . the 'undressing' of Christianity from the foreign culture, and the 'dressing' of Christianity in the indigenous culture. These processes, however, are simultaneous, since Christianity cannot exist without some dress or other. You cannot have a 'culturally naked Christianity'.?

\section{${ }^{1}$ A New Look at Christianity, p. 4.}

${ }^{2}$ Aylard W. F. Shorter, African Culture and the Christian Church (London: Jeoffrey Chapman, 1973), p. 69. 
The task of the Christian church is not "to create a new people in Africa. It comes rather to put into touch with the divine message a people created by God. It comes to apply to them divine revelation and divine redemption, to the people itself and to all that is good, rational and truly human in its culture and institutions." 1

The Search for Cultural Identity

As Christianity has often been confused with Western culture in the minds of the thinking Africans, the rejection of the domination and culture of the colonial powers (a phenomenon predominant in the new surge of nationalism) has led to the rejection of Christianity itself.

When things western are under suspicion in Africa, where will the church be? Will it be so closely tied with western culture and way of life that it too will come under censure? There may be no more serious question facing the church in Africa than this.2

Rightful nationalism in developing countries has in many places led to an accommodation of the Gospel to African traditionalism, with "prophets" and "messiahs" arising from among the people, partly as a reaction against Europeanization and Christianization. Such movements are often a result of frustration and "generally a reaction against suppression by a dominant culture. Nativism, therefore, is usually an attempt to restore group integrity, selfrespect and solidarity. . Essential to the concept is the conscious striving of the people to restore or perpetuate traditional ways. " 3

${ }^{1}$ Baeta, p. $300 . \quad 2$ A New Look at Christianity, p. 6.

${ }^{3}$ Luzbetak, p. 249. 
A reaction against the fusion of Christianity and Western culture has set in. Some churches, aware of the errors of the past, have tried to adjust their message to the African way. Unfortunately, the results have often been half-pagan cults in which the essentials of the Christian message have been sacrificed. The great danger when introducing the Gospel to various cultures is to lose sight of the transcendental character of the Gospel message. This may result in the reduction of Christianity to the level of any natural religion. This takes place when norms and values of the Faith are conformed to the models already existing within the culture.

When the gospel is only a gospel of adaptation, the socialized gospel, we are really near the simple civil religion which makes society and culture sacred, but that JudeoChristianity has always rejected as idolatry. The worship of culture, meaning the tendency of reducing transcendental faith to a mere culturaliy adapted expression of socio-cultural values, would not be an outstanding contemporary form of idolatry. 1

Biblical Absolutism and Cultural Relativism

In the encounter of Christianity with African culture, there are two tendencies which must be discouraged. On the one hand, there is the danger of confusing the Gospel with Western civilization. This results in the transportation of an amalgam of Christianity and culture into a society with a vastly different culture and generates a fundamental clash between the two different cultural systems. This may be seen as an example of the confusion of cultural absolutism with bibilical absolutism. A cultural absolutist does not distinguish between biblical absolutes and his/her

IFrançois Faucher, Acculturer 1'Evangile: Mission prophétique de l'Eglise (Montreal: Fides, 1973), p. 68. Transiation by J. J. Bouit. 
cultural expression of such absolutes. "Biblical absolutism becomes merged forever with cultural absolutism. Anyone not supporting such absolutism, they feel, must be a relativist and not believe in absolutes in any sense." 1 The second danger is that of relativism. Attempts at cultural adjustment may lead to the formation of Christo-pagan cults in which biblical principles are abandoned. In this case, biblical absolutes have been discarded along with cultural absolutes.

A view combining biblical absolutism with cultural relativism ${ }^{2}$ avoids the pitfalls of either tendency. Biblical absolutism indicates that there is universal truth, and that this truth can be expressed in different cultural forms without suffering adul teration.

The approach of biblical absolutism and cultural relativism, affirms that there is supernatural intrusion. This involves act as well as precept. Even as Christ, through the incarnation became flesh and dwelt among us, so precept or truth becomes expressed in culture. However, even as the word made flesh lost none of His divineness, so precept loses no truth by its expression via human cultural and social forms. It is always full and complete as truth. 3

Christianity may then be expressed through various sociocultural forms while remaining true to God-given revelation. Such expressions must not be contrary to the absolute principles of truth revealed in the Word and in the life of Jesus Christ. No essential element of Christianity must be lost or distorted. Therefore "some adjustments to culture must be rejected. That the custom

1 Mayers, p. 232.

${ }^{2}$ For a distinction between cultural relativism and relativism, see Mayers, pp. 70, 231, 232.

3 Mayers, p. 233. 
is part of a given culture is not sufficient reason to incorporate it into Christian practice. It must also be agreeable to Christian revelation." 1

If there is tension between an aspect of a given culture and the biblical absolutes, the offensive cultural component must yield to revealed truth. Paul speaks of

.. engrafting Christ (Rom $11: 19,24)$ and 'grafting' when speaking of society is 'cultural surgery'. The same thought is conveyed when the Apostle speaks of the necessity of ridding oneself of the 'old man' and putting on the 'new' (Col 3:9-10). . . Compromise is impossible when 'surgery' happens to be the only means of saving the true and full meaning of the gospel.2

If the initiative of "cultural surgery" comes from outside the affected culture, there must be a careful attempt to ascertain whether or not the problem is being viewed through the "colored glasses" of one's own culture.

Mayers offers suggestions on how to deal with cross-cultural issues when it is felt that there is a need for change. According to him, in such a situation the following questions must be considered:

1. What is the norm (denoting that which is normative, that which is the foundation for expectation within the society)?

2. Is the person living in keeping with this norm?

3. Does the norm need changing?

4. Who is responsible for changing the norm?

Mayers points out that

the average, well-meaning person, untrained in cross-cultural communication, asks only questions three and four. Thus, he will find that anything different from his own lived experience needs

IMcGavran, p. 23.

2Luzbetak, pp. 183, 184. 
changing. When he gets to question four, therefore, he stands in the primary position of responsibility for changing the other norm. When one begins with the first question, however, a whole new experience awaits him. .. He becomes aware that the other person is as fully responsible as he is himself. Then when he gets to question three, he realizes that both norms may need changing, or that either his or the other norm may need changing, or that neither needs it. Then when he proceeds to the point of considering change, he does not go alone; he goes with the person of the other cultural viewpoint. 1

This approach opens both norms for change under the guidance of the Holy Spirit: "Once the norm of each is open to change, there is a viable role for the Holy Spirit of God to enter and guide either or both in the change process. ${ }^{2}$

The Biblical Norm

As both norms become open to change, the need for an objective external standard becomes evident. Here the importance of the Bible revelation becomes clear:

The Scriptures in the form of the Bible, provide the standard. The first person, along with the other person i.e. both the one whose norm needs changing and his support person work with the Scriptures in the language that they can both understand and respond to as the 'very Word of God'. 3

The African Christian cannot pretend that the biblical revelation never was made or only has interest for the Western Christian. It is true that it was within the Jewish culture that the mystery of Christ was revealed to mankind, and that the New Testament writers expressed concepts in terms of Jewish and the newly dominant Greek cultures. But the Scripture given by divine inspiration has the capacity of transcending cultural boundaries. ${ }^{4}$ White notes:

$$
\text { Mayers, p. 23. 2 } 2 \text { Ibid., p. } 234 . \quad 3 \text { Ibid., p. } 235 .
$$

${ }^{4}$ The scope of this project does not allow a discussion of the problem of hermeneutics; thus we merely state that this essay is 
The Bible was written by human hands; and in varied style of its different books it presents the characteristics of the several writers. The truths revealed are all 'given by inspiration of God' (2 Tim 3:16) yet they are expressed in the words of men. The Infinite One by His Holy Spirit has shed light into the hearts and minds of his servants. He has given dreams and visions, symbols and figures, and those to whom the truth was revealed, have themselves embodied the thought in human language. 1

The revealed truth has been preserved from corruption: "It [the Bible] came fresh from the Fountain of eternal truth, and throughout the ages a divine hand has preserved its purity. "2 It follows that the Jewish scriptures are valid and indispensable for al1 Christians of whatever culture they are a part, and that the church can never dispense with the Bible in the form in which it was written. "The Holy Scriptures are to be accepted as an authoritative revelation of His will. . . "3 "The truths revealed unite to form a perfect whole, adapted to meet the wants of men in all circumstances and experiences of 1 ife. $" 4$

\section{Essentials of the Faith and Adiaphora}

Luther made a distinction between the essentials of theological truth and matters of relative value--adiaphora. The essentials may be designated theological and ethical Christianity

based on the understanding that the Scriptures have the capacity of transcending cultural boundaries.

'E. G. White, The Great Controversy (Mountain View, CA: Pacific Press Pub. Assoc., 1911), p. v.

2E. G. White, Counsels to Parents, Teachers and Students (Mountain View, CA: Pacific Press Pub. Assoc., 1913), p. 52.

White, The Great Controversy, p. vii.

${ }^{4}$ Ibid., p. vi. 
and are characterized by their explicit foundation in Scripture revelation. Heppenstall comments:

We must refuse to regard as essential what is not firmly rooted in the Scriptures. The absolute truths of Christianity came not from Augustine or Calvin or from Thomas Aquinas or Martin Luther, or from the Adventist Church, but from the Holy Bible. The doctrine of sacred Scripture, miraculously inspired and authoritative, is indispensable to the Christian faith and to the church itself.1

As regards theological and ethical Christianity the biblical principles remain unchanged in all cultures, while their practical applications in various cultures might vary. For instance, the command to honor one's father and mother remains valid for all cultures but the manner of the practical application of the mandate obviously varies considerably. In the same manner the command "thou shalt not steal" remains valid for all cultures, but the concept of what constitutes theft is culturally conditioned. 2

If there is a suspicion that a cultural application contradicts the principle itself, and an objection is raised from outside the particular society (as in the relationship between a missionary and the people among whom he is working), the bicultural approach outlined earlier may be used in an attempt to settle the issue.

Adiaphora deal with the externals of the church (meaning everything having direct relationship to outward forms of the church). They comprise church customs, worship forms, etc., which are not part of Bible revelation and extend into the customs of everyday life. They are often culturally conditioned and may be modified

\section{'Edward Heppensta11, "Creed, Authority and Freedom,"}

Ministry, April 1979, p. 14.

$$
{ }^{2} \text { See Mayers, pp. 230-31, for discussion. }
$$


in response to cultural needs. A holistic concept of man recognizes that his total experience is under the influence of biblical principles; therefore, also the externals are consistent with Christian vaiues. But as they comprise ideas neither enjoined nor forbidden in the Scriptures, they are left to individual conscience. Through cultural conditioning adiaphora often become confused with absolute truth. When this is the case, any adjustment in adiaphora according to cultural need may be frowned upon as abandonment of principle. "Unfortunately adiaphora tend to become like sacred cows of India. The non-essentials, even those dear to us, must be sacrificed. This is one of the costs of church-growth." 1

\section{Summary}

When approaching an inter-cultural, theological problem such as polygamy, certain propositions must be kept in mind:

1. Al1 cultures fall short of the divine standard. There is, therefore, no unique model of a Christian culture which is the "Christian Culture" conceived as a symbiosis of faith and the mentality of one society. Christianity transcends cultural limitations and can be a living force within every culture. The tendency to confuse "Christian Culture" with one specific culture, namely, the Occidental, must therefore be resisted.

2. Biblical absolutism should be distinguished from cultural absolutism. The elevation of adiaphora to the same level as absolute truth is often culturally conditioned and must be resisted when dealing with cross-cultural issues.

TJoseph Conrad Wold, God's Impatience in Liberia (Grand Rapids: Eerdmans, 1969), p. 153. 
3. The danger of losing or distorting necessary elements. of Christianity as it flows into each culture must be guarded against. Adjustments to culture which do away with essentials of the Gospel revelation must be rejected. The Bible must be considered authoritative. It was given by divine inspiration and, therefore, has the capacity of transcending cultural boundaries. It is the objective and external standard, valid and indispensable, for Christians of all cultures.

4. The problem must be approached with an attitude of cultural objectivity. The fact of ethnocentrism must be recognized and dealt with realistically so that the problem of "blind spots" is minimized.

The mediation of the Holy Spirit is vital to the task of removing cultural bias.

\section{Conclusion}

From the principles that have been presented in this paper thus far, several points may be made.

In the process of evaluating the African norms of marriage one must refrain from comparing these norms with those established by custom in Western cultures. To compare African with Western norms of marriage would be cultural absolutism. In addition, the forms of African marriage must not be judged by their lack of conformity to the externals of the church such as wedding rites, etc. (these are part of the adiaphora). In order to decide whether the polygamous norm is acceptable to the Christian, one must test it in the light of absolute truth as revealed in the Bible. The biblical concept of 
marriage, then, is the only norm against which the cultural expression of polygamy is to be evaluated. Such an evaluation must be approached in an attitude of objectivity, and the tendency to interpret Scripture in the light of one's own socio-historical background must be resisted.

Mayers suggests four questions when attempting to resolve cross-cultural issues. ${ }^{1}$ Chapter 2 of this paper deals with two of these questions: (1) What is the norm? This is an attempt to understand the cultural system which is the matrix of the custom of polygamy. (2) Is the person living in keeping with this norm? Because there are biblical absolutes against which all cultural expressions must be judged, it is necessary to evaluate the polygamous norm in the light of Bible revelation. This brings in Mayers' third question: Does this norm need changing? This we endeavor to answer in chapter 3 , ever conscious of the necessity to test the polygamous norm according to biblical principles and not in the light of one's own cultural norms.

Chapter 4 is a short historical survey of how the Christian Church has dealt with the polygamous convert. Particular stress is given to the development of the policy of the Seventh-day Adventist Church regarding the polygamy issue.

Without doubt, Mayers' fourth question, who is responsible for changing the norm?, creates the most tension with the church body. The final chapter evaluates the position of the SDA church as it effects polygamous families and, in the light of findings

${ }^{1}$ See p. 21 above. 
revealed through the development of this study, proposes alternative solutions to the problem. 
CHAPTER II

A BRIEF ANTHROPOLOGICAL ANALYSIS OF AFRICAN MARRIAGE AND KINSHIP

One should bear in mind that in this chapter we are not concerned with a moral evaluation of either polygamy or of the social conditions underlying it. The purpose is:

1. To describe some of the social, economic, and ideational factors underlying polygamy

2. To explain the problems created in such societies by separation of the marriage partners

3. To establish that polygamy is a valid form of marriage.

\section{African Marriage and Kinship}

Tribal Society

It has been pointed out that culture, as a design for living, is a plan for coping with a particular society's physical, social, and ideational environment. African marriage must be seen in this light. These marriage systems developed from the specific needs of tribal society and can be understood only in reference to tribal order with its kinship system. In Western culture, there is a strong differentiation between politics, religion, economics, and kinship. It is therefore difficult to understand the tribal order where the family pattern is adapted to the whole political 
and economic structure. The smallest units--households--are segments of more inclusive units--lineages. Lineages, in turn, are segments of larger groups--clans, and so, like a pyramid of building blocks, all the social groups within a tribe are encompassed. The importance of kinship in tribal societies lies in the fact that in smal1 communities where all social relations are direct and personal, where all cooperation is by actual contact, where solidarity and substitution operate within groups of people in touch with each other, the family pattern can easily be adapted to the whole political and economic structure. Among the Ashanti, for instance, kinship and political authority interpenetrate. The Ashanti lineage is a
- . genealogically demarkated and rigorously exclusive association of persons of both sexes and all ages and gener- ations. - . . A free person can belong to one and only one lineage and can under no circumstances transfer his membership from his lineage of birth to any other. This is a politico- jural requirement for the unequivocal determination of citizen- ship. . A clantess person is by definition a slave. ... Externally his lineage binds him so irrevocably that he could not in precolonial period renounce it and remain in society as a free citizen. Even today, when many jural capacities and attributes of civic status are derived from the modern state structure, it is unthinkable for an Ashanti to renounce his ineage membership. To do so would be deleterious not only to his personal 7 ife, but to his public activities as well. Formerly, it could, however, be forfeited as a person could be expelled from the lineage for outrageous misconduct. . . . This was tantamount to outlawry and like capital punishment, to which it was virtually equivalent, required the assent of the king. 1

According to Sahlins, marriage within the African kinship system is a means by which the lives of entire lineages are solemnly united by exchange of daughters. It can be an arrangement of

Meyer Fortes, Kinship and the Social Order (London: Routledge and Kegan Pau1, 1969), pp. 184, 185. 
political importance, amounting to main lines of political alliances, and even, in some instances, substituting for extensive descentgroup relations. Sahlins also stresses that in tribal societies, marriage often follows a reciprocal pattern as "each lineage is bound by complementary relationships to two other lineages in the series, standing as 'wife givers', to one, and 'wife receivers' to another." 1 In practice, however, more leeway is then given as there are possibilities of adding supplementarities to the alliance network.

What characterizes African marriage and differentiates it from the Western counterpart is the establishment of a wider communal relationship. It is not regarded primarily as the concern of the spouses, but as the center of interest of the kinfolk on each side. African marriage is then regarded primarily as an alliance between two kinship groups and only secondarily as a union between two individuals. In fact, Ekundare comments that "customary marriage is a contract between two families, rather than a contract between husband and wife alone." 2

In a society with high infant mortality and where the average life expectancy of a male in 1930 was twenty-nine years and in 1960, thirty-nine (compared with seventy-five in Western society), the greatest internal threat to the lineage is barrenness. There is, therefore, a tremendous stress in African marriage on procreation,

1 Marshall Sahlins, Tribesmen (Englewood Cliffs, Nu: PrenticeHall, 1968), p. 56.

${ }^{2}$ R. O. Ekundare, Marriage and Divorce under Yoruba Customary Law (I1e Ife: University of Ife Press, 1969), p. 25. 
as each lineage recruits new members through matrifiliation or patrifiliation.

Marriage in Patrilineal Society

In the patrilineal society,

- . . the husband not merely claims wifeiy services, but the woman as a child-bearer, her progeny. . . The children belong to him and his lineage, who in the event of his demise may perpetuate the group interest by supplying another husband (e.g., the deceased man's brother) (levirate). As a matter of lineage persistence, a marriage can outlast the particular partners to it. This importance of marriage to the lineage as a corporation is manifest more particularly in the durability of husband-wife relations, and the complementary dilution of a married woman's relations to her brother--standing for her lineage of birth. ${ }^{2}$

In the patrilineal system, then, a father-son-brother constellation is found with the woman's role strictly as a wife and mother and the children belonging to the father's lineage. Staples notes that such societies are characterized by:

1. Rigorous clan exogamy (sexual liaison between members of the same clan is regarded as incest; men from one clan must marry women of another clan)

2. Stress on pre-marital chastity (sexual congress within the clan would break down the system of exogamy)

3. The payment of the bride wealth or lobola which compensates the wife's family for their loss of a daughter and for the children she raises for the husband's lineage

4. Stable marriage relationships (often no institutionalized form of divorce available)

${ }^{1}$ In most African societies there is a system of unilineal descent. An individual will trace his descent and receive his inheritance either in his father's line (patriline) or in his mother's line (matriline), but not in both (as is the case in Western societies). Children are regarded as belonging either to the father's or mother's 1 ineage.

$$
{ }^{2} \text { Sahlins, p. } 66 .
$$


5. The Levirate.

It is also to be noted that strongly patrilineal societies tend to have large polygamous families.

The majority of patrilineal groups recognize the legal husband of the mother as the father of the child irrespective of whether or not he is the physical genitor. In a minority of African social groups, the child belongs to the actual physical genitor. Such societies tend to have low bride wealth, as it does not guarantee a man the children of his wife. Marriage in such societies also has a tendency of being unstable as "the rule that a child goes to its physical genitor and not to the legal husband of the woman, removes the main buttress of marriage." 2

Marriage in Matrilineal Societies

In a matrilineal society, "a man's heirs are his sister's children, not his own; and lineage continuity rests with the control of his sister and her offspring, not with his wife and hers." ${ }^{3}$ Here the constellation mother-daughter-brother-sister with children beTonging to the mother's lineage is found. In the Ashanti ethnic group, for instance, "a brother has the legal power over his sister's children, because in this matrilineal society he is her nearest male equivalent, and legal power is vested in males. A sister has claim

TRussell L. Staples, "The Church and Polygamy in Sub-Saharan Africa," An unpublished working paper produced at the request of the General Conference, September 1981, pp. 6, 7. (Mimeographed.)

${ }^{2}$ See M. Gluckman, Kinship and Marriage among the Loze of Northern Rhodesia and the ZuTu of Natal in African Systems of Kinship and Marriage, ed. Radcliff-Brown and Forde, p. 201.

${ }^{3}$ Sahlins, p. 66 . 
on her brother, because she is his female equivalent and the only source of the continuity of his descent line."

The following patterns of marriage may be noted among matrilineal societies:

1. Matrilocal residence

2. Patrilocal residence ${ }^{2}$

3. No bride wealth (The legal possession of the girl's children is not being handed over by marriage and therefore no compensation is required; symbolic gifts often conclude the marriage contract.)

4. Less regard for premarital chastity

5. Less marital stability

6. Greater tendency to monogamous households ${ }^{3}$ (Existing polygamous families are generally smaller.)

In summary, then, in patrilineal society the man has the right over the sexual, domestic, and reproductive services of his wife; while in the matrilineal society, the man has the right over the first two, but never over the third. This part remains with the wife's lineage. Fox notes that in a patrilineal system, a man (and his lineage) gains complete rights over the possession of his own children; in a matrilineal system, he (and his lineage) has no rights over them. ${ }^{4}$

1A. R. Radcliff-Brown and Daryll Forde, African Systems of Kinship and Marriage (London: Oxford University Press, 1964), $\mathrm{p}$ 275.

${ }^{2}$ Staples stresses the general instability of such marriages. The mother tends to follow her children when these grow up and move back to the matrilineal family.

3 Hastings notes, however, that the Akan people of Ghana are an exception. They are both matrilineal and very polygamous.

${ }^{4}$ Robin Fox, Kinship and Marriage (Baltimore: Penguin Books, 1967), p. 121. 
The majority of the people in West Africa are patrilineal, but an important matrilineal enclave is formed by the Akan-speaking peoples of Ghana, the Ashantis, and the Baoule and Agni of the Ivory Coast. Some of the non-Islamized people in Northern Nigeria and those of the Bameda province in the Camerouns are also matrilineal.

\section{Stress on Group Significance} and Procreation

It is through marriage that the lineage is augmented by the offspring of the marriage partners. This emphasis on procreation and lineage membership must be seen against need for mutual security as found within the lineage. This need is a strong incentive to rigid kinship ties and marriage patterns. Malinowski notes:

- . in primitive societies, any form of what might be called "social insurance"--that is, organized assistance and replacement in case of death and misadventure, such as we have in the charitable and benevolent institutions of civilized communities--can only be done directly and personally. We see, accordingly, in primitive societies an extraordinary development of what might be termed substitution by kinship and a definite system of vicarious duties and responsibilities devolving on the nearest kin.1

The strong kinship ties reinforced through a predictable and stable marriage pattern allow for intimate cooperation among kinsmen and offer the possibility of greater wealth and protection. In the traditional African marriage institutions then, the ties formed and the offspring produced are of great importance to the survival of the society, and the stress is upon group significance and procreation.

1 Bronislaw Malinowski, Sex, Culture and Myth (New York: Harcourt, Brace \& World, 1962), p. 73, 
The importance of securing legitimate descendants accounts for the most characteristic features of African marriage law. . . . Although there are great differences between patrilineal and matrilineal descent systems, the importance attached to procreation and 'ownership' of children seems to be common to both.

In a society with such emphasis on procreation, a man with many wives and children is treated with respect. Therefore, "there is nothing which the untutored African covets more than a numerous progeny. Children as they grow up to maturity enrich him, give him preeminence and respectability in society, and when he is dead they perpetuate his name among men." 2

The practice of polygamy must be seen against this background. As noted by Westermarck,

It appears to express one aspect of the effort to build up at a primitive level of social organization, the largest possible unit of reproduction and defense. The mutual responsibility between a man and his wife's kinfolk extended the field in which he could move with assurance and security. The more wives he acquired, the wider the field. Moreover, each wife could be expected to bear a family of her own, and these together would make a large body of producers under a single direction and contributing to a single center. 3

It should be noted that the goal of numerous progeny for the society as a whole is not always well served by polygyny. "Magho-Naba-Kom who died in 1946 had 350 wives and only 42 children. The celebrated Sultan of Founbom in the Camerouns, Neljaya, had 147 children despite the fact that his wives at one time numbered $1200 . " 4$

TArthur Phillips, ed., "An Introductory Essay," in Survey of African Marriage and Family Life (London: Oxford University Press, 1953), p. xvii.

2Edward Westermarck, The History of Marriage, vol. 3 (London: Macmillan \& Co., 1921), p. 77 .

3 Ibid.

${ }^{4}$ Marie-André, The House Stands Firm (Milwaukee: Bruce Publishing Co., 1962), p. 96. 
Here then, the fertility per woman is decidedly less than is generally the case in monogamous households. Yet, generally speaking, polygyny has a tendency to increase the number of children born to the same man.

\section{The Problem of Childlessness}

Because of the great stress on procreation, a childless marriage is a major tragedy to an African couple. It has moral repercussions on the husband and wife. In the Ashanti society, for instance,

Just as legitimate paternity is a sine qua non for entirety of moral and jural filial status, so it is considered to be indispensable for the fulfillment of manhood. A man of appropriate age, who is not a father after a lengthy marriage, is defective in the same way as one who has suffered a bodily mutilation or is physically infirm, and is debarred from election to office. He is an incomplete person and people expect him to be psychologically disturbed.

Sterility then is considered a most deplorable misfortune. Its unfortunate victims have to endure contempt and derision. But two ways have been designed to cope with the calamity of a childless marriage. First, if the husband is the cause of sterility, a man other than the husband is allowed to have sexual relations with the wife. Price notes here that "this view permits a proxy father to beget children in the name of an impotent husband, whose marriage is then enabled to fulfill itself in the bringing up of another generation. "2 Second, if the wife is proven as the cause of sterility, "her sister may accompany her to live in her household, help look

IFortes, p. 197.

${ }^{2}$ Thomas Price, African Marriage (London: SCM Press, 1956), p. 23. 
after her children, and bear children to her husband. . . "I Here then, the children of the sister may be counted as the children of the barren wife. Since barrenness involves social dishonor to the wife, she often insists that the man fulfills his obligation by taking her sister as a second wife.

\section{The Levirate}

Levirate is practiced in many patrilineal societies of Africa. A man inherits the wife of his deceased brother and begets children in his name. The importance of the levirate custom has been ascribed to the fact that "among patrilineal people where marriage secures children to perpetuate the father's group and marriage involves lineage groups rather than individuals, the levirate union can be seen as part of the network preserving the perpetuity of the lineage groups and the security of each individual in them. ${ }^{2}$

The levirate marriage, therefore, is considered a continuation of the original marriage and is a way of providing social security for widows. Among the Yorubas of Nigeria, it must be proven conclusively that a woman was married under customary law before she can be inherited. In Comfort Adetutu versus V. J. K. Agbeniyi, the customary court ruled as follows:

that a girl on whom dowry has been paid but who has not been formally delivered to the 'fiancé,' is not married under

I Ibid., p. 23.

${ }^{2}$ Michael C. Kirwin, The Christian Prohibition of the African Leviratic Custom (Ann Arbor: Xerox University Microfilms, 1974), p. 259 . 
native law and so cannot be inherited on the death of the man. .. The acceptance of the offer to remain in her husband's family will not lead to any fresh marriage contract and ceremony. The second marriage is regarded as a continuation of the original contract. 1

The levirate custom is aimed at procreation and social security and is not, usually, a result of sexual indiscipline.

\section{Functions of Polygamy}

Polygamy as an expression of the promiscuous tendencies in unregenerated man cannot be overlooked. The tendency to consider such union as merely a sexual arrangement, however, has been greatly exaggerated. Polygamous marriages, in general, are contracted as result of pressures, expectations, and duty within a society rather than for personal gratification. It should be remembered also that the lot of the polygamous husband, even in societies in which polygamy is a working part of the social structure, is not always a happy one. Bohannan notes on this that "many men in polygamous societies look forward with only dread to the polygamous state. ${ }^{2}$

The importance of children for the lineage has given rise to many customs which encourage polygamy. There is a strong belief that a woman should not have another child before the first one is at least two years of age. During such time, the woman should have no sexual contacts with her husband in order to avoid pregnancy. In such a society, where the child is absolutely dependent on mother's milk, and where a child goes directly from weaning to adult food,

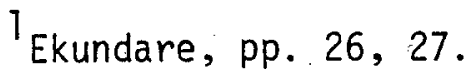

${ }^{2} \mathrm{P}$. Bohannan, Social Anthropology (New York: Holt, Rinehart, \& Winston, 1963), p. 108. 
nursing continues for two years or more. A child weaned too early does not survive. Therefore, this custom is of definite health benefit for the child but poses problems for the husband. During this time also, the woman often spends months away from her household to nurse her child in the village among her kinfolk. This custom encourages polygamy, In Upper Volta, a Mossi mother returns to her own patrilineal village during the lactation period. She "normally remains away, with the child about 2 to 3 years and only returns after the child can take care of himself. If she becomes pregnant shortly after she comes home, she aga in returns to her parents taking the baby and the young child with her." 1 Here then, a man is not only deprived sexually of his wife for long periods of time but also of her domestic services. A second wife is the usual way of solving such a problem.

In many traditional societies of West Africa, as for instance in the Bete tribe of the Ivory Coast, cohabitation between husband and wife is suspended after the wife passes child-bearing age. The African says she has become a "sister" to her husband, and many women at this time urge their husbands to take another wife.

The economic factor contributing to polygamy cannot be overlooked. A farmer may not be able to hire and pay workers to care for his farm, but he can always marry another woman. Nida notes that in a hoe culture, polygamy plays an important part, furnishing a substantial profit by their work and procuring children who

$1_{\text {Elliot }} P$. Skinner, Intergenerational Conflict among the Mossi, cited in Paul Bohannan and John Milton, Marriage, Family and Residence (New York: The National History Press, 1968), p. 239. 
contribute to elevate the status and prestige of the family in the society. 1

One must remember that with hard climate and unproductive agricultural methods, much labor is needed in order to make a living. Often the women themselves insist on the husbands taking a second wife.

In the predominantly rural economy, women often found the farm work, household chores, and long hours required to prepare family food a heavy burden physically. Since the system of hired hands was unknown, a co-wife was the natural solution for extra help. 2

Because of urbanization and modernization, the need for polygyny is decreasing. Wives are expensive in Western society. The number of men who could afford more than one wife is limited. So also in urban Africa. The possession of several wives in an urban setting can be financially ruinous. Here the average man who has to depend on his salary only cannot possibly support several women and their numerous children. But in rural areas, many wives may increase a man's wealth, social importance, reputation and authority. It increases his influence by connecting him with other families. It is a sign of valor, skill and wealth. Polygyny is associated with greatness, thus regarded as honorable and praiseworthy. Therefore, "the first wife of a Kaka man [Eastern Cameroun] will often urge him to take a second wife. Like any American wife, she wants to get ahead, move up the social ladder, and have life easier." 3

${ }^{1}$ For discussion see Eugene E. Nida, Customs and Cultures (New York: Harper \& Brothers, 1954), p. 105.

2 Marie-André, p. 93.

${ }^{3}$ Stephen A. Grunland and Marvin K. Mayers, Cultural Anthropology (Grand Rapids: Zondervan Publishing House, 1979), p. 162. 
Just as the real motivation for polygyny is poorly under-. stood in Western society, so also is its frequency greatly overestimated. It is true that a majority of the world's societies allow polygamy (about one-half of the world's societies practice polygyny as the preferred form of marriage, another third permits polygyny, and a little over one-eighth practices monogamy exclusively). Nevertheless, there are potentially more monogamous than polygamous households in the world. A11 men cannot afford to pay bride price for several women. As polygyny is profitable only in a rural setting, urban living and the increasing number of wage-earning workers tends to reduce the number of $i$ ts adherents. Among the Ashanti, for instance, although chiefs have many wives, it is "rare nowadays for commoners to have more than 3 wives at the same time. 80 percent of all married men have only one wife at a time." 1 . It is estimated that at the present time only 20 to 25 percent of African families are polygamous, and the number is decreasing as urban life and the breakup of the social order increases. Yet the philosophy behind the polygamous life style, with its emphasis on procreation as a duty to society, is deeply entrenched in the African mind. Wold has pointed out that although the "tight control of the tribes is weakening, missionaries would do well not to underestimate the social order as a current force in the lives of the people--even for those who by a11 outward appearance are rejecting the old order in favor of western ways. "2

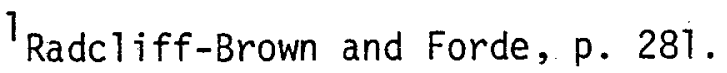

2Wold, p. 134. 
A polygamous man in an African society is definitely living within the norms of that society. This norm is not generally an expression of a depraved sexuality, it is rather a result of economical, social, and idealogical pressures operating within such a society.

\section{The Problem of Divorce in \\ African Society}

Husband-Wife Relationship

Divorce in an African society causes many of the same problems as in Western culture. There are, first, the emotional ties among father, mother, and children. Indeed, forced separation has created social turmoil within the families concerned and pain among the immediate family. The emotional problems caused by such separation have sometimes been poorly understood by missionaries who, observing African marriage built on group significance and procreation rather than on a personal union, have tended to minimize the traumatic effect of a separation. This impression is reinforced by a reticence to show affection between the African male and female, a reticence which is accentuated by marriage. Among the Baoule, for instance, any public show of affection between husband and wife is strictly taboo.

During a voyage, the man walks apart from his wife. If they are received in a village, he will hide himself in a corner when he eats with her, because he is exposing himself to ridicule by eating with a woman that is not of his lineage. Driven by this shame, the Baoule hides his genuine feelings under a rough exterior. 1

An extreme division between male and female spheres of

IGuerry, p. 19. 
interest and competence is generally characteristic of West African societies. A man must identify with his group. He loses dignity if he is too much in the presence of his wife or of the women of his homestead. Among the Gonjas "men and women do not eat together, only rarely work side by side, and are likely to spend their leisure with others of their own sex."1

In spite of their apparent indifference to each other, the feeling between the Gonja husband and wife "tends to be intense and personal, based on affection rather than obligation. . . While her loyalty to her brother (standing for her own lineage) was fiercely protective, emotionally she felt far more closely identified with her husband." 2 People of different cultures have different legitimate forms of conjugal love. To regard lightly the emotional pain involved in the separation of spouses on the ground that their marriage is only an arrangement is to do injustice to the partners involved.

\section{Problem of the Children}

Second, there is the problem of children. Here is encountered a situation far more complex than one finds in the Western society. In the African social setup, children belong not exclusively to their parents but to the lineage as a whole. Kirwin notes:

Children belonging to lineages are not under the private jurisdiction of their parents. They belong to the larger kinship group. . . This kind of recruitment has a number of beneficial effects. First, the children are not tied to the

${ }^{1}$ Esther N. Goody, Contexts of Kinship (Cambridge: University Press, 1973), p. 63.

$$
2 \text { Ibid., p. } 102 .
$$


personal fortunes of their parents. They are immediately located in a community which supports, cares for, and gives them identity. If a particular parent is emotionally unstable, sick, inadequate, there is the larger community helping to insure 'normal' development. There are no abandoned children or orphans, every child has a place in the community and is wanted. Secondly, no child is deprived of an inheritance as happens in Western societies. Every child's patrimony, e.g., land, cattle for marriage, is guaranteed by the lineage. 1

But in the event of a marital breakup, there are serious complications exactly because of this social system, the severity of which depends to a great extent on whether a society is matrilineal or patrilineal. In the matrilineal Ashanti society, the father has, in the event of a marital breakup, no legal rights to his children. Also in this matrilineal society, divorce, apart from the personal pain caused by the breakup, makes "little change in the domestic circumstances of a woman, or in her economical situation, nor does it affect her jural status, or that of her children. Though it may involve personal distress, it carries no moral stigma and no social penalties." 2 It is then the emotional relationship among wife, husband, and children which suffers along with the father's relationship to his children. For belonging to a matrilineal society, "an Ashanti father has no legal authority over his children. He cannot even compel them to live with him, or if he has divorced their mother, claim their custody as a right. ${ }^{3}$

It is, however, in patrilineal societies that the greatest social problems arise in case of marital separation (and the great

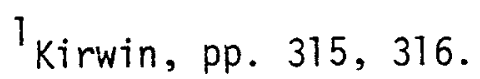

${ }^{2}$ Radcliff-Brown and Forde, p. 283.

3 Ibid., p. 268. 
majority of African societies are patrilineal). Here, perpetuation of the father's lineage through his children is of utmost importance. It is essential to the marriage. Hence children belong in perpetuum to the lineage of the father and the mother has no legal right over them. In this social system, "if a marriage is terminated by divorce, the woman has no legal way of retaining control over the children; she would have to leave them behind in the care of the husband's lineage . . . a powerful argument against divorce." 1 Radcliff-Brown and Forde, furthermore, note that

divorce is rare and difficult in those (tribes) organized on a system of marked father right. The frequency of divorce is an aspect of the durability of the marriage as such, which in turn is a function of the kinship structure. . . Marriage is for a woman's lifetime even if her husband dies. The marriage payment transfers the woman's procreative power absolutely to her husband's agnatic lineage for life, and therefore divorce is rare. 2

Thus in the Mossi patrilineage "men are accorded complete control over all their children." 3

In such societies, questions of paternity cannot be allowed to weaken the patrilineal system. In the Mossi tribe which "emphasizes social rather than biological parenthood, any child born to a man's wife is unquestionably his, whether he is at home or has been away for years. " ${ }^{4}$ Neither the mother nor the physical genitor has any right over them. If a man in such societies simply dismisses his wives without legal divorce (difficult to obtain in strongly patrilineal societies as it implies return of bride wealth),

Tirwin, p. 270.

${ }^{2}$ Radcliff-Brown and Forde, pp. 190, 192.

3 Bohannan, p. 238.

${ }^{4}$ Ibid., p. 239. 
the children she might later bear from another father would be claimed by the first husband's lineage, and she would have no legal control over them. Among the Bekweri, "a woman is in custom married to a man until the union is dissolved by death, or until the bride-wealth paid on her behalf has been returned. If a woman's husband is alive, his rights of paternity over any children born to her, even if she is living apart from him, is undisputed."1 In strongly patrilineal societies, then, the mother is the one who suffers the most, both socially and economically from divorce. The children retain their jural status in the husband's lineage and the husband retains legal control over his children. The mother loses her husband and her children, which belong to the husband's lineage. She might even lose any children she might bear after separation from her husband.

Since the rule of exogamy (to marry out of the group) usually is in force, a woman might be married far away from the natal village. The relationship with her own lineage is often severed in such cases, as upon marriage she comes under the absolute jurisdiction of her husband's lineage. In case of dismissal, she has nowhere to turn. Prostitution has often been the result of such severe cases.

The church policy on polygamy has stressed the father's responsibility of caring economically for his dismissed wives. Since customary laws might not permit him to divorce, he might still have to maintain his wives. This setup causes a string of social and

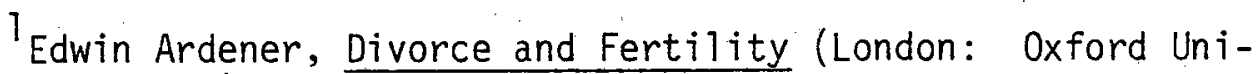
versity Press, 1962); p. 87 . 
emotional problems. He has one household in which he cohabits, and others which he must maintain socially and economically without cohabiting. Such a continued relationship increases the emotional problems both for himself and his wives.

Socially, he is still father of the children born before his conversion, but religiously they are illegitimate. These 'wives' are denied physical contact, so that these women who are socially mothers of the children are no longer physically wives. If there is still some affection, the 'mother' may commit 'adultery' with the 'husband' and in the requisite discipline of the 'monogamous' husband the church is involved in 'detective work! ."1

\section{Legal Problem}

The husband might even be forced by law to cohabit with his wives. Among the Yorubas, where customary law is highly developed, the wife can sue for a restitution order.

If for any reason the husband ceases to perform his obligations toward the wife, including cohabitation, the wife can petition for a restitution order--a restitution order could be made ordering the husband to resume full obligations toward the wife. . . Disobedience to the restitution order gives rise to a number of actions. Firstly, the act of disobedience may be brought to court, and the respondant may be heavily fined or punished in any way prescribed by the court. ${ }^{2}$

The church policy on polygamy seems to suggest that the polygamous marriage could be terminated at will from the side of the husband. This usually is not so. The total kinship group of each partner is involved in a marriage, and divorce is no private matter. The kinfolk on either side may refuse to reimburse or accept the bride-wealth, in which case, the divorce is not legally valid. For

\section{IAlan R. Tippet, "Polygamy as a Missionary Problem: The} Anthropological Issues, "Practical Anthropology 17 (March/April 1970): 77 .

$$
\text { 2Ekundare, p. } 53 .
$$


"the rule in many African societies is that if there is divorce, the marriage payment and the counter-payment (payment from wife's kin to husband) must be returned." 1 Such a system works as a powerful stabilizer on the marriage, which in case of marital frictions is arbitrated by the kinfolk or the village elders.

In many West African societies, the function of the village elders and lineage heads in marital matters is assumed by native courts. This is the case in the Bekweri tribe where "matrimonial causes respecting customary marriages are the concern of native courts, the members of which are expected to make rulings according to native law and custom. ${ }^{2}$

Among the Yorubas of Nigeria, the parties in marriage have no legal right to grant themselves a divorce. A petition for divorce to the customary court must be supported with adequate and reasonable grounds.

If the allegations on which the petition is based are not proved to the satisfaction of the court, a decree will be refused, and if the petitioner be the wife, she will be ordered to return to her husband, and if the husband, he will be ordered to accept the return of the wife, if she is already living apart from him. Failure to appear before the customary court when asked to do so by the proper authority is severely punished by fine/or imprisonment by the customary court. 3

If there are children in the marriage, the customary court always considers the welfare of the children in granting or withholding dissolution.

An adoptive Bye Law order which came into force in 1960 has stipulated that divorce should be refused if the woman is nursing a child under 3 years. . . The fact that there are

'Radcliff-Brown and Forde, p. 48.

${ }^{2}$ Ardener, p. 87.

3 Ekundare, pp. 43, 44. 
children of the marriage may be an absolute bar to dissolution if the children are too young or may be a discriminatory bar when the decision of the court rests solely on what is good for the children. 1

Among the Yoruba, the decision of the highest customary courts (that of the $0 \mathrm{ba}$ ) is final. If a petition is rejected, the same ground for divorce cannot be used a second time. A fresh petition can, however, be presented on new grounds.

It should be clear from the above discussion that in most cases a man is not free to dismiss his wives at will. That the State is not regulating the marriage does not mean that the marriage does not contain jural elements. In tribal societies, jural functions in marriage are most often assumed by the kinship groups in the context of 1 ineage and village. The establishment of native courts has further consolidated the matrimonial jural system in the emerging nationalistic States.

In many African States, a couple can choose whether to marry under custom or according to civil marriage 1aw. In Ghana, for instance, customary marriages are recognized as legal marriages by the State. A marriage can also be contracted in accordance with the Marriage Ordinance, Cap 127, of the Laws of Ghana. Marriage Ordinance does not permit polygamy. In Cameroun, both marriages are considered legal, but in this case the civil marriage offers no prohibition against polygamy. A man, then, might have contracted civil marriages with several wives. The difficult legal problems involved in separating such a family are obvious.

The concept that a polygamous man can simply dismiss his

1 Ibid., p. 45. 
wives as if the union is an irregular one represents, then, a basic misunderstanding of the African social and jural system.

\section{The Validity of Polygamous Marriage}

The Universality of the

Nuclear Family

Anthropologists point out that the universality of the family has generally been accepted as a sound hypothes is in anthroplogy. This theory confirmed by Murdoch's cross-cultural study of kinship asserts that "the 'nuclear family' is also universal and that marriage typically has four functions, namely sexual, economic, reproductive and educational." 1

Murdoch sees the reason for this universality in the fact that the functions served by the family are necessities for the survival of any society. The nuclear family, therefore, has an "immense social utility." ${ }^{2}$ Why? First, because "human sex needs are continuous and usually associated with emotional states, humans need more or less permanent sex partners." ${ }^{3}$ Second, because of "the long maturation period of the human infant. . . the human baby is totally helpless without nurture and protection of his parents or other adult humans." 4 Third, because "man is more than a biological creature. He is also a social, culture-bearing creature. Since man has few if any instincts, he must learn most of his behaviors. In

1Melford E. Spiro, "Is the Family Universal?" quoted in Paul Bohannan and John Middleton, Marriage, Family and Residence (New York: Holt, Rinehart \& Winston, 1968), p. 221 .

${ }^{2}$ Ibid.

${ }^{3}$ Grunlan and Mayers, p. $152 . \quad 4$ Ibid., p. 153. 
all cultures, a large part of this teaching job falls to the family. "I The nuclear family consists of a man, wife, and their immediate offspring. Malinowski asserts that marriage is a universal human institution. As such, it exhibits certain anthropological and judicial traits. These characteristics are also present in the African marriage institution. Vinogratoff emphasizes this point when he writes:

It can hardly be doubted that there are certain fundamental ideas which assert themselves in all forms of human marriage, and these fundamental ideas as generally understood by both jurists and anthropologists, appear to be inherent in the typical African conception of marriage.2

Juridical and Anthropological Criteria for Legal ilarriage

Malinowski notes that various forms of 1 icense observed in different societies (prenuptial liberty, relaxation of marriage bonds, ceremonial acts of sex, prostitution, and concubinage) are in no society regarded as a negation or substitution for marriage. ATthough prenuptial liberty is widely accepted in various societies, the occurrence of pregnancy under such circumstances is either considered a grave disgrace to the mother and a handicap to the child, or the child is wanted and expected as a condition for marriage which then is concluded. The Hausa, for instance, regard an illegitimate child with such a horror and aversion that "a child without a legal father is regarded as a major calamity, or a

I Ibid.

${ }^{2}$ Paul Vinogratoff, "Outline of Historical Juriprudence," quoted in Arthur Phillips, ed., Survey of African Marriage and Family Life (London: Oxford University Press, 1953), p. xii. 
monstrous perversion of the cause of nature." 1 In Northern Nigeria, conception without marriage is regarded as a very serious offense, and abortion is procured. With the kilba, unless the father is the promised husband, the child is killed.

A child born as a result of marital infidelity is often considered belonging to the legal husband whether he is the physiological father or not. Malinowski emphasizes that "the main sociological principles embodied in these rules and arrangements are that children should not be produced outside of the socially approved contract of marriage. $" 2$

Marriage, then, becomes not only the licensing of sexual intercourse, but the licensing of parenthood. The group of only mother and child is considered incomplete.

Through all these variations runs the rule that the father is indispensable for the full sociological status of the child, as well as of its mother, that the group consisting of a woman and her offspring is sociologically incomplete and illigitimate. The father, in other words, is necessary for the full legal status of the family. 3

Malinowski calls this rule the principle of legitimacy and asserts it as "universal sociological law":

In all human societies, a father is regarded as indispensable for each child, i.e., a husband for each mother. An illegitimate child--a child born out of wedlock--is an anomaly whether it be an outcast or an unclaimed asset. A group consisting of a woman and her children is a legally incomplete unit. Marriage thus appears to be an indispensable element in the family. 4

Even in extreme matriarchal societies where the wife remains at her mother's residence, this principle remains.

1L. P. Mair, "African Marriage and Social Change," in Arthur Phillips, ed., Survey of African Marriage and Family (London: Oxford University Press, 1953), p. 121.

$$
{ }^{2} \text { Malinowski, pp. 6,7. } \quad{ }^{3} \text { Ibid., p. 63. }{ }^{4} \text { Ibid., p. } 7 .
$$


The most important fact about such matriarchal conditions is that even here the principle of legitimacy holds good; that though the father is domestically and Economically almost superfluous, he is legally indispensable.?

Thus, in the matriarchal Ashanti society, "a person is not incorporated as a member of his lineage until his matrilineal status is ritually recognized by the bestowal of complementary patrifiliation. "2

The principle of legitimacy also was the basis for the Roman marriage law, which provided the foundation for Western marriage law.

Illegitimacy usually means the status of a person who has no jurally or legally recognized pater. . . Roman law defined a person illegitimate if he has no legal father, as shown by the legal marriage of his parents. 3

The legal marriage of the parents then was the criteria by which the legitimacy of the children was judged. Therefare, the definition of marriage from an anthropological point of view has been stated as "a union between a man and a woman such that children born to the woman are recognized legitimate offspring of both parents. " 4

In human marriages, then, the legitimacy of the children born to the union is a criterion of its validity.

One sees in the discussion of African kinship that the principle of legitimacy is important in African traditional society because it is marriage which legitimizes the offspring and determines to which lineage the child belongs, to the father's in patrilineal societies, to the mother's in a matrilineal one. In fact,

$$
\text { I'Ibid., p. 13. 2Fortes, p. } 199 . \quad 3 \text { Ibid., p. } 258 .
$$

${ }^{4}$ From Notes and Queries quoted in Kathleen Gough, The Nayars and the Definition of Marriage, in Paul Bohannan and John Middleton, Marriage, Family and Residence (New York: Natural History Press, 1968), p. 49. 
among the Yoruba of Nigeria, "legitimacy proceedings in customary courts are sometimes employed for obtaining a declaration of the validity of the marriage." 1

\section{Marriage--A Legal Contract}

Marriage implies more than a mere licensing of sexual intercourse. Westermarcknotes that "if concubinage is used as a term not for a mere liaison of some duration but for a relation recognized by custom or law, I think it anyhow should be restricted to relations that only imply sexual licence, whereas marriage is something more than a regular sexual relation between man and woman. "2

In all societies, marriage entails a 'legal' contract.

Marriage is never a mere co-habitation, and in no society are two people of different sex allowed to share life in common and produce children without having the approval of the community. This is obtained by going through the legal and ritual formalities which constitute the act of marriage, by accepting in this the obligations which are entailed in marriage, and the privileges which it gives, and by later on to submit to the consequences of the union as regard children. . . . The way in which people have to co-habit and work together is stipulated by tribal 1aw. 3

Thus among the Bekweri, for instance, women in concubinage and prostitution would usually live outside the village limit, even if their partners or clients, were Bekweri. "Fellow tribesmen frequently referred to both concubinage and prostitution in a derogatory way by the same word: Akpala. The tendency for the woman to move from one type of illegitimate union to another is marked. "4

In Western marriages, it is the State that confers legality on a marriage. In tribal societies, the State is rarely thus concerned.
$1_{\text {Ekundare, p. } 64 .}$
2 Westermarck, p. 35.
3 Mal inowski, p. 16.
${ }^{4}$ Ardener, p. 22. 
How then is one to distinguish a legal marriage? Radcliff-Brown and Forde give the following answer:

A legal marriage, by which the children that will be born are given definite 'legitimate' status in the society, requires a series of transactions and formalities in which the two bodies of kin, those of the husband and those of the wife are involved. In most African marriages, as in early English marriages, the making of a payment of goods or services by the bridegroom to the bride's, kin is an essential part of the establishment of 'legality'.?

However, he warns against considering such transactions as purchase. In 1917 the Supreme Court of Kenya ruled that a marriage so contracted according to native custom of wife purchase was not a marriage. Radcliff-Brown and Forde explain that this decision of the Court was the result of ignorance, "which may once have been excusable, but is no longer, or of blind prejudice, which is never excusable in those governing an African people. ${ }^{2}$ As noted earlier, bride wealth or lobola is typical of the patrilineal groups in Africa but may have various functions in different societies. It can have a symbolic function. First, the bride wealth is a form of compensation to the family who suffers a loss when the bride leaves her immediate kin to join the kin of her husband. Radcliff-Brown and Forde note:

This aspect of marriage is very frequently given symbolic expression in the simulated hostility between the two bodies of kin at the marriage ceremony, or by the pretence of taking the bride by force (the so called 'capture of the bride'). Either the bride herself or her kin, or both, are expected to make a show of resistance at her removal. 3

Second, bride wealth gives the husband and his kin certain rights in relation to the wife and her children. Here, Price notes that

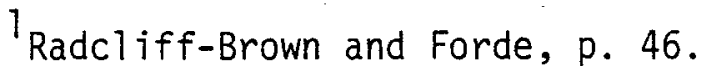

2 Ibid., p. 47.

${ }^{3}$ Ibid., p. 46.
} 
the bride price is a form of recompense to the wife's kin for the children she would bear and who would reinforce the husband's lineage, and . . . since claim for repayment is based on the wife's default, not simply on any kind of breakdown, their interest is both in discouraging her from misbehaviour and defending her against mere aspersion. The bride price too is security for her well-being once she has left her family group.

In regard to Dahomean marriages, Laura Bohannan writes:

It has become evident that the full bride-wealth marks transfer of ritual and jural authority over a woman and mother: that is, there are transferral rights in a woman as wife, uxor; and mother genetrix $i-e$, rights (for the husband lineage) in her children onçe born are held by virtue of holding rights in genetricem. ${ }^{2}$

Third, bride wealth may constitute the symbol of an alliance between the two families. It becomes, then, a form of covenant token.

Marriage establishes a bond not only between a man and a woman but between the families to which they belong. Bride price or bride wealth was made over by the family of the man to the family of the woman. This bride price, it is generally agreed, was initially a token of the solemnity of the undertaking and of the closeness of the link established between the two families. The giving and receiving of the token sealed the contract. 3

Matrilineal societies do not have bride wealth. They have a system of dowry. Symbolic gifts may conclude the marriage contract. Thus, in Ashanti marriage, "the marriage is made legal by payment known as tiri nsa or aseda (thanks-money): the latter term used of the gift which according to Ashanti custom is made at the conclusion of any contract." 4 Among the patrilineal Yoruba the following steps are taken in order to conclude the contract:

TPrice, p. 15.

2Laura Bohannan, "Dahomean Marriage," in Paul Bohannan and John Middleton, eds., Marriage, Family and Residence, p. 94.

${ }^{3}$ A1T-African Seminar on the Christian Home and Family Life (Lauzanne: Imprimerie La Concorde, 1963), p. 16.

${ }^{4}$ Lucy Mair, African Marriage and Social Change (London: Frank Cass and Co. Ltd., 1969), p. 129. 
The contract to marry is called Isihum meaning 'formal consent'. . . . The contract to marry is made when in consideration for the consent of the girl's parents and family, the boy pays the consent fee called Ijohun meaning agreement. . . There is a binding promise to marry, if the parents and the family of the girl consent in consideration for the 'consent fee' from the boy. A breach of this promise by either party is actionable in a customary court. . . The contract of marriage which is embodied in the 'anan' or 'dowry' is the last of the major contracts leading to the actual marriage ceremony. . . The significance of the 'anan', is that, at least the boy and his family can plan the wedding with the consent of the girl's family. ... In all dowries whether from a poor or rich man, the following must be included: 40 kolas, which are regarded as emblem of security and nobility; honey as a symbol of happiness; alligator pepper, symbol of fruitfulness; and drinkables, for the entertainment of those present at the ceremony of the contract. ${ }^{2}$

Bride wealth then is a transaction of utmost importance in African marriage. It establishes the legality of the union and acts as a stabilizing factor.

It (bride price) gives a sense of security to the bride, it gives her a sense of dignity and of being wanted. It establishes her family's interest in her. It gives her security from the husband's anger or from other abuses; she can go home in the knowledge that her husband is certain to seek her out and that he will have to deal with her father and her brothers who are likely to demand payment if they can establish that there was a lack of fair play. But it also gives the husband the knowledge that the children are his no matter what happens (in partrilineal society). It establishes him in control of his house and homestead and gives final say in many important decisions regarding the children, their initiation, their marriage, ceremonies, etc. ${ }^{3}$

However, it is important to point out that in many places under modern development, the custom of bride wealth has degenerated into a money-making proposition. This, as well as other practices which have developed in response to pressures of social and economical

1Dowry here is a misnomer; the reference is to bride wealth. 2Ekundare, pp. 14, 15, 18, 19, 20.

${ }^{3}$ B. Whooly, Marriage in Africa, cited in T. D. Verryn, ed., Church and Marriage in Modern Africa (Johannesberg, South Africa: Zenith Printers, 1975), pp. 312, 313. 
change, is very unfortunate. The point should not be forgotten, however, that one cannot dismiss the validity of a custom just because it is being abused.

In most patrilineal societies of Africa bride wealth was and is still considered the outward sign of the legality of the marriage. This is certainly true among the Yorubas of Nigeria. If bride wealth has not been paid, there is no contract of marriage and hence there can be no marriage ceremony whether validly or invalidly performed. On the other hand, if bride wealth has been paid, an invalid ceremony does not make the marriage void in customary court. The bride wealth constitutes the legal contract of marriage. Ekundare notes that "Except in cases where payment of the dowry" has been waived, a marriage alledged to take place without the payment of the dowry is null and void ab initia (Ajake versus Yesufu Ogulna). ${ }^{2}$ The African marriage, thus, fulfills the requirements of marriage as constituting a legal contract.

\section{Marriage--Publicity and Ceremony}

In all human societies, marriage ceremony has a religious and ceremonial aspect. Malinowski notes that it is not only the Christian religion which stresses the sanctity of the marriage ties. In all societies marriage is concluded by ritual enactment.

Also, the publicity of the union is a very important feature in marriage. As pointed out by Malinowski:

\footnotetext{
${ }^{1}$ Dowry refers here to bride wealth.

${ }^{2}$ Ekundare, p. 59.
} 
The most general social object of a wedding rite is "to give publicity to the union." By this the legal as well as the religious sanction of the union is established. The contract is made binding in that a 11 members of the community bear witness to it, it is hallowed in that the two mates solemnly and openly declare before man, God, or other spiritual powers that they belong to each other. 1

Ritual and publicity are certainly important parts of the African marriage institution. Among the Yorubas, for instance, one finds that, except in unusual circumstances, a proper marriage ceremony must follow the bride wealth before the marriage can be deemed fully legal. On the day of the ceremony, the girl is blessed by her parents in the presence of relatives and very close friends. Al1 day long, salutations are passed between the family of the man and the family of the girl. The girl may be escorted to her husband's home either in the early hours of the morning--about 4 or 5 a.m.--or in the night--about 8 to 9 p.m. or later. These times are customary to enable as many members of the bride's family as possible to be present at her final blessing ceremony before she departs for the bridegroom's house. Also, members of the family of the bridegroom are expected to witness the arrival of the bride and the final "handing over" ceremony between the escort of the bride and the representatives of the bridegroom.

The girl is usually escorted by women of her family . . and she is then handed over to either the first wife ('Iyale') of the husband, if he is already married, or otherwise to the mother of the husband acting in his behalf. The girl's feet must be washed at the front door by the person to whom she was handed and she must be lifted, not by the husband, across from the door entrance into the house. A few of the women who escorted the girl must wait in a specially prepared room until after the consummation of the marriage. . . . On the second or third day after the ceremony, the parents of the bride send her belongings

$$
\text { 1Malinowski, p. } 23 .
$$


after her, personal belongings as well as useful utensils. She is therefore adequately equipped to perform wifely duties. 1

Thus, it has been established that African marriage entails a legal contract securing the legitimacy of the offspring. It has ritual and ceremonial aspects where the publicity of the union forms an important part.

Similarities between Israelite and African Marriage Institutions

One may note here the many similarities between the Israelite marriage institution and that of the Africans. The kinship structure and extended family are important in both. In regard to the Israelite family structure, De Vaux notes that "the members of the family in this wider sense had an obligation to help and protect one another. . . The firmness of these family ties was an inheritance from tribal organization." 2 . It is important to mention here that the Israelite kinship structure was patrilineal and practiced clan endogamy while the African patrilineal societies are mostly clan exogamous.

In both institutions the unmarried woman was under the jurisdiction of the father. When she married, she came under the authority of the husband. In the Israelite society the Mohar was a present either in the form of a sum of money or its equivalent in kind to the bride's father. "Mohar is a compensation to the father for the loss of his daughter as well as the means of providing her

'Ekundare, pp. 22, 23.

${ }^{2}$ Roland De Vaux, Ancient Israel. Social Institutions, vol. 1 (New York: McGraw Hil1 Book Co., 1961), pp. 21, 22. 
with certain necessities." In the thinking of the Israelites, mohar seemed to have been not so much a price paid for the woman as a compensation given to the family, establishing the husband's jurisdiction over the woman.

The Israelite marriage was also arranged by the family. Neither the girl nor, often, the youth was consulted. Abraham sent his servant to choose a wife for Isaac, and the servant arranged the contract with Rebecca's brother (Gen 24:33-54). Hagar took a wife for Ishmael (Gen $21: 22$ ) and Judah arranged his son's marriage (Gen $38: 6)$.

The levirate was practiced in Israel. "According to the law of Deuteronomy 25:5-10, if brothers 1 ive together and one of them dies without issue, one of the surviving brothers takes his widow to wife and the first-born of this new marriage is regarded in law as the son of the deceased. ${ }^{2}$

There were two stages to the Jewish marriage--betrothal (kiddushin) and marriage proper (huppah). The betrothal was the legally binding promise of marriage (Deut 20:7). The betrothed was regarded as though she was already married. Any other man who violated her was stoned to death as an adulterer. Huppah was the actual wedding ceremony or bringing home the bride. Here

the chief ceremony was the entry of the bride into the bridegroom's house. . . A Accompanied by his friends with tambourines and $a$ band, they went to the bride's house where the wedding ceremony was to start. . . Escorted by her companions, the

TMerril C. Tenney, The Zondervan Pictorial Encyclopedia of the Bible, vol. 4 (Grand Rapids: Zondervan Publishing House, 1975), p. 96.

${ }^{2}$ De Vaux, p. 37 
bride was led to the home of the bridegroom. . . . Big feasts were prepared in the house of the bride and sometimes in the bridegroom's parents house. At the close of the feast the bride was conducted by her parents to the nuptial chamber (Judges 15:1). . . There were no marriage festivities for concubines.1

The stress in Israeli marriages was on procreation (Ps 127:

3-5). Childiessness was considered an affliction. "It is the cause of Sarah's despairing laughter, Hannah's silent prayer, Rachel's passionate alternative of children or death, and Elizabeth's cry that God had taken away her reproach (Luke 1:25)." ${ }^{2}$ And this emphasis on procreation often led to polygamy.

Desire for a large family to inherit the father's goods and carry on the name, coupled with the sterility of some women and probably a high infant mortality, are among the chief causes of polygamy in the $01 d$ Testament. 3

In pointing out the similarities between the Israelite marriage custom and that of the traditional African, one observation must be made. Since one does not question the validity of the marriage in Israel although it did not follow the pattern that is usual in Western society, or because it did not exclude polygamy, African customary marriage must be considered in the same light. Indeed, the legality of the polygamous form of marriage can be dismissed neither on anthropological grounds nor according to biblical custom. For polygamous marriages conform to both anthropological and jural criteria for valid marriages. Malinowski explains that monogamy is the underlying pattern for a polygamous marriage:

\section{Tenney, p. 96.}

${ }^{2}$ T. D. Verryn, ed., Church and Marriage in Modern Africa (Johannesburg: Zenith Printers, 1975), p. 173.

3 Geoffrey Parrinder, The Bible and Polygamy (London: SPCK, 1950), p. 23. 
In reality it (polygamy) is not so much a form of marriage distinct from monogamy as rather a multiple monogamy. It is always in fact the repetition of a marriage contract, entered individually with each wife, establishing an individual relationship between the man and each of his consorts... . As a rule each relationship is little affected legally or economically by the others. 1

The polygamous unions in African societies constitute a valid marriage as seen by the fact that the principle of legitimacy remains intact. Children of polygamous unions obtain full legitimate status in their society and are accordingly incorporated in their proper lineages. The marriage is based on a legal contract through the passing of bride-wealth which must (in most cases) be refunded upon divorce. Furthermore, the marriage is accompanied by the ceremony and publicity connected with marriages in a given tribe.

In the biblical record, one finds that a polygamous marriage was considered valid.

Were Jacob and Moses adulterous? The 0.T. gives not the slightest indication that it so considered them. Did the bill of divorce which Moses gave apply only to monogamous or also to polygamous marriage? Among the many forms of sexual sins and abnormal sexual acts condemned in the 0.T., polygamy is not mentioned.2

Furthermore, severe penalties were prescribed for adultery in the OT (Lev 20:10, Deut 22:23; Exod 22:16). But there are no indications that such penalties were prescribed for polygamy. This fact would indicate that in the Bible there is a clear distinction between polygamy and adultery. Neither did the prophets equate adultery and polygamy. Holst ascertains that "it is certain that

$$
\begin{aligned}
& \text { 1Malinowski, pp. 31, 32. } \\
& { }^{2} \text { Harry Boer, "Polygamy," Frontier } 2 \text { (Winter 1968-69):25. }
\end{aligned}
$$


Ezekiel, who was primarily interested in calling people to repentance, did not consider polygamy equivalent to adultery. Otherwise he would not have used an allegory which makes God an adulterer (Eze 23:1-4)."1 The writings of E. G. White never refer to polygamy as adultery. Rather it is designated as a perversion of the marriage institution. ${ }^{2}$ It may be asserted here, then, that according to jural/ anthropological criteria, the African customary marriage, whether monogamous or polygamous, must be considered as a valid marriage. Hastings confirms this statement when he says:

What then is to be said of polygamy? Not undoubtediy, that it is comparable with adultery. It is not. It is in itself essentially a responsible, caring, legal public and enduring relationship, and it is accepted as such in the judgement of peoples in many parts of the world. It is marriage. The evidence of the 01d Testament is clear as to this. 3

\section{Objections Raised against the Validity of the African Customary Marriage}

It has been concluded that according to anthropological and jural criteria, African customary marriage (monogamous or polygamous) constitutes a valid marriage. Furthermore, the biblical record does not prevent one from drawing such a conclusion. Objections to the validity of the customary marriage have, however, been raised on the grounds explored in the following section.

TRobert Holst, "Polygamy and the Bible," International Review of Missions 56/222 (Apri1 1967):209, 210.

${ }^{2}$ See Ellen G. White, Patriarchs and Prophets (Mountain View: Pacific Press Pub. Assoc., 1958), p. 338.

${ }^{3}$ Adrian Hastings, Christian Marriage in Africa (London: William Clowes and Sons, 1973), pp. 76, 77. 
Unity and Personal Relationship

It has been argued that African marriage, sealed by family arrangement and having procreation as its chief intention is lacking in the unity and personal relationship which characterize a Christian marriage. It cannot therefore be regarded as a marriage according to Christian principles. The latter demands a more elevated form of marriage relationship and family life.

It is true that personal attraction between spouses is of minor importance in African eyes. According to Radcliff-Brown and Forde, "The African does not think of marriage as a union based on romantic love, although beauty as well as character and health are sought in the choice of a wife." 1

In Western society, marriage is based on romantic love and affects primarily two individuals. This, however, is a rather recent development. In "Anglo-Saxon England, a marriage, the legal union of man and wife, was a compact entered into by two bodies of kin. . . . The 'giving away' of the bride is a survival of something which at one time was the most important feature of the ceremonial marriage. "2

If Western marriages are considered to concern mainly the nuclear family, and depend on personal choice and romantic love, then ". . . very many European marriages in the past would have been classified as 'African' rather than 'Western', as also would those of Ancient Israel." ${ }^{3}$. The presence of such feelings has never

$$
\begin{aligned}
& 1_{\text {Radcliff-Brown and Forde, p. } 46 .} \\
& { }^{2} \text { Ibid., p. } 45 . \\
& \text { 3Hastings, p. } 30 .
\end{aligned}
$$


been considered a criterion for the validity of Western marriages. Why then apply requirements to non-Western marriage institutions that are not willingly applied to one's own?

The problem with this objection is that the quality of the marriage is used as a criterion for its validity. Such a criterion is highly subjective. Who would dare be the judge in such a case? If the deeper sense of personal union and love is lacking (which might be the case in both Occidental and African marriages), these are ideals which in a Christian marriage are developed within the existing bonds, through the sanctifying power of the Holy Spirit (see chapter 3 ).

The Question of Indissolubility

Another objection raised has centered around the view that some forms of African customary marriage may be easity dissolved and do not convey adequate assurance of stability--that the married partners, in fact, do not have the intention of contracting an exclusive life-long union. It is quite true that in many tribes a marriage can be easily dissolved. It has been noted earlier that marriages in matrilineal societies tend to be unstable. In contrast, most patrilineal societies have very stable marriages. Marriage here is often even considered to outlast death, as seen in the leviratic custom. Rites persisting in some societies seem to indicate that in former times marriage was indissoluble. One of the bases of the Yoruba matrimonial law is to keep a marriage alive at a 11 times and under a 17 conditions. Ekundare explains that "under customary law, marriage was almost always indissoluble as it was 
looked upon as a permanent social and spiritual bond between man and wife on the one hand and their respective families on the other hand." 1

It has also been noted that matrilineal societies tend to. have unstable marriages. But even here there are variations in matters of stability. Among the matrilineal Ashanti communities of Ghana, "parents on both sides have duty to keep the marriage going. All marital leakages likely to flood or demolish the structure of a community are quickly blocked." ${ }^{2}$ Phillips notes that "it would seem that no very definite conclusions can be drawn from a comparison between African and European marriage in the matter of dissolubility." ${ }^{3}$ It is not only Christianity which emphasizes the sanctity of the marriage bond. Generally speaking, dissolution of marriage is regarded as an ill to be avoided in all human societies. Therefore, "Christians do no good service either to the humanity or to their faith by derogating from the integrity of customary or civil marriages--by elevating, so to speak, into a mark of characteristic what is only a corruption due to $\sin . " 4$

The American marriage, at the present time, presents no example for the ideal of indissolubility, as one in every four marriages ends in divorce. Marriage laws have been changing to accommodate a more liberal view toward divorce. This fact does not

$1_{\text {Ekundare, pp. } 43,44 .}$

${ }^{2}$ J. V. Tufuo and C. E. Donkor, Ashantis of Ghana: People with a Sout (Accra: Anowuo Educational Publications, 1969), p. 43.

$3_{\text {Phillips, p. xv. }}$

${ }^{4}$ All-African Seminar, p. 14. 
lead one to question the validity of the American marriage institution. Here again one must beware of applying criteria to other cultures and institutions that one would not be willing to apply to one's own.

\section{No Legal Sanctions Safeguarding Monogamy}

Objections to the validity of African forms of marriage have also centered in the fact that there are ro legal sanctions safeguarding monogamy. Therefore, during the union of two spouses there is "no legal impediment to the contracting of another marriage by the husband." 1 The objection goes that the African marriage institution as a whole is potentially polygamous and cannot be considered a valid institution according to Christian principles. But this argument is open to questioning. "Apart from the fact that the relevant penal provisions of marriage laws are so often a dead letter as far as the Africans are concerned, many missionaries would disclaim any desire to invoke the aid of the temporal power for the enforcement of Christian standards of conduct."2 Hastings argues that all natural marriages are potentially polygamous and also potentially monogamous; therefore the validity of a customary marriage should not be denied.

The early Christians married according to the customary forms of marriage found in their respective countries. In Greece and Rome, monogamy was safeguarded by legal provision, but among the Jews and in other countries where the Gospel was entering this was not so. Nevertheless, no objections have been raised against the legality of the Jewish marriage institution on the ground that it was potentially polygamous.

$$
{ }^{1} \text { Phillips, p. xiv. } \quad \text { 2Ibid., p. xxxii. }
$$


Marriage not Performed before Church or State

Doubts about African customary marriage have also sprung from the fact that such marriages are not performed before a representative of the church or registered by the State.

This argument shows the force and the subtlety of the ethnocentric predicament. Marriage, as it developed in tribal societies, did not have recourse to the church. Also, since kinship and State structure were interrelated, the tribe had the power to regulate marital matters according to custom. Nevertheless, the Westerner tends to judge this institution by reference to its Occidental counterpart. Furthermore the modern English idea of marriage is a product of a particular social development resulting in the fact that a wedding is an event concerning both the partners and the State. The State alone legalizes the union and has the power to dissolve it by divorce. The consent of the parents is required only for minors. One should also remember that the Western ideas and forms of marriage have undergone great changes through the centuries and are still in the process of change.

Not only are marriage and ideas about marriage in England and America the product of a recent, special complex development, but there is good evidence that they are still changing. The demand for greater freedom of divorce is one indication of this. Yet it is clear that despite all this, some people take the twentieth-century English marriage as a standard of civilized marriage with which to compare African marriage. 1

It is unfair to assume that the onty effective and acceptable form of marriage is that practiced in one's own society. Setting up one's own marriage institution as a criterion by which to judge marriages

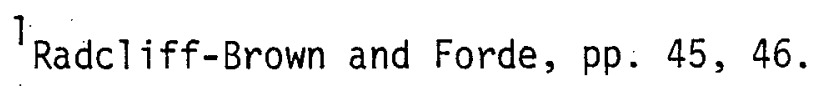


in other cultures is an example of cultural absolutism. Insisting that the forms and rituals of one's own institution are the onty expressions of Christian marriage is to confuse adiaphora with the essentials of the Gospel. As pointed out in chapter one, no single culture is the perfect expression of God's will. All human institutions are under the bondage of sin, and Occidental marriage institutions are no exception. The essence of Christian marriage, then, must not be confused with a particular, cultural expression.

There has never been a particular form of Christian marriage. In ancient Israel, marital matters were regulated according to custom.

It is reported that the early Christians married according to the custom of the country to which they belonged.

According to the evidence of a contemporary letter, the Epistula ad Diognetem, Christian marriage was much the same as that of pagans. As a general rule, Christians were bound to conform in this and in similar matters to the pattern of life of their environment. The synod of Elvira, held about the year 306, also accepted as its point of departure that the marriages of baptized Christians were celebrated like those of unbaptized pagans. The church simply accepted the subjection of the members to Roman legislature, and matrimonial cases were also brought before the civil law courts. . . I In the case of marriages between two Christians, clerical intervention was regarded as superfluous. 1

Marriages, then, contracted according to the prevailing social customs were considered valid; only clandestine marriages were forbidden. The stress here was that the fact of being married had to be officially controllable.

Historical development of the Western marriage form. Hastings notes that the priestly blessings of marriage became more regular from

'E. 0. P. Schil Tebeeckx, Marriage--Human Reality and Saving Mystery (New York: Sheed and Ward, 1965), pp. 244, 245. 
the fourth century on, but was considered not as the wedding ceremony but rather as a post-wedding blessing.

There is no suggestion from this period that the performance of such liturgical ceremonies was considered to be absolutely necessary for the validity of the marriage, al though the church did lay evermore insistence upon the moral duty of Christians to marry in this way before the priest. But the validity of marriage depended upon the consent of those taking part and this could at least as well be manifested through the customary and traditional marriage ceremonies of the people involved. These customary ceremonies may not have included the precise formulas which we have since come to associate with the making of a marriage, but rather like African customary marriage, they signified the meaning of the whole of all concerned, the pronunciation of the blessings and the transfer of the bride.?

Hastings, further, stresses that the insistence on church weddings came as a result of breakdown of the customary marriage. This was caused by the growing influence of the church in jurisdiction over marital matters and by changes in society. As a result of this situation, clandestineness in marriage developed. Marriage became more and more ecclesiastical in order to counteract this developing clandestineness. It became the only alternative as no 'civil marriage' was yet available. The increased ecclesiastical emphasis on marriage, then, developed in response to the need of safeguarding the publicity of the marriage and counteracting clandestineness resulting from the breakdown of the customary marriage institution. The final result of this development was the insistance that only marriages carried out before the priest and two witnesses were valid unions. The Council of Trent in its Tametsi decree of 1563 achieved just this. Church marriage was not justified on theological grounds, but "its justification was that marriage must be public and there was now in many places no viable alternative to ecclesiastical marriage. ${ }^{2}$ 
However, this ecclesiastical development in marriage was not readily accepted in England. But as clandestineness became evident in marital matters, the Hardwick's Marriage Act instituted in 1753 designated oniy church marriages as valid unions.

Customary marriages continued as common law marriages into the nineteenth and twentieth centuries, with the church attempting to stamp out these survivals of customary marriages. When the missionaries arrived in Africa, they adopted the same negative attitude toward African customary marriages, questioning their validity. On this continent, however, the customary marriage was still in its full strength, fully public and exhibiting all the criteria for validity.

With the rising power of the secular State, marriage matters gradualiy came under its jurisdiction. "At the end of the Middle Ages, there came the struggle for power between Church and State, in which the State was, in Protestant countries, victorious. Marriage then came under State control."2

In most West African societies, on the other hand, the customary marriage has full legal status. It was accepted as such by colonial powers.

- . By virtue of the recognition accorded by colonial governments to native customary law, marriage under that law not on ly possesses full legal validity, but is from the secular point of view the form of marriage primarily and most obviously applicable to the vast majority of Africans, 3

${ }^{1}$ See Hastings for discussion pp. 68, 69.

${ }^{2}$ Radcliff-Brown and Forde, p. 45.

3 Phillips, p. xxx. 
The new nationalistic and modern states of Africa have interferred little with the customary marriages. Whatever attempts have been made, have been, on the whole, failures as the majorjty of West Africans continue to marry according to custom. In the Bakweri population of Cameroun a study showed that only 1.4 percent of the population polled had contracted civil or church marriages compared to 79 percent married according to custom (concubinage 9.5 percent, casual 7.6 percent, and inherited 2.5 percent accounted for the rest of the percentage). ${ }^{1}$

With few exceptions, customary marriage is considered the only valid form of marriage by the traditional Africans. Church marriage remains an addition or an appendage.

Christians do not get married in church without the traditional ritual and feasts. In fact, as I have pointed out, the marriage in church is not what makes a couple man and wife for the community. . . The Africans concerned cannot conceive of marriage except in the form they have it.2

Here, we can state that in many African societies, church and civil marriages without a customary "legality" of the bride price would run the risk of being considered not as valid marriages, but as a sort of concubinage. If this is so, then the customary marriage ought to be considered valid by the Christian missions. An ambiguous attitude here on the part of the missions can only weaken the marriage institution and contribute to moral instability, i.e., the exact opposite of the Christian ideal. Furthermore, considering the example of the early Christian Church, one cannot deny the validity of the

${ }^{1}$ For statistics see Ardener, p. 30.

2 Kenneth Hughes, "The Church and Marriage in Africa," The Christian Century 82/7 (February 12, 1965):306. 
African customary unions on the ground that they are not performed by a representative of the church. Theoretically, this has been the view of the Protestant Church.

We in the Seminar adhere to the age-old teaching of the Church that marriage is God's ordinance for man "from the beginning of creation" (Mark 10:16), and that a union properly entered into with ful1 consent, by a man and a woman competent to marry one another, and publically recognized in the society in which they live, is a valid marriage in its own right; and we hold that the church, if it is to be true to its own theology, must recognize it as such. 1

Catholic-Protestant marriage concepts. There is, in theory, a sharp difference between the Catholic and Protestant views of customary marriage. The Roman Catholic Church has gone beyond the position taken by the Council of Trent by considering marriage as a sacrament, stressing that marriage ." . . cannot be identified with any form of solemnization prescribed by civil authority, and all such forms are equally unacceptable to the church--the only exception being where the civil authority grants unqualified recognition to canon law." 2

Consistent with this view, converts are required to marry under canon law. There is no contradiction between the Catholic view of the indissolubility of marriage and the dismissal of a polygamist wife prior to baptism, as natural marriages are considered in the eyes of the church on a different level. There is also the presumption inherited from the Roman marriage institution that the first marriage had the greatest claim to validity. In consequence, a11 other wives are considered somewhat as concubines. Furthermore,

p. 13.

'All-African Seminar on the Christian Home and Family Life,

${ }^{2}$ phillips, p. xxix. 
the canonical regulation known as the "privilege of faith" based on the Petrine power to bind and to loose authorizes the dissolution of marriages previously recognized as valid. This dissolution is done "in favor of the faith" of the would be Christian spouse. The Protestant view on the other hand, considers marriage as fundamentally a civil contract with no basic differentiation of Christian and natural marriage. This view plainly involves insistence on the duty of Christians to observe the civil law of marriage. Furthermore, Protestants have consistently rejected the Catholic view that marriage between baptized persons and performed according to canon law is different from that of the unbaptized. Protestants have always maintained that the Catholic (Tridentine) doctrine "that mutual consent by two baptized persons of itself involves the creation of an invisible vinculum or bond (in contrast to the union of the unbaptized) is not biblical, nor is it a tradition of the universal church, nor does it accord with the empirical evidence of matrimonial breakdown." 1

The criterion for a valid marriage, then, according to the example of the early church and Protestant tradition, is that

theologically, it is sufficient that if two Christians willingly and knowingly undergo a recognized form of marriage, then they are married; this is true even if there has been no specific reference in it to indissolubility or monogamy at least so long as neither of these is explicitly excluded.?

The church blessing of a customary marriage then does not enhance the validity of such marriage.

p. 37.

1Marriage, Divorce, and the Church (London: SPCK, 1972), ${ }^{2}$ Hastings, p. 71 . 
We cannot, consistently with our theology, pretend to marry them again, nor should we countenance any rite or ceremony which gives the mistaken impression that we do. Natural piety may demand some "blessing" by the church of this marriage newly incorporated into Christ. . . . Only it should be made clear. that the church is not "marrying them again"; the original bond remains, caught up now into the New Covenant and so partaking of the indissolubility of the Covenants of God. 1

The SDA church, within the West African Union working policy, ${ }^{2}$ recognizes African customary marriage whenever such marriage is recognized as valid by local government. However, a church blessing upon a11 marriages is recommended.

In theory, the Protestant position on marriage is clear; in practice, however, much ambiguity has evolved from the church's attitude toward customary marriage. This ambiguous attitude is seen in the seeming ease with which Protestant missions have insisted that prior to baptism the polygamist must dismiss his wives, although, consistent with Protestant theology, such dismissal constitutes divorce.

$$
\frac{\text { Conclusion on Validity of }}{\text { Polygamous Marriage }}
$$

The Lambeth Conference referred to polygamous marriages as alliances, implying somehow that a marriage that is not monogamous is not marriage at al1. But is this defensible? Both on anthropological and jural grounds the polygamous union may be considered a legal marriage. It is a public state, based on a valid contract, involving life-long responsibility and obligations, and is recognized p. 13.

\section{'All-African Seminar on the Christian Home and Family,}

${ }^{2}$ See West African Union Policies (Accra: Advent Press, $1972)$, p. 58. 
as valid marriage in the societies where it is practiced. But if polygamy is marriage, separation is divorce. The church then must face up to the fact that in requiring a polygamist to dismiss a11 his wives except one as a prerequisite for baptism, it is advocating divorce and must, therefore, make the painful assessment of whether or not such a move can be justified on ethical and theological grounds. 
CHAPTER III

THE THEOLOGICAL AND BIBLICAL

CONSIDERATIONS

It has been established that within many African societies with their emphasis on group significance and procreation, polygamy is regarded as the normal pattern of marriage. This norm is not an expression of depraved sexuality. It is rather a result of economical, social, and ideational pressures operating within such society. A polygamist, in his traditional environment, is living within that norm. Chapter 1 emphasizes that in establishing whether or not a change of norm is necessary, one must use as criterion the external, absolute, and objective standard of Holy Scripture. The task of this chapter, then, is to evaluate the polygamous norm in light of biblical revelation with the purpose of ascertaining whether or not such a norm would be acceptable within a Christian community.

\section{Textual Refutation of Polygamy}

Various passages from Scripture are quoted as proof that the Scriptures condemn polygamy. The admonition against multiplying wives given in Deut $17: 16,17$ is used as an apologetic argument for monogamy. The same text, however, warns against acquiring an excessive number of horses, as well as much gold and silver. The 
context, therefore, indicates that it is rather a warning against abuse of the practice than against polygamy per se. In addition, it is specifically directed against foreign wives, for fear they would turn the kings to foreign gods (1 Kgs $11: 1-8$ ).

The fact that the polygamy of Abraham and Jacob is said to be introduced apologetically because of the barrenness of their wives is another argument used against polygamy (Gen 16:2-9). So aliso js the grief of Esau's parents upon his marriage to two foreign women, al though the context would indicate that their grief was caused by the fact that the women were foreign (Gen 26:35).

The polygamy of the kings in the Bible is cited as another argument. Monogamists argue that polygamy is shown to be a source of temptation and corruption, thus indicating God's condemnation of this situation. But, if one is objective, one must say that it is not possible to draw from these texts any direct condemnation of polygamy as an institution. It is rather the abuse of the institution and the tendency of the foreign wives to adversely influence kings which is emphasized.

'Jesus' reference to divorce (Mark 10:2-12; Matt 19:3-9; Luke $16: 18$; Matt $5: 31,32$ ) is said to indicate a condemnation of polygamy. If He was strict on divorce, so the reasoning goes, it is not conceivable that He could tolerate polygamy. The problem with using such arguments, as Hillman ${ }^{2}$ has pointed out, is that the case against polygamy is developed only

${ }^{1}$ See White, Patriarchs and Prophets, p. 179.

${ }^{2}$ For discussion see Eugene Hillman, Polygamy Reconsidered (New York: Orbis Books, 1975), p. 141. 
by inferences and rests on assumptions which are not self-evident. There is a very real danger of reading into the Bible what one expects to find there, especially when these expectations may be shaped by one's own cultural traditions.

Other references, 1 Tim $3: 2$ and Titus $1: 6$, have also been used as textual argument against polygamy. Robert Holst cites four possible interpretations of these texts:

1. Church leaders could not be polygamous.

2. Church leaders could not take a second wife (after death or divorce from the first wife).

3. Church leaders must be faithful in their monogamous marriages.

4. Church leaders could not be single men.

The interpretation of neither text can be construed as a total condemnation of polygamy.

If interpretation number 1 is adopted, it immediately gives the impression that church leaders should be monogamous in contrast to what was at least a possibility. In fact, these texts are also used by those attempting to find a case for polygamy. The condemnation found in the Bible against the works of the flesh--fornication, uncleanness, and adultery (1 Cor 5:11; Gal 5:19-21; Heb 13:4)--are also used as arguments against polygamy. This is a serious charge because there is no biblical basis for equating polygamy and adultery. For "according to the biblical interpretation of this sin, adultery could be committed only between persons who were not validly and licitly married to each other. ${ }^{2}$

ISee Holst, p. 210.
2Hillman, p. 146. 
From the discussion in the preceding chapter, it has been found that the polygamous union is a real marriage and it must be concluded that there is no biblical support for classifying polygamy as adultery and fornication.

One must admit then that in scrutinizing individual texts objectively, one cannot find a single text which explicitly forbids polygamy or commands monogamy, unless there is read into these texts interpretations which are not self-evident or free from one's own socio-historical assumptions. Barth sums up the problem of finding textual refutation of polygamy thus:

We can hardly point with certainty to a single text in which polygamy is expressively forbidden and monogamy universaliy decreed. If, then, we approach the Bible legalistically, we cannot honestly conclude that in this matter we have to do with an unconditional law of God.1

Hastings further notes that "if Scripture is to be used simply in a rather formalistic and legalistic way concentrating upon the explicit meaning of individual texts, then it is indeed difficult to find any ground at all for the Church's persistent rejection of polygamy." 2

\section{The Scriptural Teaching on Marriage}

Instead of looking at individual texts to support or refute polygamy, one must look at polygamy within the wider scriptural teaching on marriage. The biblical ideal of marriage is the norm against which African as well as Western marriage institutions must be judged.

${ }^{1}$ Karl Barth, On Marriage (Philadelphia: Fortress Press, 1968), p. 22. (Emphas is supplied.)

${ }^{2}$ Hastings, p. 74 . 
Bowker explains that in the Bible there is extreme emphasis on relationships as a means of obtaining a deeper understanding of God and His redemptive plan for man. It is not surprising, therefore, to find that the intimate relationship between a man and a woman is used frequently as a shadow--an allegory--of God's relationship with man. E. G. White notes: "By marriage is represented the union of humanity with divinity. "1

\section{Marriage--A Covenant Relationship}

It is significant that in the Bible the word used for God's relationship with Israel, b'rith (covenant), is also used of the institution of marriage. The covenant relationship between Yahweh and His people is described by the image of marriage in such messages as Isa $50: 11 ; 54: 6,7$; Jer 2:2; Eze 16 .

Shillebeeckx comments that the intimate and loving relationship of God with His people was expressed in the prophetic proclamations and through the everyday symbol of human marriage.

The married life of human beings... . with the recollective pleasure of happiness enjoyed and the more bitter memories of hard times, infidelity, and the deprivation of love--all this formed the prism through which the prophets saw the saving covenant of God with his people, and enabled the people to comprehend the covenant. Human marriage became the means of revealing the covenant of salvation.?

Marriage Imagery Used to I1lustrate Biblical Doctrines

The marriage image illustrates many biblical doctrines. It brings into focus the doctrine of God. God is the husband who

1Ellen G. White, Christ's Object Lessons (Washington, D.C.: Review and Herald Pub. Assoc., 1947), p. 307.

${ }^{2}$ Shillebeeckx, p. 31 . 
provides for his people, who is grieved by disobedience and unfaithfulness. God reveals in the symbol of marriage His love, clemency, and longsuffering.

The marriage institution also has implications for the doctrine of sin, which from this point of view is characterized as adultery (Hos $2: 2$; Jer $3: 9 ; 13: 27$ ). Hosea in the description of his own marriage used it to illustrate God's patience with sinful man.

We see his wife as a harlot and as adultress who deserts him and lets him down. Instead of punishing her with the severity of the law, he brought her back to him and resumed their marital life; an illustration of Yahweh's infinite patience and forgiveness for faithless Israel. 1

In this context, the essence of sin consists of indifference or even hatred of God and the giving of one's affection to other objects (Hos 2:5; Jer 2:20; Ezek 20:30). It is unfaithfulness to solemn obligations and ingratitude for His favors (Jer 5:7). Turning away from God is, in the Scriptures, often compared to adultery (Jer 3-6; Ezek 23:37). In this connection E. G. White notes:

The unfaithfulness of the church to Christ in permitting her confidence and affection to be turned from Him, and allowing the love of worldly things to occupy the soul, is likened to the violation of the marriage vow. The sin of Israel in departing from the Lord is presented under this figure; and the wonderful love of God which they thus despised is touchingly portrayed: "I sware unto thee, and entered into covenant with thee, saith the Lord God, and thou becamest Mine." . . . "As a wife treacherously departeth from her husband, so have ye dealt treacherously with me, 0 house of Israel, saith the Lord"; "as a wife that committeth adultery, which taketh strangers instead of her husband!" Ezekiel 16:8, 32; Jeremiah 3:20.2

The allegory of the marriage relationship also teaches that

1J. Dominian, Christian Marriage (London: Darton-LongmanTodd, 1964), p. 21.

${ }^{2}$ White, Great Controversy, pp. 381,382 . 
continuance in sin will be punished--" That persistence in it entails a casting off of which human divorce is a pale emblem" (Hos 2:12; Jer $2: 15)^{1}$

Furthermore, the marriage institution illustrates the doctrine of Christ, Christ's love for and leadership over His church and His intimate union with her through the indwelling Spirit. In 2 cor 11:2 and Eph 5:23-32, Paul sees human marriage in the context of Christ's bridal relationship with the church. A better translation of Paul's declaration in Eph 5:32 "this is a great mystery" would be "this mystery is great." Here, mystery does not mean enigma, it means rather a spiritual truth revealed in a veiled manner. This truth is Christ's bridal relationship with His church and it is based on the marriage union described in Gen 2:24. According to Paul's view, the "great mystery" which is revealed in a veiled manner in Gen 2:24 is the "one flesh" relationship between Christ and His bride--the church.

Shillebeeckx argues that the covenant relationship between Christ and his Church is represented in the marriage relationship. "Christ, the one who loves, redeems and cares for the ciurch, is presented as a model for the husband in his married relationship with his wife." 2

The marriage union also illustrates the doctrine of eschatology. Christ's second coming is as sudden as the coming of the bridegroom (Matt 25:1-13). It describes the bliss, security, and glory of the everlasting kingdom using the human terms of a marriage feast (Rev 19:6-9).

IW. P. Patterson, "Marriage," in James Hastings, Dictionary of the Bible, $3: 279$.

${ }^{2}$ Shillebeeckx, p. 116. 
To the mind of Jesus the gladness of the wedding festivities pointed forward to the rejoicing of that day when He shall bring home His bride to the Father's house, and the redeemed with the Redeemer shall sit down to the marriage supper of the Lamb. He says: "As the bridegroom rejoiceth over the bride, so shall thy God rejoiceth over thee." ?

The marriage union is further used in the Bible to describe the doctrine of righteousness by faith. The imputed and imparted righteousness of Christ is symbolized by the wedding garment and as bridal adornment (Rev 19:8).

Christ's righteousness alone can avail for his salvation, and this is the gift of God. This the wedding garment in which you may appear as a welcome guest at the marriage supper of the 7amb. ${ }^{2}$

The Marriage Image as Re-

\section{ciprocal Illumination}

Marriage then, and the man/woman relationship within it, is of such importance that the relationship is analogous to the reTationship between Yahweh and His people--Christ and His church.

But the biblical use of the marriage image also gives an insight into the nature of the marriage itself. It is then a reciprocal illumination as Schillebeeckx describes it: "Revealing his covenant through the medium of human marriage, God simultaneously revealed to men a meaning of marriage which they had not hitherto suspected. ${ }^{13}$

Therefore, if the marriage analogy can unlock the mystery

TEllen G. White, The Desire of Ages (Mountain View, CA: Pacific Press Pub. Assoc., 1940), p. 157.

${ }^{2}$ Ellen G. White, Selected Messages, book 1 (Washington, D.C.: Review and Herald Pub. Assoc., 1958), p. 331.

${ }^{3}$ Schillebeeckx, p. 33. 
of the body of Christ, the opposite is also true. Christian marriage then, must model itself upon the picture of Christ and His church. True, the marriage institution is part of the whole creation which is under the bondage of $\sin$. Yet through the redemptive power of Christ, His followers regardless of the culture to which they belong, must pattern their marriage upon the ideal which God established at the dawn of creation. This is a sanctifying process to which all Christian marriages, regardless of culture, must be committed.

\section{The Biblical Norm of Marriage}

Consequently, if one desires to know the biblical norm of marriage, we must go back to the source, to the divine institution of marriage expressed in Genesis. For "It was God himself, who in this first marriage gave the woman to the man. . . Marriage was thus a good and holy undertaking, bearing God's blessing in the structure that God intended it to have."1

Ephesians 5:31 clearly shows the authority of the creation story as found in Gen $2: 23,24$, so also Christ's pronouncement on marriage in Matt 19:5, 6 and Mark 10:7. Here, the appeal to the creation narrative relates the discussion of any deviation (divorce) to God's original purpose for marriage. Lane points out that "the citation of Gen $1: 27$ and $2: 24$ does not reflect an arbitrary decision as to God's will, but entails an appeal over against legislation based upon fallen history to the true nature of human

I Ibid., pp. 16, 17. 
existence as it was revealed from the beginning of creation." 1 so Christ is referring to the original prototype of marriage presented in the creation narrative and the ultimate restitution of the institution to the perfection which it has lost because of $\sin$.

In His pronouncement, Christ pointed back to marriage before sin entered the world and showed that the God-intended ideal of marriage is reciprocity, unity, and permanency. This, then, is the objective norm for all cultures and the ideal toward which all Christian marriages, regardless of cultural background, must strive.

Reciprocity. Reciprocity includes equality. Both men and women were given equal worth and dignity in creation. Neither sex is superior or inferior to the other. Genesis 2:23 states: "This at last is bone of my bones and flesh of my flesh; she shall be called woman because she was taken out of Man." In this description, one sees the woman as of intrinsically the same nature as Adam. This is acknowledged by him as he declares her to be bone of his bones, flesh of his flesh. "In giving her the name woman, which in Hebrew is ish'sha, there is a play on the word ish, which stands for man and points further to the unity and equality of our first parents. "2 The subjection of the woman under man (Gen $3: 16$ ) is not a divine desire or commandment, but the destructive result of sin. In Genesis God offered a means of knowing his original intention for the man/woman relationship. Schillebeeckx states that "A

William L. Lane, The Gospel According to Mark (Grand Rapids: Eerdmans', 1974), p. 355.

2 Dominian, p. 18. 
servile submission of the wife to the husband.. . was seen even in Genesis as a sinful situation." 1

The creation narrative, then, points to the original greatness and dignity of man and woman and the reciprocal structure of their relationship. "So God created man in his own image, in the image of God he created him; male and female he created them" (Gen 1:27). The last sentence is repeated in Gen 5:2. Here, Bowker mentions that in some of the versions of Genesis current at Jesus' time, this expression was even more emphatic and was one of the very few variants which the rabbis accepted from the Greek Bible as corresponding to the Hebrew text. "Male and female created he him." This sentence, according to Bowker, has prompted extravagant theories concerning Adam's original form and appearance but, "in essence the change in number from plural to singular emphasizes the total creative harmony of relationship in the original intention of God. This is the natural state of man, the state which marriages endeavour to recover. ${ }^{2}$

Christ's attitude toward women was one of respect and equal recognition.

It is impossible to distinguish women from men in the personal respect with which Jesus treated them. . . I It is no accident that in the movement which he originated it came to be understood that the distinction of sex represented no difference of spiritual status; there was no male and female (Gal. $3: 28) .^{3}$

\section{${ }^{1}$ Schillebeeckx, p. 19.}

${ }^{2} \mathrm{~J}$. W. Bowker, "The Correlation of Theological and Empirical Meaning," in Marriage, Divorce and the Church (London: S.P.C.K., 1972), p. 102 .

${ }^{3}$ Harry Emerson Fosdick, A Guide to Understanding the Bible (New York: Harper \& Brothers, 1938), p. 130. 
The Apostle Paul, although accused of being an antifeminist, must be understood against the situation of his days and must be applauded for ideas ahead of his time. He faced the perplexing practical situation. His forbidding women to speak in church must be understood with the local situation in mind (1 Cor 14:34-35). 1

The idea of man's and woman's basic equality and unity is a great challenge to the fertility oriented concept of marriage predominant in traditional African thought, where the woman does not exist primarily for her own sake or in her own right. Her main purpose and duty in life is to bear children. Regarding this concept, Berglund explains that the idea behind the biological issues of marriage is that the male is the carrier of 1 ife, hence all important. Being the carrier of life, the man has the elevated role both in family and society. Therefore, also, he bears the shame and sense of guilt, vis-a-vis the family and the local community, if he is incompetent in transmitting life. "Whilst the male has dominion and role, being the head, there is marked discrimination against the woman and the role she plays. "2

Polygamy is a natural outgrowth of the fertility oriented concept of life. A husband is not tied to a single woman or wife, and his attention is geared to the children that his wives can and may bring to him and his lineage. "Polygamy is not only accepted in communities where the fertility-oriented concept is practiced,

\section{${ }^{1}$ For discussion see Fosdick, p. 131.}

${ }^{2}$ Axel-Ivar Berglund, "The Biblical Concept of Man/Woman Relationship," quoted by T. D. Verryn, ed., in Church and Marriage in Modern Africa (Johannesburg: Zenith Printers, 1975), p. 3. 
it is encouraged and honored. . . Fertility is the measuring rod whereby the worth of, and dignity in life are evaluated. "I

The fertility oriented concept of human love is a deviation of God's original purpose. It is the result of man's fallen state with its problem of death, survival and the preservation of the family.

The presence of death restricts man. Marriage will thus become a means of compensating for the disability, of surviving in one's children. It is for this reason that procreation is now [after the fall] the primary object of marriage, and the barren wife despairs as though she has not fulfilled her duty (Gen $30: 1 ; 29: 32$ ). Marriage has thus become a means of ensuring a future, a remedy in the face of death. 2

In Israel, childlessness was especially lamentable, because it interfered with the nation's messianic hope (Isa 49:20-23). Pretorius comments that the childless Israelite was barred from participation in the continuation of God's nation. The birth of a child was a happening of theological value. In Israel, therefore, procreation was theocentric.

Childlessness is also a personal tragedy in African society. But procreation must here be characterized as anthropocentric. The child maintains the continual chain of generations, linking the ancestral soul to its descendants. The individual is, therefore, an indispensable link in this chain. In this manner man has eternalized himself.

The Christian message with its emphasis on the second coming of Christ, bringing eternity to life, removes the sting of

${ }^{1}$ Ibid., pp. 5, 8 .

2J. J. Von Allmen, Vocabulary of the Bible (London: Lutterworth Press, 1959), p. 254. 
childlessness. Because of faith in the resurrection, procreation is no longer the primary end of marriage and the means of ensuring survival after death. A new possibility of eternal life has been offered (John $17: 3$ ).

The motive that "our names should not be blotted out" becomes obsolete. In contrast to the old Testament, the New Testament never directly connects the sexual act with procreation (1 Cor 7:1-9). That what constitutes the womanhood of a female is no longer the capacity to have children, but rather to have a husband (cf. 1 cor $8 f$. ). In marriage the production of children is overshadowed by the marriage itself.'

Here, then, the original plan of God for the man/woman relationship is recalled. Children are a blessing to marriage, but are an additional blessing.

When God created Adam and Eve, He blessed them and then He said to them "Be fruitful and multiply" (Genes is 1:28). From the Hebrew text it is clear that this commandment was an additional action of blessing. . . . The child does not make marriage. . A A childless marriage is also a marriage in the ful1 sense of the word. 2

It is difficult to visualize full reciprocity in a polygamous marriage. The fertility-oriented concept, which is the essential basis for polygamy, is in its very essence discriminatory towards women.

True, the Westerner has often exaggerated the women's inferior role in a polygamous society. Yet, women have their rights within a polygamous marriage. The husband is expected to be fair in economical and sexual matters, and the society has spelled out the structural relationship between the parties concerned.

$1_{H .}$ Pretorius, "Childlessness," in T. D. Verryn, ed., Church and Marriage in Modern Africa (Johannesburg: Zenith Printers, 1975), p. 121.

2 Walter Trobish, I Married You (New York: Harper and Row Publishers, 1975), p. 21. 
But the polygamous structure is basically a non-reciprocal one, while the monogamous one is basically reciprocal. This does not mean that all monogamous marriages live up to the ideal of reciprocity.

Monogamous marriage does not in any way guarantee real reciprocity, and in fact traditional attitudes toward monogamous marriage in the West were often far from encouraging a genuine reciprocity. Nevertheless, the monogamous structure remains an essential reciprocal structure, while the polygamous structure is not. It is essentially unequal, in principle limiting the right of the women in a way that must seriously affect their whole psychological relationship to each other. It is one thing to tolerate non-reciprocity in the practice of marriage, it is another--and much more serious--to accept it into the very structure of marriage. 1 (Emphas is supplied.)

One cannot, however, simply equate monogamous marriage of whatever quality with God's revealed will.

Indeed, the biblical concept of marriage and its basic equality of man and woman before God presents a challenge to all cultures. The Western variation of the fertility concept with its exaggerated preoccupation with sexuality and marked tendency of reducing the woman to a sex symbol represents a situation clearly in need of the sanctifying power of the Holy Spirit. E. G. White comments: "The marriage relationship is holy, but in this degenerated age it covers vileness of every description. It is abused, and has become a crime which now constitutes one of the sins of the last days." 2

Unity. God's intended purpose of the marriage institution also includes unity (Gen 2:24: "Therefore shall a man leave his

1 Hastings, p. 75.

2 Ellen G. White, Testimonies to the Church, 9 vols.

(Mountain View, CA: Pacific Press Pub. Assoc., 1948), 2:252. 
father and mother, and shall cleave unto his wife; and they shall be one flesh"). The literal sense of cleave is to stick, to paste, to be glued to a person. The marriage tie is firm, surpassing even the natural blood ties existing between parent and child.

In the condition of the ideal marriage, the woman is not incorporated into the clan or family of the husband. Rather both leave their parents, both form a new unit, both operate a new home, both go out from their environment to meet at a third meeting place. The message that the woman is not incorporated into her husband's family or clan is a clear witness against the fertility and procreational thought pattern characteristic of fallen man.l

But leaving does not mean abandoning one's responsibility towards parents and family. It simply means that the claims of the family or clan must not overshadow the claims of the marriage partners towards each other. Nothing must disturb this new unity formed by marriage. Berglund declares that the use of the singular in the Genes is text underlines the urgency of the word 'cleave'. The language is a clear symbol of unity. "A total committal to one another without interference caused by a second belonging elsewhere. Originally the man and the woman were one flesh. Therefore they must come together again, and thus, by divine will, they belong together. ${ }^{2}$ Here again, equality as well as unity is stressed. The woman is not an instrument for a definite purpose (pleasure or childbearing) but the other half of creation valued for her own sake.

This oneness is both spiritual and physical. The Hebrew word 'flesh' is basar. It implies living physical flesh, including the ability to participate in the procreative act. Therefore,
${ }^{1}$ Berglund, p. 18.
2 Ibid., p. 19. 
according to Gen 2:24 sex "belongs to the man/woman relationships of marriage to that extent and depth that the two, in reality and essence, become one flesh. Herein lies the mystery of human togetherness in marriage, a mystery applicable also to the unity between Christ and His church (according to Ephesians). "l By insisting on the fact that marriage was instituted before the appearance of sin, Scripture contradicts every teaching which would see in the sexuality of man the disreputable or shameful part of his being. True, the sex union between man and woman, when lawless, has been perhaps the most demonic, disruptive force in the social history of mankind. Many of the fiercest human passions and the darkest crimes come from sex; but loyalty, love, and the deepest and most enduring human relationships are also rooted here. It is "this biological 'covenant' which the biblical revelation employs as its boldest symbol for the covenant between God and his people." ${ }^{2}$

There is, therefore, no opposition between God and fertility. God said: 'Be fruitful and multiply'. It is the corrupt misuse of God's intention with fertility which is wrong. When it becomes lustful or an instrument of salvation or survival, it is a deviation of God's intention of this gift. Becoming one flesh means more than the physical aspect of marriage. It implies total commitment and belonging. The conjugal union is shown to be a spiritual oneness, a vital communion of heart as well as that of the body. The

\footnotetext{
${ }^{1}$ Ibid., p. 21.

2Theodore 0. Wede1, "The Epistle to the Ephesians," in IB $10: 727$
} 
marriage union has its foundation in love, as it reflects Christ's Tove for the church (Eph 5:25). This love strengthens the physical relationship and is itself strengthened by this relationship.

Love does not only receive strength from the physical fellowship, it also gives the one-flesh union strength. Love longs for the physical expression, deepens it and makes it meaningful and precious. As an act of married love, the one flesh union becomes an 'act of love' in the full sense of the word.1

But the biblical idea of love does not imply the sentimentalism and possessiveness often so predominant in Western man/ woman relationships. White notes here that "Imagination, lovesick sentimentalism, should be guarded against as would be the leprosy. "2 Rather, love is a principle--a precious gift from God; "pure and holy affection is not a feeling but a principle. ${ }^{3}$ It involves the emotions, but it is also an ethical attitude and is, therefore, capable of deliberate exercise and direction. The structure of commitment between husband and wife deepens as the marriage matures.

There is a parallel between marital and religious commitment, so that they mutually illuminate one another. A marriage based only on emotion is as precarious as a religion based only on feeling. A marriage of mere convenience is as defective as a religion which consists only of conventional obligations. 4

Barth calls this structure of commitment full-life-partnership and sees it to exclude polygamy:

- . There can be no third person alongside them. How can that mutual iiberation and freedom in fellowship which is so constitutive of marriage be genuinely attained, if at the same

${ }^{1}$ Trobish, pp. 36, 37.

${ }^{2}$ Ellen G. White, Adventist Home (Nashville, TN: Southern Pub. Assoc., 1952), p. 51 .

${ }^{3}$ Ibid., p. 50.

4 Marriage, Divorce and the Church, p. 33. 
time it is also demanded of a second partner and can be to the advantage of this or that third party? And how can there be fellowship in this freedom if the orientation to each other in which alone it can be realized has to be constantly divided between two very different second partners? And how can the order of life-partnership be fulfilled if there are two firsts and two seconds? In every dimension, a third party, whether male or female, can only eo ipso disturb and destroy full-lifepartnership. If marriage as such, under and in virtue of the divine command, is full life-partnership, it is necessarily monogamous. ${ }^{1}$

Dwane makes the following comments: "It is in this inability to satisfy the need between two partners to belong to each other, and give themselves to each other without holding back, that a polygamous marriage must come down. ${ }^{2}$

Permanency. God's original plan for marriage also includes permanency. Marriage as a type of Yahweh's covenant with his people--Christ's relationship to His church--should have the same permanency (Eph 5:32).

In the Bible the sacred and enduring character of the relation that exists between Christ and His Church is represented by the union of marriage. The Lord has joined His people to Himself by a solemn covenant, He promising to be their God, and they pledging themselves to be $\mathrm{His}$ and $\mathrm{His}$ alone. He declares: "I will betroth thee unto Me forever; ye, I will betroth thee unto Me in righteousness, and in judgment, and in loving-kindness, and in mercies. 3

In the same line of thought, Barth comments that in love and marriage is mirrored the faithfulness of God to His covenant partner and the enduring ties between them. In marriage is reflected the fidelity of Christ towards His church. Comprehensively, marriage symbolizes the fidelity with which God the Creator coexists with

1Barth, p. 19.

2S. Dwane, "Polygamy," in Verryn, p. 235.

3 White, Great Controversy, p. 381. 
the whole world, and thus it is the permanency which is assured to

His creation. Marriage, then, is a lasting "life-partnership."

The permanence of marriage is the content of the divine command. Where this divine fidelity and the resultant stability of its creaturely partner is manifest and recognized, we can appreciate the majestic decision in regard to marriage recorded in Mark 10:9 and Matt 19:6. "What therefore God has joined together, let no man put asunder."]

Divorce signifies a distintegration of the natural state of man as seen in Christ's statement in Matt 19:8: "but from the beginning it was not so." Here Jesus points out that the command of Moses was only a permission and nothing more. Something has intervened since God enunciated the law of marriage in the Garden of Eden. The destructive forces of sin brought havoc also in the marriage institution. Moses' regulations were nothing more than a concession to this evil condition, and never went beyond it. It constituted nothing but a legal form of dissolving marriage. But Moses' regulation did not alter God's original intention of permanency in marriage as written in Gen $1: 27$ and $2: 24$.

Legal separation is not sufficient to make void the marriage covenant in the eyes of God.

A woman may be legally divorced from her husband by the laws of the land and yet not divorced in the sight of God and according to higher law. There is only one sin, which is adultery, which can place the husband or wife in a position where they can be free from the marriage vow in the sight of God. Although the laws of the land may grant divorce, yet they are husband and wife still in the Bible light, according to the laws of God.2

God's joining together man and woman in the creation of Adam furnishes the constant sanction of marriage. God is the

'Barth, p. 30. ${ }^{2}$ White, Adventist Home, p. 344. 
author of this union, and the couple should not in violation of divine purpose separate.

Divorce is a pale emblem of the final "casting off," the absolute separation of unregenerated man from God's saving grace. It illustrates the severance of a covenant relationship. It is, therefore, a serious thing in the eyes of God, whose attitude towards divorce is expressed forceful1y in Mal 2:14-16: "Because the Lord hath been witness between thee and the wife of thy youth, against whom thou hast dealt treacherously. Yet it is she thy companion, and the wife of thy covenant. . . Therefore take heed to your spirit, and let none deal treacherously against the wife of his youth. . . For the Lord, the God of Israel, saith that he hateth putting away."

The biblical norm then in regard to marriage is reciprocity, unity, and permanency. Marriage as the ideal form of human fellowship illustrates the great transcendental truth of God's relationship to man. Therefore, marriage, as in Barth's words, is "an invitation, permission and freedom to represent and symbolize in this human form of fellowship, the fellowship of God with man, in the choice of love, his free and gracious election, and in the bond of marriage the faithfulness of his covenant."

The ideal marriage situation for the realization of this Gospel command is monogamy. This does not mean that a 71 monogamous marriages are fulfilling this command. As part of the fallen creation, marriage is always less than perfect, yet always striving

'Barth, p. 20. 
to restore the lost image of God in man. Marriage, as a 11 human institutions, needs to be regenerated by the work of grace from within. As part of the creation which is awaiting to be delivered from the bondage of $\sin$ and corruption, marriage needs to be reconciled to God in Jesus Christ. "Any marriage potentially points toward the recovery of the natural or 'paradisal' state, the total bonding of man and woman, and of both with God. "1 This is, then, the process of sanctification. Through a lifetime, marriage progresses toward that perfect reflection of the love of God for mankind. E. G. White comments: that "to gain a proper understanding of the marriage relation is the work of a life time. Those who marry enter a school from which they are never in this life to be graduated. ${ }^{2}$

True to the biblical ideal; the church must uphold monogamy as the fullest expression of love and unity between man and woman, and, therefore, as the deepest reflection of God's relationship to mankind. Thus the church must "inevitably promote institutional monogamy rather than institutional polygamy. ${ }^{3}$

Christian marriages of whatever culture they belong will, in obedience and through the indwelling power of the Holy Spirit, pattern their relationship according to this holy ideal. It is, therefore, not "an open question for one to enter into a polygamous marriage. For a married person, marriage stands very close to the core of being Christian, and this means that--in so far as it now

1 Bowker, p. 102.

${ }^{2}$ White, Adventist Home, p. 105.

3 Barth, p. 28. 
depends on one--it must be made a witness, both by its structure and by its spirit to the Christian vision of man and of Christ." The partners in a Christian marriage will, therefore, commit themselves to the monogamous structure of marriage which God established at the dawn of creation.

Does the polygamous norm need to be changed? It seems that one must answer in the affirmative. Polygamy is a deviation of God's original plan for the marriage relationship. E. G. White notes that it had been introduced "contrary to the divine arrangement at the beginning." 2 "In the beginning, God gave to Adam one wife, thus showing his order. He never designed that man should have a plurality of wives. ${ }^{3}$

But, an essential distinction must be made between the polygamist coming out of paganism who seeks to enter the family of God and a member of that family who becomes a polygamist. "The former seeks to enter into an obedience to Christ which his circumstances do not permit him fully to perform. The latter standing in the area of obedience, and against better knowledge becomes disobedient. "4 This is sin--willful and knowing disobedience to God.

Recognizing the importance of upholding the monogamous norm with sharpness and intransigence, Barth nevertheless notes:

Situations can and do arise, therefore, in which it would be sheer brutality for the Christian church to confront men with

$1_{\text {Hastings, p. } 76 .}$

2 White, Patriarchs and Prophets, p. 91.

3 El len G. White, Spiritual Gifts, vol 3 (Washington, D.C.: Review and Herald Pub. Assoc., 1945), p. 99.

${ }^{4}$ Hughes, p. 207. 
choice between baptism and institutional polygamy. The decision of theological ethics in favor of monogamy as against polygamy calls for a clear recognition of matter and purpose, but not for brutality of form and method. 1

\section{The Dilemma--Polygamy or Divorce}

The man who comes to Christ while already committed to a polygamous marriage represents one of the most difficult problems facing the church in Africa. This situation clearly reminds one of the plight of fallen mankind and the tension between Gospel and culture. In requiring a man to choose between divorce and polygamy, the choice rests between two realities which are both deviations of God's intent for man. The dilemma is that the church wants monogamy and does not want divorce. Yet it cannot have one without the other. One may well say that there is no real solution to the dilemma, and that one may simply cling in faith to the saving grace of Christ and the promise of its power to save men of whatever circumstances they may find themselves in this life.

Faith is the only precondition for grace. The Holy Spirit received through faith cleanses the springs of action, and works repentance, righteousness, and obedience. "The call goes forth," says Bonhoeffer, "and it is at once followed by the response of obedience. "2 But what constitutes true obedience in the polygamist's situation? His obedience to the ideal of monogamy precipitates another disobedience, that of divorce. His problem is not that he does not want to be fully obedient. It is that he

Barth, p. 28.

2 Dietrich Bonhoeffer, The Cost of Discipleship (New York: Macmillan Co., 1963), p. 48. 
cannot be fully cbedient. In this dilemma, one must hold on to the promise that no problem is too 'tangled' for the love of God, and that the polygamist who finds himself faced with the choice between divorce and polygamy and sincerely desires to do God's will stands fully within God's mercy and grace. To assert the contrary would deny the basic doctrine of justification by faith and the all sufficiency of God's grace. Trobish notes: "There are situations in life where we have the choice between two sins, and where the next step can only be taken in counting on the forgiveness of our crucified Saviour." 7

Caught between the two biblical principles of monogamy and indissolubility, the repentant polygamist must throw himself on divine mercy alone. This is the new birth experience and by virtue of it, a new member has been added to God's family. Here Peter's rhetorical question still rings out: "can any one forbid water for baptizing these people who have received the Holy Spirit just as we have?" (Acts 10:47).

The Pauline Privilege

Theologically, two distinct possibilities are open to the converted polygamist, two possibilities which are equally "acceptable" or "unacceptable"--to retain his wives and bring them with him into church or to divorce them. But here another dimension enters the picture--the underlying principle of all Christian conduct: justice, mercy, peace, and love. In this connection, the text of the

1Walter Trobish, "Congregational Responsibility for the Christian," Practical Anthropology 13 (Sept.-Oct. 1966):211. 
apostle Paul in 1 Cor $7: 10-20$ is relevant to the polygamy situation because it shows the application of the ideal principles of marriage to a concrete, less-than-perfect, human situation. In this passage, the divine principle of "what therefore God has joined together let no man put asunder" (Mark 10:9) remains intact. It is from here Paul takes his departure when he states: "To the married I give charge, not I but the Lord, that the wife should not separate from her husband... and that the husband should not divorce his wife" (vs. 10). In verse 12, Paul addresses himself to the actual concrete problem as found in the Corinthian church--that of a newly converted Christian bound in marriage with an unbeliever. On this subject, the apostle does not claim to have a direct command from Christ ("But to the rest speak I, not the Lord"): he speaks with the inspiration and assurance of an apostle. While still holding forth the divine principle of indissolubility, "if any man has a wife who is an unbeliever and she consent to live with him, he should not divorce her" (vs. 12), he nevertheless admits the possibility of separation if the unbelieving partner so desires.

The principle underlying this concession is the Christian concern for peace, "God hath called us to peace" (vs. 15). The original command of God still remains in full force. Because of man's sinful condition, however, the strict and absolute adherence to this principle under all circumstances of life might create situations where other Christian principles would be violated. If Paul makes a concession to such situations, would not the same principle also apply in the case of a polygamous convert? In this 
case, the polygamist's strict adherence to the monogamous principle would violate another principle--the enduring character of marriage. Furthermore, a host of ethical problems present themselves if he is to follow the monogamous ideal to the letter. For "a non Christian has accepted life-long obligations by plural marriages from which he is not entitled to withdraw. To do so is frequently to cause real injustice and misery both to wives and children." 1 In the Bible as a whole, there is a balance between the stress on the individual and on social consciousness, whose guiding principle is justice, love, and mercy. This same balance must be sought in regard to the polygamy question. For polygamy is "the one reprobated act of which the sinner cannot effectually repent at his own cost alone. The relation once entered brings its own loyalties which demand respect. "2

Also, the New Testament sets ideals for many other relationships beside marriage--among others, the family relationship. "What must we say about an application of the scriptural ideal of monogamy which destroys the scriptural concern for the family? " 3

Would not the underlying principle in Paul's treatment of the concrete divorce problem in the Corinthian church also apply to the converted polygamist? Is there really any justification then for disrupting a society by demanding instant achievement of the monogamous ideal by a polygamous convert, without regard for the social and psychological consequences and the violation of other biblical principles this would entail? Is the principle of peace

$$
{ }^{1} \text { Hastings, p. } 77 . \quad 2 \text { Price, p. } 11 . \quad 3 \text { Boer, p. } 26 .
$$


maintained when forced dismissal causes conflict and confusion within the family and clan, necessitating in some instances legal intervention by customary or civil courts? Paut makes it clear that religion is not meant to cause upheaval in the established status of its new members. "So brethren in whatever state each was called, there let him remain with God" (1 Cor 7:24). Paul's admonition is to preserve order and faithfulness in life's relations and "to show that Christianity does not design to break up the relations of social and domestic intercourse." 1 The converts were to show the true nature of the Christian faith within the particular situation in which the Gospel had found them.

In the text under discussion, Paul insists that the break up of marital relationship should not be precipitated by the convert. "If any brother hath a wife that believeth not, and she be pleased to dwel1 with him, let him not put her away (vs. 12). If, however, the wife decides to depart, her husband is not to retain her. He is then no longer bound to her. "But if the unbelieving depart, let him depart. A brother or sister is not under bondage in such cases" (vs. 15). This reinforces the emphasis on the biblical ideal. So far as it remained within the power of the convert, this biblical principle was not to be violated.

The Pauline "privilege" would apply also to the polygamous convert. Separation, therefore, would be open to the polygamous convert under the circumstances laid down in the Corinthian text.

${ }^{1}$ Albert Barnes, Notes on the New Testament (Grand Rapids: Baker Book House, 1953), p. 127. 
Summary and Conclusion

In this chapter, it has been established that the polygamous norm, however acceptable within a given society, does not correspond to the biblical version of marriage as exemplifying God's inclusive covenant relationship with man. The illumination this relationship sheds on the qualities and characteristics of marriage as God ordained it is found to be incompatible with the principles underlying the polygamous norm.

An essential distinction has been made between the man embracing polygamy after conversion and the one who accepts the Gospel while bound in a polygamous relationship. The former is seen as willfully entering the area of disobedience. The latter, caught in a situation where full obedience is impossible, must throw himself on the mercy and all sufficiency of God's grace.

The text of Paul in 1 Cor $7: 10-24$ is seen as offering an insight into the application of the high biblical principles to a concrete, less-than-perfect, human situation. This text is also seen as shedding light on the problem of the polygamous convert in four ways.

1. The principle of this text indicates that God's original command remains in full force. Because of man's sinful plight, however, the adherence to this command under all circumstances of life may create situations where other Christian principles would be violated. Paul makes concessions in such circumstances.

2. The new religion is not to cause upheaval in the established social order. Rather the Gospel regenerates the established order from within. 
3. If the unbelieving partner(s) decide(s) to leave, the convert should not resist separation or divorce. Under such a circumstance, the convert is no longer bound to his or her partner(s).

4. The Christian principle of peace is to be maintained in a17 the convert's dealings with his or her partner(s). 


\section{CHAPTER IV}

\section{A HISTORICAL SURVEY OF THE CHRISTIAN CHURCH'S DEALINGS WITH POLYGAMY}

This chapter attempts to document the dealings of the Christian church with the polygamy issue through the years. Furthermore, it endeavors to point out some underlying factors contributing to the position of the church on the subject.

\section{General Historical Development}

The Monogamous Environment of the Early Church

Monogamy was, on the whole, the basic norm in the societies within which early Christianity gained a foothold. The Jews still allowed polygamy, but no doubt this institution had become increasingly rare. Roman and Greek societies were monogamous according to law, and in the nations within which Christianity was established, large scale polygamy was rare. Westermarck has pointed out that among the ancient West Germans only a few persons of noble birth had a plurality of wives. There is no direct evidence of polygamy among the Anglo-Saxons. The general custom among the ancient Irish was to have one wife, and the laws of ancient Wales did not permit polygamy. The idea that polygamy occured in ancient Gaul was probably due to misinterpretation. Furthermore, Westermarck explains that, more significantiy, the form of marriage among the 
Greeks and Romans was strictly monogamous, but divorce was easily obtainable. "Considering that monogamy prevailed as the only legitimate form of marriage in Greece and Rome, it cannot be said that Christianity introduced obligatory monogamy into the Western world." 1

Monogamy, then, has been the preference of Western society quite apart from religious considerations.

Socio-Historical Backgrounds of the Attitude of the Christian Church toward Polygamy

The relation of the Christian Church to polygamy was to a great extent determined by socio-historical development. In the early centuries of Christian thinking, the idea of marriage was exposed to certain constricting traits which do not exist today, but which nevertheless have left certain indelible marks on the outlook of Christians. Gnosticism, which competed with Christiánity for the conversion of the Mediterranean world, considered marriage evil. Greek thought, with its platonic idea, saw the soul imprisoned in the body. Detachment from passion became an important goal. Christianity did not entirely escape these influences and incorporated into its early philosophy and teachings a marked preference for the single state and a horror of sensuality--an attitude which has prevailed through the centuries.

As noted in chapter 2, polygamy is a natural outgrowth of the fertility oriented concept of marriage which stresses procreation. However, the concept of marriage in Western society has

\footnotetext{
Thestermarck, p. 50.
} 
emphasized sexuality. Therefore, the real causes of polygamy were often poorly understood by Western man. Because of his own cultural background the Occidental tended to regard polygamous forms of marriage in Africa as merely sexual arrangements. Thus, "the early missionaries assumed that the African was simply depraved when he married more than one wife. "I Polygamy, then, became associated with adultery, fornication, and exotic depravity. Briffault comments that "there is scarcely a feature of nonEuropean society which excites the same denunciation . . (as polygamy). Every other departure from European sexual codes, every vice even, is looked upon with leniency in comparison. "2 With their background of harsh European laws and sanctions against bigamy--a legal offense and degradation--the missionaries' strong reaction against polygamy is understandable.

Being made. aware of the socio-cultural background of those who shaped the attitudes of the Christian church toward polygamy, one can understand why the missionaries tended to consider polygamy a much greater evil than divorce. The preference for this choice was so strong that it was almost unanimously adopted in spite of the ethical ambiguity and social consequences.

The Dealings of the Christian Church with Polygamy

During the Middle Ages, polygamy was mainly the subject of theoretical and theological discussions. The Roman Catholic church

'Hughes, p. 205.

2 Robert Briffault quoted in John Cairncross, After Polygamy Was Made Sin (London: Routledge and Kegan Paul, 1974) p. 1. 
had to deal with the problem on a practical level in its missions in Asia and America during the late sixteenth century. Hastings notes that the Roman Catholic missionary practice in regard to marriage was stabilized at that time and has changed little since then. It refused baptism to a polygamist and also denied baptism to any wives in a plural marriage.

Most of the missionaries to Africa in the mid-nineteenth century were Protestants. Although their main attention was not fixed on the institution of marriage, the perplexities and problems encountered in regard to it confronted them continuality. Unfortunately, they were poorly prepared to tackle such an issue.

They had very little theology of marriage, if any to work from, and little historical sense of the relativity of social patterns. Christian marriage was as they had known it at home, as they endeavoured to practice it in their own little compounds, and the contrast between this and the confusing reality they witnessed in the world beyond was extreme indeed. Nor did they have much help from anthropologists to explain the latter to them, for a scientific study of marriage only developed well into the twentieth century. 1

On the whole, the early Protestant missionaries had very definite ideas about the outward manifestations of the conversion experience. Many customs they encountered in Africa were judged incompatible with the Christian teachings. Among these customs were polygamy and lobola (bride price).

Most Protestant missionaries were from the first, and long remained, strongly against both these things: polygamous unions were on the same level as adultery and must be firmly broken; lobola was the buying of a woman as a piece of property and quite unacceptable to Christians. Full church discipline was to be exercised against both.2

'Adrian Hastings, "The Church's Response to African Marriage," African Ecclesiastical Review 13/3 (1971):196.

$$
{ }^{2} \text { Ibid., p. } 194 .
$$


Little by little, as the missionaries gained further insight into the culture and customs of the people among which they worked, several began to doubt their earliest interpretations of these customs.

In 1863, the Anglican Bishop of Natal, John Colenso, challenged the refusal of the church to admit polygamists into church fellowship without dismissal of their wives. Colenso wrote: "I must confess, that I feel very strongly on the point, that the usual practice of enforcing the separation of wives from their husbands upon their conversions to Christianity is quite unwarrantable, and opposed to the plain teaching of our Lord."

Unfortunately, Bishop Colenso also held controversial views on other subjects and was cited for heresy for his doubts about the historicity of the Pentateuch. He was eventually dismissed from the service of the Church of England. Under these circumstances, it is understandable that his views regarding polygamy, although they were shared by many of his contemporaries, carried little weight.

In the Anglican Church in South Africa, the views of Bishop Colenso's opponent, Bishop Callaway, prevailed. His church became, for a time, one of the strongholds against leniency in dealing with polygamous converts. The issue eventually was brought before the Lambeth Conference of 1888. Inasmuch as four of the five bishops on the committee appointed to deal with this matter were from South Africa, the outcome was predictable. The conference denied

1J. W. Colenso, Three Weeks in Natal: A Journal of a First Tour of Visitation among the Colonists and Zulu Kaffers of Natal (Cambridge: Macmillan and Co., 1865), p. 139. 
baptism to any man living in polygamy, even though the union had been contracted before conversion.

Although the baptism of polygamists in Asia was common, the decision of the Lambeth Conference carried great weight in Africa, not only among Anglicans but among other Protestant missions as well.

The Lambeth Conference considered the case of the wives of a polygamist more leniently and was prepared, in some instances, to baptize them. However, the practice of various missions on this point was not uniform; it varied in different missions and sometimes even within the same mission.

The treatment of the polygamous families was discussed at the World Mission Conference of 1910. The record reads:

While there was an attitude of some tolerance expressed for polygamy from parts of Asia, particularly China and India, there was next to none for polygamy in Africa. In that continent, missionaries characterized it as an almost unmitigated evil. 1

The Lambeth Conference of 1920 reaffirmed the resolution taken in 1888. At the Le Zoute Conference on mission in Africa held in 1923, the problem of polygamy was again discussed with a more positive attitude toward local culture. Nevertheless, the majority still rejected the idea of baptizing polygamists. In 1930, a Synod of the Anglican Church in Uganda declared that a native marriage is a true marriage that is not to be repudiated nor repeated. But it also declared polygamy an evil that was not to be tolerated in the Christian church.

\footnotetext{
$1_{\text {Hastings, p. } 15 .}$
} 
While the polygamy issue originally was most acute in South Africa, the problem in East and West Africa increasingly demanded attention as churches grew in numbers and size. Some of these young churches broke away from the parent church and became independent, primarily over the question of polygamy.

During the first half of the twentieth century, a great diversity of opinions and practices in regard to polygamy were held by the various missions. Adding to the confusion was the fact that some missions moved from greater strictness to greater leniency while others did exactly the opposite. Thus it may be noted that arguments both for and against admitting polygamous members have been discussed for almost a hundred years and still the Christian church has no unanimous policy on the matter.

Tippet notes six different attitudes taken by various missions toward poiygamy:

1. Baptize the women and children but not the men.

2. Baptize none of them if they have anything to do with polygamy.

3. Baptize all on testimony of faith--polygamists or not.

4. Let the husband retain the first wife and divorce the rest.

5. Let him divorce all but the preferred wife.

6. For the first generation, baptize on a profession of faith, but demand monogamy thereafter. 1

For many years, the Evangelical Lutheran Church of Liberia, as well as other churches, accepted into their membership wives of polygamists. In 1948, the Lutheran church decided that such a stand

ITippet, p. 78. 
was $i l l o g i c a l$ and, thereafter, neither baptized nor confirmed any man or woman who was connected with polygamy. However, in 1951 the church reversed its stand of 1948. ATthough the church upheld monogamy as God's plan for marriage, it decided that

where evidence of true faith is shown and upon approval of the District Church Council, parties to an established polygamous marriage may be baptized and confirmed. However, it further confirmed that in accordance with St. Paul's teaching, no such person, man or woman, shall be permitted to hold office in the Church or congregation or be engaged as a Christian worker.

Development toward greater leniency is noticeable within other mission societies as well. From the outset, the Basel Mission in Ghana unreservediy condemned African polygamous marriage as unChristian and pagan.

A polygamous African who wanted to become a Christian had to divorce all his other wives except one. The negative and painful results on the divorced wives and their children are too clear to be imagined. This hurdle barred many men with more than one wife from being baptized into the church. 2

In synod after synod lone voices questioned the wisdom of this policy, but it was neither polite nor decorous to publicly voice any doubt about the matter.

It was not until the 1972 Synod at Tamale that the question was openly debated without embarrassment and a committee headed by Rev. A. K. Sah who was trained in theology in Hamburg reported that polygamy was accepted as a normal marriage form among the Jews of the 01d Testament. The prevalent idea of monogamy of the New Testament must have taken centuries to emerge. As a corollary it was not right or charitable to expect first generation Christians in the Northern and Upper Regions of Ghana, now turning to Christ for the first time, to be judged, delayed or driven from the Lord's message and love by the barrier of insistence on monogamy. 3

$1_{\text {Hastings, p. } 22 .}$

${ }^{2}$ Fred Agyemang, we the Presbyterians (Accra: Select Publications and Promotions, 1978), p. 39.

3 Ibid. 
The Synod, therefore, decided that first generation converts in Ghana should be accepted for instruction and baptism with all their wives and children.

At present the Salvation Army in Ghana has the following policy in regard to polygamous converts:

A man having more than a wife, who gives evidence of being soundly converted may be received as a soldier; he must, however promise not to take any more wives. His wives should be encouraged to attend the meetings and if converted may be received as soldiers. A man with only one wife, on becoming Soldier must promise not to take any more wives. Unmarried men Salvationists must promise if and when they marry to take one wife only. Any soldier breaking these rules must be suspended from soldiership. Under no circumstances may polygamists become Local Officers. 1

Among other churches now accepting polygamists for baptism are the following: the Mennonites, the Ghana Baptist Church, the Assemblies of God, the World-Wide Evangelization Crusade, and the African Methodist Episcopal Zion Church. ${ }^{2}$ The Anglican Church in Ghana permits baptism of a polygamist but it does not admit him to the eucharist or allow him to hold office in the church. ${ }^{3}$ The position of the SDA church in this matter, then, seems, at the present, to coincide with that of the minority of churches and missions operating in Ghana.

The General Memorandum of Guidance for Officers of Salvation Army (London: International Headquarters, 1946), p. 19.

${ }^{2}$ See R. H. Hall, "Marriage Law in Ghanian Churches," in Hastings, Christian Marriage in Africa, p. 22.

${ }^{3}$ This information was obtained through personal contact with an Anglican Priest in Accra, Ghana. 
The Seventh-day Adventist Church and Its

Policies on Polyganiy

The "Missionary Round Table" of 1913

There was no general united practice for handling the polygamy issue in the various missionfields of the SDA Church prior to 1913. In June 1913, the missionaries ${ }^{1}$ present at the General Conference at Takoma Park, Maryland, met with some of the administrators to discuss problems relevant to missionary work. The meetings were.called "The Missionary Round Table." Among other issues was an "informal discussion on dealing with converts from polygamous families." It centered on a recommendation drafted earlier by a "committee on the question of polygamy in heathen lands." ${ }^{2}$ The recommendation read:

WHEREAS, In heathen and Mohammedan lands polygamy is largely practiced,

We Recommend, That when a man practicing this custom becomes a Christian, he be accepted into the church on condition that he support all his wives and children, but that he lives only with the first wife as husband and wife. It be further understood that such a convert be not eligible to any office in the church.

In the case of a plural wife accepting Christianity, she be required, as a condition of church membership, to separate from her husband, and if possible to obtain his consent, or if the separation can be effected by legal process, that she be privileged to marry again. But if consent of her husband to separate be not obtained, she be received into church fellowship-with the understanding that she be not eligible to any office in the church. 3

ISee Appendix A for the names of some of the missionaries who were present during the meetings.

${ }^{2}$ This committee met earlier to draft a recommendation which was to be submitted to the Missionary Round Table. R. C. Porter was the chairman and L. R. Conradi, a member. The other members were not identified.

${ }^{3}$ See Clifton R. Maberly, "The Polygamous Marriage Variant: The 
The Round Table discussion revealed that the practice in most missions had been to refuse baptism to polygamists. Some of the missionaries, however, expressed doubt whether this was a just solution to the probiem. L. R. Conradi voiced his opinion thus:

When it comes to polygamy, that is a very difficult question. We have tried to steer around it the best we could, but it is pressing us very close. . . We read in Paul's instruction that the officers in the church should have but one wife. I think we will have to study that quite a while yet. It would seem to indicate that they were in the same stage of transition from the polygamous church in the days of the Apostles, to the church where there was to be but one wife. And I think we are in that transition stage in the heathen fields today. I do not think the Apostles put up the standard in that transition stage that they would not have a person in the church who was a polygamist. I think they admitted all the difficulties of the transitory stage and acted accordingly.

F. A. Allum (China) expressed the same concern in this manner:

Concerning the question of polygamy we have taken the stand so far that we will have no such people in our church. But I do not think this is altogether fair. A man is a polygamist before he accepts Christianity. When he accepts Christianity, he is confronted with the question as to whether he shall divorce his second wife. I do not think that is fair to the woman. Divorce means disgrace to the Chinese woman. She is disgraced for life for something which is not of her fault.2

In China, men were not allowed baptism even if they ceased cohabitation with all but one wife. Formal divorce was required.

From Korea, C. L. Butterfield reported that a man must live only with one wife but support a11 others. 3 This was generally the practice in South Africa also as reported by R. C. Porter.

From India, J. S. James reported the position taken by the

Policy and Practice of a Church," A Research Project, Berrien Springs: Andrews University, 1975.

$$
\begin{aligned}
& \text { I"Missionary Round Table," (1913), p. } 5 . \\
& { }^{2} \text { Ibid., p. } 8 . \\
& 3 \text { Ibid., p. } 9 .
\end{aligned}
$$


Christian churches in general assembly: "That when heathen come to the Christian church in a polygamous condition, that they be received as a part of the body, but that they are given no place of preeminence in the church. "1 In India, the SDA church apparently followed the practice of the other mission societies.

The need for arriving at a consensus was keenly felt. It is expressed in the words of L. R. Conradi: "I believe it would be a great thing if our missionaries could come to some kind of agreement even during this meeting so that we could work on the same basis." 2 R. C. Porter, echoing the same wish, stated: "I too wish we would have some understanding about what position we should take. This is a question that is perplexing us and I wish we might reach some agreement, so that we might all work on the same basis." ${ }^{3}$

The issues raised

During the discussion many questions were raised, i.e.:

1. What constitutes a legal marriage? It was felt that this was a matter of concern for the government and that this very vital question was not related to any theological consideration of the problem of polygamy.

2. Is there or is there not such a thing as church privilege without baptism or baptism without church privilege? This problem was given only cursory attention.

3. Can some scriptural basis for the dismissal of a polygamist"s wives be found? This challenge went unmet.
Ibid., p. 11.
${ }^{2}$ Ibid., p. 5.
${ }^{3}$ Ibid., p. 6. 
4. Is a recommendation needed at all, or should the missionary himself in cooperation with his associates deal with each case?

It was the general feeling of those present that some guidelines were needed, but that they were to be used as recommendations only, not as legislation. Individual, difficult cases were to be left to the discression of the missionary and his associates:

In putting this on record it is not a legislative action as though passed by the General Conference, as an order. in force, but it is the consensus of the council of the missionaries. We may still learn more, and may possibly unlearn some things.

The social problems involved received considerate attention. A general feeling of sympathy for the unfortunate victims of the polygamy problem, especially for the women and children, pervaded the discussion. So R. W. Munson (Java) expressed that his wife keenly felt the great injustice done "to the women who in all good honor and faith marry a man, and then have to be divorced and cast off. It is a terrible thing. It is a great wrong to the woman and children." 2

"The Missionary Round Table" discussion concentrated upon the practical aspects of the attitude of the church toward polygamy, namely,

1. How is the matter handled by the various SDA missions?

2. How do other missionary societies treat the problem?

This aspect of the problem was felt to be of great importance.

It seemed to me that an effort on our part to give counsel that will guide our missionaries in the field will be a great

\footnotetext{
Ibid., W. A. Spicer, p. 7.

2 "Missionary Round Table," (1913), p. 10.
} 
blessing to the work and will keep us from putting the standard so low that we will lower the work and put ourselves in a position with the other societies where they will regard us as not even following the instruction of the Bible.?

Amendments to the resolution

During the Missionary Round Table debate, two amendments were made to the proposed resolution:

1. The recommendation that "a polygamist should retain his first wife" generated some discussion among participants. It was pointed out that in some cases the first wife was the widow of the man's deceased father and not considered his real wife. The suggestion was then made that the recommendation read "his first lawful wife." W. A. Anderson then queried what ought to be done if this wife was childless and the second had children, stressing that it was a serious thing to make children fatherless. To this R. C. Porter responded that the only safe rule would be to insist on the first real wife being the scriptural wife. The recommendation was then amended to read "his first lawful wife." 2

2. The status in the church accorded to a converted wife in a polygamous situation was also discussed.

W. A. Spicer questioned the rational of accepting the wife in a polygamous marriage into church fellowship while barring the husband. The various responses voiced from the participants indicated the general feeling that the polygamous husband, having the power and authority, was in a position different from the wife who had no say in the matter of separation.

TIbid., quoting J. L. Shaw, p. 14.

2 "Missionary Round Table," (1913), p. 11. 
After having ascertained that in most fields the SDA church would not accept the wives in a polygamous marriage for church membership, W. A. Spicer made inquiry about the practice followed by other mission societies. The response "other churches would not do it" ${ }^{1}$ settled the discussion. R. C. Porter stated that "the committee agrees to leave out the clause that receives a wife into church membership without separation from her husband." 2

The 1913 recommendation on polygamy

As a result of the deliberations and due to questions raised during the 1913 session of the Missionary Round Table, the committee appointed by the General Conference to study the problem amended its recommendation to read:

WHEREAS, In heathen and Mohammedan lands polygamy is largely practiced.

WE RECOMMEND, That, when a man practicing this custom becomes a Christian, he be accepted into the church on condition that he support all his wives and children, but that he lives only with his first lawful wife as husband and wife. It be further understood that such a convert be not eligible to any office in the church.

In the case of a plural wife accepting Christianity, she be required, as a condition of church membership to separate from her husband, and if possible to obtain his consent, or if the separation can be effected by legal process, that she be privileged to marry again. 3

This amended recommendation was in turn submitted by the Missionary Round Table to the Generat Conference which voted in June 1913 to accept the recommendations as guidelines to the missionaries in the field.

Ibid., p. 15.

${ }^{3}$ The minutes are not available. 
In analyzing the Missionary Round Table discussion of 1913, one notices that no serious theological arguments were presented during the proceedings on the question of polygamy. A solution was sought in consideration of the social injustice to the victims-the wives and the children, the need for arriving at a united practice, and a concern for the standing of the church among other missionary societies.

The non-legislative aspect of the recommendation helped to smooth out differences of opinion. It was a means to overcome some objections and get a vote on the recommendation. Carscallen voiced his opinion:

I feel that our missionaries are safer on the point than this congregation. They understand the cases they have to meet individually. I should not think of voting on this as a law, but as an expression of counsel. I feel willing to vote in favor of it, if we can take it as counsel and then deal with each individual case. 1

Maberly comments that the recommendation itself was not "the consensus of the missionaries involved in the Missionary Round Table discussion in Takoma Park on that June day of 1913, but rather, the most conservative common denominator of that group. ${ }^{2}$

\section{The Missionary Round Table of 1926}

One of the purposes of the 1913 recommendation had been to arrive at a generally agreed-upon practice in dealing with polygamous families in the mission fields. This goal, on a whole, was not accomp 7 ished. When the question of polygamy aga in surfaced in

T"Missionary Round Table," quoting A. A. Carscallen, p. 12. 2 Maberly, p. 34 . 
the Missionary Round Table ${ }^{1}$ discussion of 1926 held during the General Conference Session in Milwaukee, Wisconsin, a variety of practices were noted.

Practices and attitudes in the various fields

The European Division ${ }^{2}$ followed a uniform policy. No polygamists were admitted to baptism. The primary concern of this Division seemed to be the purity of the church and church standards, as well as a concern for a united worldwide stand. E. Kotz commented that they (German East Africa) had refused baptism to polygamists, not on the ground of biblical principle, but because they wanted to uphold what they considered the united counsel of 1913. Although the Division was sensitive to the human and social problems involved in requiring people to break up their polygamous union, it was generally felt that there was no way of compromising with this "stronghold of heathenism." W. T. Bartlett of the East African Field declared:

Everybody must understand that we are out to fight polygamy. .. It is the great evil in which Satan has power. Everybody must understand that our mission village stands absolutely four square against polygamy. . . . We feel that it is absolutely vital to the existence of the Seventh-day Adventist church that we stand against polygamy. 3

This fight to the "bitter end" precluded the baptism of polygamists. In Kenya and Tanganyika, the polygamists were not even

${ }^{1}$ See appendix $B$ for participants.

${ }^{2}$ The mission fields under the juridiction of this Division included: The East African Union Mission, The Ethiopean Union Mission, The West African Union Mission, and the Rwanda-Burundi Missions.

"Missionary Round Table" (1926), pp. 2, 3. 
permitted to live within the mission village. Polygamy was seen as "that evil by which Satan has ensnared the people." Those who did not separate themselves from this condition were "wicked people with no strength to stand," their persistence in this condition was "because of weakness, because of lack of faith." 1

It should be noted that Bartlett followed Carscallen as superintendent of the British East Africa field in 1920. In 1913, Carscallen had cautioned against applying the recommended rule to the letter in Africa, stressing that he did not think people involved in difficult polygamous cases should be kept out of the church. Apparently this view did not change after the 1913 discussion. So it would seem that the two consecutive administrations in British East Africa represented two opposing views and policies in that area.

In Southern Asia Division, polygamists were admitted to baptism (at least in India). A. H. Williams, secretary-treasurer of the Division, stated his view on the matter:

We have always given the answer that it is not necessarity right to require a man to put away his second and subsequent wives, but that even with those plural wives, he might be admitted into church membership, but not to church office. ${ }^{2}$

The practice of the Southern Asia Division then was in direct opposition to that of the European Division.

The Far Eastern Division seemed to have no uniform policy or practice on the polygamy issue. Three representatives from this Division participated in the 1913 Round Table discussion, but during the 1926 discussion they made no allusion to the 1913 recommendation. 
The African Division ${ }^{1}$ did not have a uniform policy on the subject of polygamy. In some areas, polygamists were baptized while in others they were not. W. H. Anderson speaking for his field, Angola, explained:

The people right out of heathenism never had a chance for the gospel. These men came to us, polygamists came asking to be baptized. We baptized them, leaving them to choose for themselves whether they are to put away their wives or not. After the message has come to them, the young men growing up, we do not permit them to become polygamists. We turn them out of the church if they do. 2

G. A. Ellingworth, speaking for another field within the same Division (Nyassaland) noted that "the rule we have been following has been a varied one. In some fields, we baptize those who are polygamists, in other fields we refuse to baptize them. " 3

Decisions for or against baptism was apparently made by some church administrators on the basis of the social situation in different fields.

We all felt that something ought to be done for the polygamists who had taken several wives and had large families. In some fields it is a very easy matter for the man to give his wife a present of a dollar or two and ask her to leave. On the other hand there are one or two fields where if a woman is put away for any reason whatever, no one will have anything to do with her. For that reason we agreed to compromise somewhat, and we agree to baptize those who come to the knowledge of the church straight from heathenism; but, in order to keep the church pure and free from every taint, we do not accept them into full church fellowship, although they can enjoy church privileges, yet they could not be received into full church fellowship where they could hold office, which is according to the Scriptures. 4

The mission fields administered by this Division were the following: The South African Union Conference, Zambezi Union Conference, the Congo Union Mission.

$$
\begin{array}{ll}
2 \text { "Missionary Round Table" (1926), p. } 1 . \\
{ }^{3} \text { Ibid. } & 4 \text { Ibid., p. } 2 .
\end{array}
$$


Ellingworth's observations must be seen against the background of variations in African social systems, as noted in chapter 2. Among matrilineal groups, marriages are generaliy unstable and divorce carries little stigma, while among patrilineal people divorce, being almost non-existent, carries severe social sanctions and possibly even ostracism. Problems in regard to separation would therefore be more obvious to missionaries working in patrilineal societies than for those working among matrilineal groups. Thus, if one considers only the social difficulties involved in the separation of polygamous families, there is not necessarily any contradiction among the following statements:

Say the husband retains only one wife. . . Then all the other wives put away are classed as harlots, and the children become illegitimate. This is the law. Do we want to inflict that upon the women and children?

It is customary in Africa [i.e., the remarriage and dismissal of wives]. There is nothing considered out of place in it at all. A woman can marry as many times as she may.?

And really, brethren, in some parts of Africa that is not so bad [dismissal]. It is not so serious there, as it would be in this country. ${ }^{3}$

The correctness of such statements would largely depend upon the societies to which the speakers referred. Africa is a vast continent with a multitude of ethnic groups and social systems. Within the Territory of the African Division there were matrilineal societies, with notably unstable marriages, as well as patrilineal groups in which the dismissal of wives presented grave

\footnotetext{
T"Missionary Round Table" (1926), quoting W. H. Anderson, p. 7.

2"Missionary Round Tab7e" (1926), quoting R. C. Porter, p. 5.

3"Missionary Round Table" (1926), quoting W. A. Spicer, p. 5.
} 
social consequences for the people concerned. Apparently allowance was made for those differing situations. The Division had attempted to coordinate its practice during a meeting ${ }^{1}$ of missionaries representing the various fields. This resulted in the formulation of the Division working policy as of January $1926 .{ }^{2}$ The statement of this policy on polygamy is remarkabiy similar to the resolution voted by the Annual Council four years later. It is logical to conclude that the 1930 policy was modeled upon the 1926 policy of the African Division.

The difference in practice between the European and African Divisions

The European Division also had areas with strongly patrilineal societies, particularly in East Africa, under its administration. Although the Division was sensitive to the human problems involved in the separation of families, it did not change or modify its stand on the issue. Those two Divisions (European and African), had similar social circumstances within their territories, yet their policies were directly opposed to each other.

The difference in practice between the two was probably due to two factors: (1) There was in the European Division a tendency to apply the 1913 recommendation more legalistically, seeing it as a means of providing a unified practice and higher church standards. Thus Conradi, superintendent of the European

'Maberly makes a reference to this meeting, but search for material relating to this meeting has proven fruitiess.

${ }^{2}$ See General Conference of the Seventh-day Adventist Church (African Division), "Plans and General Policies adopted with Reference to its Work," January 1926 (Washington, D.C.: General Conference of SDA Church, Archives), pp. 7, 9. Appendix C. 
Division, who in 1913 had expressed his doubt concerning the justification of breaking up a polygamous family, apparently counseled Kotz to follow the 1913 recommendation closely. In spite of his formal adherence to this recommendation, Kotz's personal views seemed to be in accordance with that of the African Division. During the 1926 discussion, he referred to the necessity of having to refuse baptism to genuinely converted polygamists as one of his saddest experiences in Africa, stressing that he had done so, not on biblical grounds but because he did not want to go against the church stand in this matter. The African Division, on the other hand, seemed to view the 1913 recommendation less as policy and more as counsel to be adapted to the particular situations in the various fields. They did, however, consider their stand as something of a compromise between compassion for the innocent victims of polygamy and concern for church standards.

(2). It seems quite clear that certain individuals must have strongly influenced the attitudes of the two Divisions towards the issue. Thus Bartlett, an outspoken adversary of baptism for polygamists, had replaced Carscallen in East Africa. Men like Anderson and Ellingworth might have influenced the stand of the African Division in this matter. It should also be noted that Branson, apparently the chief architect of the 1930 resolution of the General Conference, had been president of the African Division since 1919.

So, although one of the main goals of the 1913 recommendation had been to provide a common standard for the world church, no such ideal had been achieved. The non-legislative character 
of this resolution had left the fields in Africa with freedom for adaptation to local situations, and for personal views on the issue. Thus, on the eve of the 1926 discussion, we find that two Divisions ${ }^{1}$ were admitting polygamists to baptism while the rest of the world field apparently was not.

The 1926 recommendation on Polygamy and marriage relationships

During the 1926 discussion, there was a clear divergence of opinion among the participants regarding the baptism of polygamous converts. W. E. Read suggested that "the matter would be given further consideration" and that a "small committee or commission be appointed." 2 It was "moved that a committee be appointed to give careful study to the question of polygamy, and the stand that should be taken in regard to it. ${ }^{3}$

The problem of tangled marriages in Catholic countries, where persons not legally divorced had separated and started new families, was also to be considered by this committee. It is, however, regrettable that there is no record of the discussions of this committee. One can refer only to the minutes of the action of the General Conference in session: "Voted to adopt the resolution on polygamy and marriage relationships, formulated as a result of discussions in the Missionary Round Table during the

${ }^{7}$ The Southern Asia and the African Divisions.

"Missionary Round Table" (1926), p. 5.

${ }^{3}$ Ibid., quoting J. W. Westpha1, p. 6. 
Conference Session." 1 The resolution reads:

Whereas. The practice of polygamy on the part of many races for whom we are laboring is in itself a challenge to Christian principles, and constitutes a ground of compromise if permitted in the Christian church; therefore, -

We recommend, 1. That great care be used in the examination of peoples in heathen lands for entrance into the church, and as this examination relates to this practice, we would advise the following:

(a) That in no case should a man living in polygamy be admitted into the fellowship of the church.

(b) That preceding his entrance into the church a sufficient time of probation be given him to test out his sincerity in separating himself from this practice. 2

This resolution represents a victory for the most conservative stand on polygamy ever taken by the Seventh-day Adventist Church. It reflected no consideration for the social problems involved. There was no reference made in this policy to the wives and children of the polygamous convert. Polygamy was an unmitigated evil to be destroyed at any cost.

The recommendation, voted at the same time, concerning tangled marriages in Catholic countries ${ }^{3}$ reflects quite a different attitude.

In many cases after careful investigation we cannot advise them to separate and thus break up their home and present relationship, for this would only make conditions worse, and knowing that the Gospel truth does not come to the people to make conditions worse, but better, and that God receives a sinner where he is found and saves him when he repents and turns to him. 4

${ }^{1}$ General Conference of Seventh-day Adventists (Washington, D.C.), Minutes of the Sixth Session of the General Conference, June 13, 1926, Vol. 12, bK. 1, appendix D.

${ }^{2}$ Ibid.

${ }^{3}$ For the full recommendation on tangled marriages see appendix $D, p .14$.

${ }^{4}$ General Conference, Minutes of Sixth Session, June 13, 1926. 
There is no theological justification for treating the tangled marriage situation with greater leniency than polygamy. In a biblical sense, the former constitutes adultery, while the latter is legal marriage. In the case of the tangled marriage, there is not even social or juridical justification. Here Maberly rightly observes:

In Catholic countries the tangling of marital alliances would seem to be undertaken against some conscience and with the tacit disapproval of society, and against the laws of the church and land. In many countries polygamy is contracted with a clear conscience, with the blessing of the society. It would seem that there would be more room for sympathetic treatment of the latter cases. 1

Both situations with their complex human problems merit sympathy and consideration, but socially, juridically, and theologically, the case of the converted polygamist is the strongest. However, the tangled-marriage situation is closer to Western man's own frame of reference. It is, therefore, easier to feel empathy with such a situation than with the exotic aspect of polygamy. Only by understanding the pervasive influence of culture can the above decision be understood.

Reflections on the resolution of 1926

In the 1926 debate on polygamy, the very vital question of scriptural support for the practice of refusing baptism to polygamists was again voiced. "I would like to ask if it is contrary to the word of God. ${ }^{2}$ No serious theological argument was presented in response to this challenge. The main concern pressed

\footnotetext{
TMaber1y, pp. 67, 68.

2"Missionary Round Table," (1926), quoting C. F. Enoch, p. 2.
} 
forward at the meeting seemed to be the urgency of arriving at a unified stand on the issue and the need of maintaining a high church standard.

Comparing the recommendation voted on June 13, 1926 with the discussion preceeding it, one cannot but feel that the resolution was not an expression of missionary consensus. It would seem that most of the missionaries participating in the 1926 conference had an open attitude toward the problem of the polygamous convert and were sensitive to the social and emotional problems resulting from breaking up the polygamous family. If the discussion is regarded in the light of prevailing attitudes of other mission societies at the time, the generally openminded attitude of the SDA missionaries (both in the 1913 and 1926 discussions) becomes even more pronounced. In 1913 the recommendation had passed mainly because it was considered non-legislative. This was not the case with the 1926 resolution which was obviously meant to have uniform application in the world field. It would seem then that the 1926 policy was a definite victory for the conservative view represented by the European Division.

The 1930 Resolution on Polygamous Marriages in Heathen Lands

On August 16, 1926, at the Summer Councit, the European Division re-emphasized its stand and "voted that the Mission's Secretary be instructed to pass on to all our missionaries the action taken at the General Conference Session . . covering the question of polygamy, as our policy governing this matter."

${ }^{1}$ European Division Minutes, Summer Counci1, August 16 , 1926. See appendix E, p. 6. 
While the 1926 resolution re-affirmed the European Division in its practice, it meant a change of policy in the African Division. Elder W. H. Branson had been the president of this Division during the years when it had allowed the baptism of polygamists as probationary members. Apparently neither he nor others in the African Division were totally convinced of the justice of the 1926 resolution. A manuscript written by J. I. Robison in $1928^{l}$ argues forcefully against the policy of breaking up the family, stressing the "hardships and the degrading consequences that the Native women endure who are forced to give up their homes, and often times their children, when they are put away by their husbands because of his having accepted the Christian faith." ${ }^{2}$

Although records dealing with this problem seem to be practically non-existent, it is possible that Robison's manuscript on polygamy indicates a very unsettled situation covering the polygamy question in the field. In any case, the General Conference felt it was necessary to appoint a Committee on Polygamy among Primitive Tribes. The committee ${ }^{3}$ gave its report, not before a full General Conference Session, but during the Autumn Council

1J. I. Robison's manuscript on Polygamy is undated. Review and Herald Obituary January 25, 1962 dated his return to South Africa as 1926. Robison mentions in his manuscript that "a little more than two years" had passed since his return to South Africa. See Robison Obituary, appendix F.

${ }^{2} \mathrm{~J}$. I. Robison, "Manuscript on Polygamy" (Washington, D.C.: General Conference of the Seventh-day Adventist Church, Archives, ca 1928). p. 13.

${ }^{3}$ Members of the committee were: E. E. Andross (President of the Inter American Division, A. V. 01 son (President of the newly organized Southern European Division), and W. H. Branson (African Division). 
held October 28-November $3,1930^{\circ}$ in Omaha, Nebraska. No records of the discussions in the committee nor of the report it gave before the Autumn Council are available. All we can ascertain is that the resolution they offered was passed during the Fifty-Ninth Meeting of the General Conference Committee on November 3, 1930. The resolution with the introductory remarks reads as follows:

The officers in session before the Autumn Council made careful study of the problems of polygamy as met in certain heathen fields. They offered the following resolution, which was passed:

WHEREAS, The message finds people in certain heathen lands living in a state of polygamy, and where tribal customs subject a cast-off wife to lifelong shame and disgrace, her children also becoming disgraced thereby, it is,

RESOLVED, That in such sections, persons found living in a state of polygamy at the time the gospel light comes to them, and who have entered into plural marriages before knowing it to be a custom condemned by the word of God, may upon recommendation of responsible field committees be admitted to baptism and the ordinances of the church, and may be recognized as probationary members. They shall not, however, be admitted to full membership unless and until circumstances shall change so as to leave them with only one companion.

This action merely contemplates the recognition of a condition which in some places cannot be changed without resulting in great injustice to innocent persons and is not to be construed as endorsing polygamy in any way. Anyone entering into a plural marriage relation after receiving a knowledge of the truth should be regarded as living in adultery, and dealt with by the church accordingly. A man who has apostatized from the truth and who during the time he is in apostasy, enters into plural marriage may not be received aga in into any church relationship untit he puts away the wives taken during his apostasy and in every way brings forth fruit meet for repentance.

In countries where separation of families can be arranged without injustice being done to innocent parties only one wife should be retained, but we recognize the right of the man to choose the one to be retained.

"Actions of the Autumn Counci1" (Omaha, Nebraska, October 28-November 3, 1930), pp. 74-75. See appendix G. 
It is reasonable to believe that Elder Branson was the chief architect of this resolution which is similar to the 1926 policy of the African Division.

The 1930 General Conference official policy strongly expressed the firm belief of the church in the monogamous ideal, but recognizing the great social problems and human suffering resulting from forced separation of polygamous families in many societies, it made concession for such cases. A polygamist could upon the recommendation of the responsible field committee be admitted to baptism and the ordinances of the church. Such members, however, were to be considered as probationary members as long as the polygamous situation remained.

The 1930 resolution also left the choice of which wife to retain with the man. It specified that the concession of baptism was valid only for a man already finding himself in a polygamous situation when accepting the Gospe1: Any wives married during a subsequent apostasy were to be put away before re-acceptance to the church.

The Background for the 1941 Resolution on Polygamy

The 1930 resolution apparently was not adopted by all the world fields. The Northern European Division ${ }^{1}$ continued to follow the 1926 policy. In 1939, the African Division also reverted to the 1926 resolution. ${ }^{2}$ It is significant to note that $W$. H. Branson

${ }^{1}$ This Division was organized in 1928.

${ }^{2}$ See the policy in appendix $H$. 
left South Africa in 1930 and became the president of Section II of the Central European Division ${ }^{1}$ in 1938. A year later, the same Division adopted the 1930 General Conference policy. ${ }^{2}$ A very practical problem arose in applying this policy in Tanganyika. The adjoining territory of Kenya, under the leadership of the Northern European Division, still followed the 1926 policy on polygamy.

A letter written May 16, 1940 by J. I. Robison, ${ }^{3}$ Secretary of the Northern European Division, reported to E. E. Dick, then Secretary of the General Conference, that word had been received from Kenya indicating that the Central European Division, Section II, had introduced into neighboring Tanganyika a new policy regarding polygamy: Robison requested the General Conference to urge the Central European Division not to implement the 1930 General Conference policy in Tanganyika until the matter could be given further study by the General Conference.

I am sending you a copy of the present policy as operating in the Southern Africa Division which also is the policy that we have been following in our East Africa mission fields. If however the Tanganyika territory should introduce a more liberal policy toward polygamy, it will certainly become known to our workers in East-Africa and is bound to create misunderstanding and result in breaking down the standards. 4

This Division was organized in 1929. Section II represents its mission fields.

${ }^{2}$ See appendix I for the policy.

3 J. I. Robison wrote a manuscript on polygamy in 1928 (ca) in which he argues for the baptism of polygamists. According to his letter to E. E. Dick of the General Conference, he would seem to have changed his position on the issue. It is significant to note that Elder Bartlett, who had been firm in his stand against polygamy during the 1926 discussion, was presently the Sabbath School and Missionary Volunteer Secretary of the Northern European Division.

${ }^{4}$ Letter Robison to Dick, May 16, 1940. 
Robison admitted that the policy introduced by Central

Europe was in harmony with that of the Southern Asia Division ${ }^{1}$ and also with the action of the Autumn Council of 1930 . He questioned, however, the validity of the latter action, writing: "The General Conference in Session in Milwaukee went on record as follows:

That in no case should a man living in polygamy be admitted into the fellowship of the church;

This action was taken when representatives from nearly all of our mission fields in the world were represented and evidentiy expressed the general feeling of our mission directors at that time. At the 1930 Autumn Council the question was evidently restudied and provision was made for people living in a state of polygamy to be baptized on certain conditions. In our study of the question today, we have wondered whether or not a decision taken by the General Conference in Session with representatives from all parts of the world present, should have been reversed by an Autumn Council wi thout representatives from our mission fields being present. ${ }^{2}$

E. D. Dick informed J. I. Robison in a letter of June 9, 1940 that

At the present time there are few of our General Conference group here at headquarters and it does not seem we 11 for us to attempt to tackle a large problem of this kind with the working force which we have. I shall be glad to see that the matter is listed for study when more of the men are back at the headquarters. 3

In a letter of June 20, 1940, Robison enclosed for the consideration of the General Conference Committee a formal statement of the problem. ${ }^{4}$ This formal statement (Memorandum) received from the Northern European Division resulted in recommendation by the

${ }^{1}$ See appendix $H$.

2Letter Robison to Dick, May 16, 1940. (Italics for emphasis.)

$3_{\text {Letter June } 9,1940 .}{ }^{4}$ See appendix J. 
General Conference committee that a sub-committee of the Home and Foreign Officers make a study of the problem. This new committee began its work on October 9, 1940, and reported to the Home and Foreign Officers the following day that a memorandum from the North American Division included a request that the recommendation of the committee be presented to the General Conference in full session. This request was accepted by the officers. 1 The subcommittee presented its report to the Home and Foreign Officers at a meeting, May 20, 1941, at which time it was amended. There is no record of the amendments being made by the Home and Foreign officers. The actions from that board simply state that "The subcommittee presents its report and in its amended form was adopted to be submitted direct to the session from this group. ${ }^{2}$ The amended report was accordingly submitted directly to the session and voted without further amendments at the Tenth Meeting of the General Conference, June 5, 1941, San Francisco, as policy of the General Conference.

The members of the subcommittee were a11 men with varied experiences in mission work where polygamy was a burning issue. ${ }^{3}$ Unfortunately there are no records preserved of the committee's discussions. One can only surmise that it dealt primarily with the concrete practical aspect of the problem especially as it related

${ }^{1}$ See actions supplied by the General Conference Archives, October 10, 1940.

${ }^{2}$ Actions of the Home and Foreign Officers' meeting, May 20, 1941, San Francisco. See appendix K.

${ }^{3}$ See appendix $M$ for the list of participants. 
to the adjoining fields in East Africa pursuing divergent practices in regard to the polygamy issue.

The primary concern of the committee, then, was to arrive at a worldwide united standard, a standard that would be more than just a guiding principle open to interpretation and adjustments. As 0 . Montgomery's introductory remarks point out: "These recommendations really take us back to the 1926 principle stated in a fuller, broader way. "T Montgomery ${ }^{2}$ al so stressed that "our council were united in the adoption of these series of recommendations as being the strongest and clearest and the safest policy to follow. ${ }^{3}$

The 1941. Policy of the General Conference reads as follows:

WHEREAS, It is clearly God's plan that man should live in a state of monogamy, that is, that a man should have only one living wife; and

WHEREAS, Any contravention of this plan results in confusion and the lowering of the moral standards that should govern human society, and especially the church of Christ; and,

WHEREAS, the practice of polygamy on the part of many nonChristian peoples for whom we are laboring is in itself a challenge to Christian principles, and constitutes a ground of compromise if permitted in the Christian Church;

WE RECOMMEND, 1 . That a man found living in a state of polygamy when the gospel reaches him, shall upon conversion be required to change his status by putting away all his wives save one, before he shall be considered eligible for baptism and church membership.

2. That men thus putting away their wives shall be expected to make proper provision for their future support, and that of their children, just as far as it is within their power to do so.

${ }^{1}$ See appendix $L$ for Montgomery's Explanatory remarks.

${ }^{2}$ Montgomery was not a member of the committee, but was apparently asked to be its chairman.

3Montgomery's remarks on June 5, 1941. 
WHEREAS, The message finds people in certain countries living in a state of polygamy, where tribal customs subject a wife who has been put away to lifelong shame and disgrace, even to the point of becoming common property, her children also becoming disgraced thereby;

WE RECOMMEND, 3. That in all such cases the church cooperate with the former husband in making such provision for these wives and children as will provide for their care and protect from disgrace and undue suffering.

4. That we recognize the right of a wife who has been put away by a polygamous husband to marry again.

5. That wives of a polygamist, who have entered into marriage in their heathen state, and who upon accepting Christianity are still not permitted to leave their husbands, because of tribal custom, may upon approval of the local and union committees become baptized members of the church. However should a woman who is a member of the church enter into marriage as a secondary wife, she shall be disfellowshipped and shall not be readmitted to the church unless or until she separates from the polygamous husband.

6. That it is understood that the above policy supersedes a11 previous policies on polygamy.

The 1941 policy was a victory for the conservative stand on the issue, a stand represented by the European Division during the entire period of 1913-1941. In its general principle, it bore resemblance to the 1926 policy, although it was considerably more humane in its approach. The responsibility of the man for his dismissed wives was stressed, so also were the rights of a dismissed wife to remarry. Wives unable to obtain separation from their husbands were accepted for baptism. Reference was made to monogamy as being God's intended ideal. But, as in the 1926 resolution, polygamy is seen as "a challenge to Christian principle" constituting "a ground for compromise if permitted in the Christian church." The 1941 policy was to supersede all previous policies on polygamy. 
The policy of the Seventh-day Adventist Church on polygamy, then, had moved from calitious guideline in 1913 to firm legislation in 1941 .

Developments after 1941

The SDA church later re-emphasized its 1941 policy. An action of the Officers' meeting, May 8, 1949 reads as follows:

Inquiry Re Polygamy and Marriage Relationships

AGREED-adyising that in reply to an inquiring from Brother Sorensen of the Far Eastern Division concerning statements made on this subject at the Fall Councils of 1926 and 1930, it is pointed out that the statement found on pages 93-95 of the current Working Policy booklet presents our present position regarding these matters. 1

A slight hint of possible accommodation in severe cases was noted in the report of the ad hoc committee presented on August 2, 1974, to the General Conference Administrative Committee. On September 19, 1974, the latter voted to request the members of the ad hoc committee, W. Duncan Eva and B. E. Seton, to counsel with R. R. Frame in regard to the question on polygamy raised by the Australasian Division. The letter, while endorsing the earlier stand on polygamy, nevertheless noted:

Where there are apparently insuperable difficulties in fulfilling these requirements it might be advisable with Division concurrence with the principle, to arrange for the candidate's baptism yet to withhold granting of church membership. Such procedure places a man in a saving relationship to Christ while maintaining standards for church membership.?

In 1978, the question of polygamy surfaced again during

${ }^{1}$ See Actions supplied by the General Conference, Archives, May 8, 1949.

${ }^{2}$ Ad Hoc Committee report on Polygamy Question, August 2, 1974. 
the Administrative Committee meeting of May 25, 1978. The following notation was made:

From Administration/ ADCOM to HOO AC 78

(A 2517) C 85 Polygamy - Policy - Study

Recommended, to study Policy Matters on Polygamy (a e g $)^{1}$

The 1941 stand was re-emphasized at the Home and Overseas

Officers' meeting October $\underline{8}, 1978$ where it was noted:

From Secretariat/ HOO 78AC to AEG

(A 2517) C 84 POLYGAMY - POLICY STUDY

VOTED, to record that the General Conference Working Policy statement C 85 Polygamy is thought to be satisfactory. 2

This then is where the matter rests at the present time.

Attempts to Accommodate the Policy

to the Practical Situation

in various fields

Stating the policy is one thing; applying it on the human level is another. This fact has become increasingly clear during the forty years since the policy was put into effect. In the fields, various ways of coping with the problem have been considered.

Fringe membership

In societies where dismissal of the wives has presented grave social problems, it has often been a tacit understanding that the best solution is not to press the issue but rather to encourage the convert to follow the Christian way of life without baptism, in the hope that this complex social problem would find a solution in

\footnotetext{
IAdministrative Committee Meeting, May 25, 1978.

${ }^{2}$ Home and Overseas Officer's Meeting, October 8, 1978.
} 
God's own time. An insight into the African social background, however, makes one realize that this is not a satisfactory solution. In Western culture, the essential unit is the individual; in African society, it is the group. It is not so much the individual who confers worth on the group, as the group which gives the individual his/her status and worth. A person belongs not only to his parents but to his total extended family. "Life has been transmitted to him by his family, and it is by it that he continues to live. If he cuts himself from the family he has become a dead branch." "1

This kind of social organization results in strong group solidarity and a communal spirit; inasmuch as the extended famity substitutes for often non-existent public welfare programs.

Western culture has cultivated the need for being alone, the need for time and space for each individual. The traditional African lives always with others. Wanting to cut himself off from the group even for a few moments is inconceivable. The thirst for union, communion in every aspect of life--social as well as religious--is an inseparable part of the tribal African character.

Because of his cultural background, the converted African has a greater need for identification with the church than has his Western counterpart. The church is part, not only of his religion but also of his social needs. The two are inseparable in the African mind.

The acceptance of Christianity often separates the African

'Guerry, p. 19. 
from his tribal community. This is a difficult experience in any society, the Western included. In view of the previous discussion on kinship, it should be obvious what a traumatic experience this is for an African. The church here has to become a psychological and social substitute for the family unit. It is a fact, not fully realized by missionaries, that the church must minister to the psychological need for communion and identification in these societies to a far greater extent than is usual in Western countries. Instead of receiving added support, however, the polygamous convert is denied even simple membership. Often being at odds with his own family by his acceptance of Christian belief and practice, he is at the same time not fully accepted into the community of bel ievers.

Christianity stresses growth in maturity through the sanctifying influence of the Holy Spirit and through nurture and growth in the fellowship of believers. The nurturing and communal aspect of the Christian faith so relevant to the convert is, however, denied to the man accepting Christ while bound in a polygamous situation.

Membership without baptism or baptism wi thout membership

Attempts to solve the polygamy issue have given rise to the suggestion of membership without baptism. So, J. R. Rogers suggested: "What serious objection would there be in a case like that (polygamy) to take the people into the church without baptism. Let them have al1 the privileges of the church without baptism, until 
they can get their troubles settled. I often follow that practice."

P. K. Westphal advocated the opposite: "It seems to me I would prefer to baptize them and permit them to partake of the Lord's Supper, but not take them in as church members. "2

F. H. De Vinney objected: "I think baptism itself takes them into the church." 3

Theologically, we must agree with the last statement. The New Testament presents the church as one united body, with Christ as its head ( 1 Cor 12:27; Eph 1:22, 23; Col 1:18-24). Being born again by the Holy Spirit (John $3: 5,6,8$ ), the convert is baptized into this body (1 Cor 12:13). E. G. White notes:

The Father, the Son, and the Holy Ghost, powers infinite and omniscient, receive those who truly enter into the covenant relation with God. They are present at every baptism, to receive the candidates who have renounced the world and have received Christ into the soul temple. These candidates have entered into the family of God and their names are inscribed in the Lamb's book of 7 ife. 4

Therefore, the new birth experience qualifies the repentant sinner for baptism and church membership.

\section{Concluding Remarks}

The policy as it evolved is a child of the concern of the church for unity and church standards. Theological considerations seem to have been virtually absent from the deliberations through

\footnotetext{
1"Missionary. Round Table" (1926), p. 6.

${ }^{2}$ Ibid., p. 8.
}

${ }^{4}$ Ellen G. White, MS 271/2, 1900, Ellen G. White Research Center, Andrews University, Berrien Springs, MI. (Emphasis supp 7 ied.) 
the entire period from 1913 to the present. ${ }^{1}$ There is no doubt that those involved in formulating the various policies were earnestly desiring to follow God's Word and will. Upholding the Word of God was for them of prime importance. But if polygamy was equated with adultery, a concept shaped by a Western cultural interpretation of the custom, then theological study became superfluous. The Bible clearly condemns adultery. The participants formulating the policies, then, were caught between their desire to uphold the monogamous norm to which they were unanimously committed and their sensitivity to the social difficulties caused by the separation of the polygamous families.

Social awareness and compassion seem to be the determining factors accounting for the general openminded attitude of SDA missionaries toward polygamy as seen against the prevailing attitude of other missionary societies in the early twentieth century. Thus more liberal ways of dealing with the problem emerged in the various mission fields culminating in the attempt in 1930 to formulate this attitude into a uniform policy. The 1930 exceptional policy was based squarely on social awareness. Such a basis, however, proved too fragile and was too vulnerable to the rhetoric from the conservative elements within the church who emphasized that polygamy was an evil to be destroyed at any cost.

The conservative view prevailed culminating in the firm legislation of 1941. But the tension between the conservative view

I Since there is no record of the 1941 discussion nor of those of 1974 and 1978, it is impossible to exclude the possibility of such considerations. The above conclusion is made in reference to available documents only. 
and the social awareness and compassion of the church has continued to exist. This has resulted in attempts to sidestep the issue by proposing solutions like fringe membership or baptism without. membership and vice versa. So the problem of the polygamous convert is by no means resolved within the SDA church.

During recent years, cultural and anthropological knowledge has increased--knowledge which was not available to the men who shaped the attitudes of the church in the early years. As a result, many churches and mission societies have modified significantly their stand on the issue of polygamy. During the same period, however, the position of the Seventh-day Adventist Church has not changed. 
CHAPTER $V$

EVALUATION, RECOMMENDATIONS, AND

CONCLUSION

This chapter is concerned with the evaluation of the policy of 1941, in light of the preceding discussions, and attempts to suggest alternative solutions regarding the polygamous convert.

\section{Evaluation of the 1941 Policy}

WHEREAS, It is clearly God's plan that a man should live in a state of monogamy, that is, that a man should have only one living wife; ...

So commences the policy as presented to the May 1941 meeting of the Home and Foreign Officers. However, there is no direct scriptural condemnation of polygamy. Textual arguments against polygamy are developed by inferences only and rest on assumptions that are not self-evident. There is a real danger of reading into the Bible what one expects to find there, and such expectations may be shaped by one's own cultural tradition. The polygamous rorm then cannot be tested by reference to specific texts but only as seen within the wide scriptural teaching on marriage. It is argued in chapter 2 that polygamy has all the jural and anthropological criteria of a legal marriage, and that there is no biblical support for classifying polygamy as adultery and/or

\footnotetext{
${ }^{1}$ See page 141 above.
} 
fornication. By testing the polygamous form of marriage against the biblical teaching on marriage, it is concluded in chapter 3 that polygamy clashes with the full ideal of Christian marriage. Marriage, being the ideal form of human relationship, illustrates the transcendental truth of God's covenant relationship with man. Therefore it must be patterned upon the ideal which God established at the dawn of creation.

Polygamy with its underlying fertility oriented and procreational thought pattern is a distortion of God's original plan for the marriage institution. It is one of the results of man's fallen state and his struggle for survival. The church, therefore, must inevitably promote institutional monogamy rather than institutional polygamy.

The theological principle underlying the introductory statement of the policy, then, is biblically sound, but the application of basic theological principles to a situation so ethically ambiguous and within a culture so different from that of the policy makers' own is indeed a difficult task. And it is in the practical application of the theological principle that the policy exhibits certain inconsistencies. These are discussed briefly below:

Resolved, 1. That a man found living in a state of polygamy when the Gospel reaches him, shall upon conversion be required to change his status by putting away a 71 his wives save one, before he shall be considered eligible for baptism and church membership. 1

It is pointed out in chapter 3 that divorce is also a distortion of God's original purpose with the marriage institution.

' See page 141 above. 
It is a pale emblem of the final "casting off," the absolute separation of the unregenerated man from God's saving grace. Divorce also $i 17$ ustrates the severance of a covenant relationship. God's attitude toward it is forcefully expressed in Mal 2:14-16; Matt 19: 9; and Mark 10:11. The requirement that a polygamist must divorce his wives, therefore, has no theological preference over the acceptance of polygamy. Considered from a theological point of view, the polygamous convert does not improve his standing by dismissing his wives. Quite to the contrary, divorce here adds liabilities to his case by causing him to violate Christian principles such as justice, mercy, peace, and love.

Because of man's fallen state, situations may arise in which strict adherence to a biblical ideal might cause violation of other Christian principles. Paul in 1. Cor 7:10-18 made concessions in such cases. To maintain the peace was, according to the Apostle, a decisive factor in the way the new convert should deal with his/her spouse. One may ask if the principle of peace is being served when the breaking up of a polygamous family causes social and emotional upheaval and, at times, even necessitates intervention by customary or civil courts (see chapter 2, part 3).

Thus, requiring a polygamist to dismiss his wives before he may be baptized and enjoy church membership and fellowship would not be a just solution to the polygamy problem. The preference of divorce over polygamy has no foundation in Scripture; it is culturaliy conditioned.

The polygamist caught between the claims of indissolubility and monogamy remains fully within the reach of God's grace. He 
stands in an entirely different position from a man who becomes polygamous after his conversion. The latter is "sinfully disobedient"--willfully rejecting God's revealed will, while the former is "sinfully obedient"--desiring but unable to do God's will. Baptism of the polygamist, therefore, is possible in accordance with the doctrine of justification by faith (Gal $3: 11$ ).

Theologically, the polygamous convert stands much in the same situation as a man divorced and remarried before his conversion. Biblically, the second marriage is an adulterous relationship (Matt 19:9). The church does not require such a person to return to his first wife as a prerequisite for baptism. The text in Acts 17:30 would apply both to the man divorced before his conversion and the polygamist: "The time of ignorance God overlooked, but now he commands al1 men everywhere to repent". (RSV).

Hastings sums up the polygamy-divorce problem thus:

To end a polygamous marriage in the name of Christ, who said nothing explicitly to condemn it, at the expense of effecting a divorce, which Christ explicitiy forbade, is to pay too high a price to achieve a theoretical conformity with one part of the Christian marriage pattern. Equally, to say that as a consequence it is impossible for a polygamist to be baptized, if he sincerely believes in Christ, wishes to be a full member of the church and to do all that is right, is to say too much when we have no explicit scriptural foundation for so doing. 1

According to the text of Paul in 1 Cor $7: 15$, a new convert is not bound to his unbelieving partner if the latter desires to leave him, but, as Paul stresses, "if any brother has a wife who is an unbeliever, and she consents to live with him, he should not divorce her" (1 Cor 7:12). This would indicate that there is no scriptural support for a forced separation of the spouses.

1Hastings, p. 77. 
The wording of the recommendation above is somewhat unfortunate. It gives the impression that a man's wife is more or less on the level with the rest of his goods and chattels which can be abandoned at wi11. The church must be sensitive to the testimony it renders regarding its beliefs in basic human equality and the dignity of womanhood--especially in African and many other third world countries.

Resolved, 4. That we recognize the right of a wife who has been put away by a polygamous husband to marry again. 1

The right of the dismissed wife to marry again may be questioned on theological grounds. This statement is correct only if polygamy is considered as an adulterous relationship. If, to the contrary, the polygamous union is a legal marriage, the wife would still be bound to the marriage after dismissal, and by remarriage would commit adultery (Matt 19:9).

Seen in the context of African social systems, a remarriage is not always possible. In a matrilineal society there would be little problem in regard to remarriage. But in strongly patrilineal societies where divorce is almost impossible, physical separation from her husband would not give a woman freedom to marry again. Children she might bear in a subsequent (irregular) union would belong to the lineage of her legal husband. Since the rule of exogamy usually is in force among patrilineal groups, the relationship of the woman to her own lineage is often cut off by marriage. Upon separation from her husband, therefore, she would have nowhere to turn. Prostitution has often been the result of such severe cases.

\footnotetext{
${ }^{1}$ See page 141 above.
} 
2. That men thus putting away their wives shall be expected to make proper provision for their future support, and that of their children, just as far as it is within their power to do so. 1

Here, the policy stresses the father's responsibility of caring economically for his dismissed wives.

It was noted in chapter 2 that divorce in a matrilineal society makes little change in the economic situation of a woman. In most patrilineal societies, however, the woman is totally dependent on the husband and his clan. In a rural setting, she would live within the compound of her husband where she would help cultivate the land. Removed from this setting, there would be no room for her within the tightly knit structure of the patrilineal society. Should the polygamous convert support such a dismissed wife, he must be a very wealthy man. If he is not able to care for her, prostitution is often the only "solution" for such an abandoned wife.

Another option would be that the wives continue to live within the husband's compound, but that he ceases cohabitation with them. This arrangement might also be necessitated by customary law refusing a divorce. Such a situation causes a string of social and emotional problems. The man has one household in which he cohabits, and others which he maintains socially and economically without cohabiting. The continued relationship increases the emotional problems both for himself and his wives. With the great value placed on procreation in African society, these wives will insist on becoming mothers.

${ }^{1}$ See page 141 above. 
It has been noted also in chapter 2 that the customary court may even rule that the husband continues cohabitation with his wives. In such a situation the husband is under great stress caught as he is between the conflicting claims of the church and the customary law.

5. Wives of a polygamist, who have entered into marriage in their heathen state, and who upon accepting Christianity are still not permitted to leave their husbands, because of tribal custom, may upon approval of the local and union committees become baptized members of the church. Should, however, a woman who is a member of the church enter into marriage as a secondary wife, she shall be disfellowshipped and shall not be readmitted to the church unless or until she separates from her polygamous husband. 1

This recommendation allows the wives of a polygamist to be baptized. If the polygamous union is considered adulterous, these women are all living in adultery. How then can they be baptized? If, on the other hand, it is a valid marriage, how can the man in contradiction to the Gospel be commanded to divorce his wives (Matt $19: 9 ; 1$ Cor $7: 12$ ). This ambiguity has become apparent to the Central Ghana Conference (the only field in West Africa having achieved conference status and wholly administered by nationals). As a consequence, they have ceased to baptize the wives of a polygamist.

\section{Recommendations}

It has been pointed out that polygamy as a system clashes with the full ideal of Christian marriage. The polygamous norm then, however acceptable within a given society, cannot be accepted by the Christian church, but it represents one of those adjustments

${ }^{1}$ See page 142 above. 
to culture which must be rejected.

We have now arrived at the point where we may ask Mayer's fourth question: "Who is responsible for changing the norm?" Mayers answers this question as follows:

In a dynamic way, three become responsible for the change of the norm: the Spirit of God, the one whose norm needs changing as impulsed by the Spirit, and the support person. [The missionary--the Church.]

In the biblical revelation, the church is represented as the living body of Christ (Eph 6:23; 1 Cor 12:12). Each Christian, whatever the culture to which he belongs, is a vital part of that body (1 Cor 12:14-27). The unity among the members is expressed forceful1y in 1 Cor 12:25-27, "that there may be no discord in the body, but that the members may have the same care one for another. If one member suffers, all suffer together; if one member is honored, a11 rejoice together." It is in the interaction of the members of the body under the guidance of the Holy Spirit that the Gospel message may shine forth in its purest form.

The church, being called to preserve the unity of the faith and to proclaim the Gospel message with one voice, must be the agent to change the polygamous norm. Therefore, the church must state, as a theological basis for dealing with the polygamous convert, its unwavering committment to the ideal of monogamy. But as it makes an equally strong committment to the ideal of indissolubility, it must deal compassionately with the polygamous convert who, in his situation, is caught between the conflicting claims of these two biblical ideals. Trusting in the doctrine of

${ }^{1}$ Mayers, p. 235. 
justification by faith, the church must emphasize that no human being is outside the reach of God's grace. Therefore, baptism of a genuinely converted polygamist is acceptable on biblical grounds.

The following points may suggest ways of dealing with the polygamous convert within the Seventh-day Adventist Church.

1. It is important that the Seventh-day Adventist church formulate a theological basis for its position in regard to polygamy. Such a formulation would emphasize the basically monogamous and indissoluble character of marriage and also its spiritual meaning.

2. In admitting polygamists to baptism, each case must be carefulty considered. There will, in the converted polygamist's life, be evidence of introspection and confession as a result of a new birth experience. He will be carefully instructed in the biblical ideal of marriage as a monogamous relationship which symbolizes the great transcendental truth of God's covenant relationship to man and the unity and permanency of this relationship. He will understand that although the polygamous situation in which he finds himself is an imperfect and distorted image of this ideal, God's saving grace is sufficient to reach him in whatever circumstances he finds himself. Within his own marriage situation, imperfect though it be, the truily converted polygamist, will, through the sanctifying power of the Holy Spirit, endeavor to pattern his life according to the divine example for the marriage union.

3. The baptized polygamist ought to be admitted to full membership. Baptism places the convert in a saving relationship to Christ and entitles him to membership in God's family--the 
living body of Christ. According to scriptural admonition, he should not be allowed to hold church office. 'This prohibition is not an expression of inferior membership status; it is recognition of the fact that "a Christian leader must exemplify the principles of his profession if he would convince others of the worthiness of his message. A stream flows no higher than its source, and a congregation wi 11 not usually rise higher than its leadership. " 2

4. If the wife (wives) of a converted polygamist desire(s) to leave the husband, separation, according to 1 Cor $7: 15$, should not be resisted. In certain societies, where the marriage pattern is unstable, the marriage relationship between the convert and his spouses poor, and where no social stigma is attached to divorce, the convert might even be counselled to work out, in cooperation with his spouses, a peaceful separation. The wives, however, are not to be dismissed against their own wi11. In the ethical choice between monogamy and divorce, the church should give spiritual counsel and support. But the final choice ought to be made by the convert himself in cooperation with his marriage partners. U1timately, the final responsibility here rests between God and the individual.

5. In dealing with polygamous cases, the church should carefully consider the testimony it renders to society regarding the sacredness of the marriage and family relationship.

6. A change in policy should be carried out in cautious

${ }^{1} 1 \operatorname{Tim} 3: 2$.

${ }^{2}$ SDA Bible Commentary, $7: 297$. 
manner, in order to avoid disharmony. The question of polygamy is an issue which is charged with emotion, not only for the western missionaries, but for the many converts who have thoroughly internalized what the church has for decades taught about polygamy. It is not an easy matter to reverse a policy, which in the past, has caused anguish and suffering for so many. A change in policy, therefore, should be closely connected with an active teaching program in the various fields concerning the spiritual meaning of the marriage relationship and its monogamous and indissoluble character.

7. A change in policy must also be characterized by a unified approach. Whatever opinion one may have about the 1941 policy, the fact remains that this policy has provided a united stand on the matter of polygamy. This is especially important in countries where many members are young in the faith and in spiritual maturity. Indeed, great care must be taken in this regard to avoid confusion, to prevent any ambiguity in attitudes and actions. Therefore, there must be close cooperation between local pastors and field committees regarding baptism of a polygamous convert.

\section{Conclusion}

This paper has been attempted to show that polygamy both juridically and anthropologically constitutes a legal and valid marriage. It has been further shown that it was so considered in biblical times. This recognition confronts the church, in its dealings with the polygamous convert, with the theological dilemma of a choice between divorce and polygamy. Both are seen as 
deviations from God's original plan for marriage which is monogamy. Monogamy exemplifies God's inclusive covenant relationship with man. The tendency in the various missions to prefer divorce is shown as being mainly culturally conditioned. An attempt has been made to resolve the divorce-polygamy dilemma with reference to Paut's concession in 1 Cor 7:10-20.

The historical development of the polygamy issue reveals great diversity of opinion among the men who shaped the various policies of the Seventh-day Adventist Church and engenders the humble realization that a solution to the problem is still an open question. Therefore, an evaluation of the present policy of the church on polygamy is attempted and is followed by suggestions drawn from the principles discussed.

It is somewhat ironical that the increased awareness among various missions in Africa of the theological implications of dismissal--an awareness brought about by greater anthropological and cultural understanding--should come at a time when the African customary marriage institutions show signs of breaking down. This has happened under the impact of urbanization and modernization, with its accompanying social and economical upheavals. The missionary has himself unwittingly been an agent of such destabilizing influences in his ambivalent attitude toward African customary marriage, and his insistence on the dismissal of plural wives. Change in the marriage pattern of a given society is not necessarily for the worse, but it is a great danger that such instability takes place before there are acceptable alternatives. The Western pattern of marriage has little to offer Africa at the present time. Divorce 
is so common among us that many are questioning whether marriage as an institution will survive. Cohabitation without marriage is being readily accepted in Western societies at the present.

Civil marriage according to the Western pattern has long been available in most African countries, but, as noted earlier, very few Africans choose this form of marriage. Not only is this form of marriage foreign to the traditional African, it also interferes with the inheritance pattern of a given society. ${ }^{1}$ In the Ivory Coast, a modern social security law has established that a child's benefits accrue only if its parents have contracted a civil marriage. In spite of the economical advantages this offers a couple with children, few people contract this form of marriage. The effect of the government's attempts have thus been to depreciate customary marriage before people are ready for an aiternative. This has contributed to the current moral and marital instability in the Ivory Coast. More successful has been the attempt to control customary marriage by requiring the official registration of such marriages. So we find among the Yoruba, for instance, that "by the registration of customary marriages adoptive Bye Laws Order 1956, the registration of customary marriages was introduced. " 2 In Ghana, customary marriage stil1 has decisive importance and is recognized by the State as valid marriage.

At such times as these, it is vital that the Christian

${ }^{1}$ In matrilineal societies the inheritance pattern is not from father to son, as in Western society, but from the maternal uncle to child.

2Ekundare, p. 78. 
churches develop a sound theology of marriage and that they uphold existing marriage institutions uncompromisingly and without cultural bias. Most Christian churches are beginning to realize this. In emphasizing the validity of the marriage institutions of different societies, the theological problem of divorce in connection with the polygamous convert becomes evident.

Churches and mission societies working in West Africa are increasingly admitting polygamists to baptism and church-fellowship.

No doubt, polygamy as an institution is on the wane. Already one can observe that polygamy is no longer popular among some educated young men, because they have come to realize the economic burden of having many wives and children. There is now a common saying that "children are not required as an export product." As the standard of living continues to improve, there is every possibility that the number of polygamous marriages will decrease. On the other hand, women are now insisting on monogamous marriages more than ever before. The growing mutual consciousness of famjly responsibility is bound to lead to more monogamous marriages.

The social and economical development in West Africa then is such, that this institution increasingly will be a problem mainly for the rich, supported by the tendency among some African intellectuals to see in it a return to old cultural values and authenticity. But this development will take time, and in the meantime, the problem of polygamy is pressing us closely and has to be dealt with.

Throughout the entire period of the mission of the Christian church in Africa, polygamy has been one of the most persistent obstacles to evangelization. In African communal societies, people often decide for Christ within the extended family group.

$T_{\text {Ekundare, p. } 81 .}$ 
The power and influence of the elders is very great, and these elders are likely to be polygamists. By refusing baptism to these men, the church limits its influence not only over the polygamists themselves but over all the people dependent on them.

Under the influence of urbanization and westernization, paganism is losing prestige while affiliation with Islam and Christianity is associated with education, progress, and prosperity. The disintegration of tribal beliefs and practices as a result of these modern influences provide an unequalled opportunity for evangelization.

The cry of all Africa is for fellowship, especially in the cities where men torn from ancient tribal moorings, suffer from a profound sense of insecurity. . . When tribal beliefs and discipline disintegrate as they are doing under the impact of urbanization, the African who is deeply religious must find an accommodating religion. If the church rejects him because of polygamy, his only resource is Islam, which scripturally has no scruple in this matter.?

It is now forty years since the present church policy on polygamy was formulated. During this period, greater anthropological understanding has been gained through practical experience. The church today has within its ranks more trained theologians than ever before in its history. Would this not be the time for a wise leadership to make an objective appraisal of the church and its dealings with polygamy in an attempt to remove one of the greatest obstacles to church growth on the African continent?

THughes, pp. 205, 207. 
A P P ENDICES 
APPENDIX A

PARTICIPANTS IN THE 1913 MISSIONARY

ROUND TABLE DISCUSSION 


\section{PARTICIPANTS IN THE 1913 MISSIONARY \\ ROUND TABLE DISCUSSION}

J. N. Anderson, missionary in China

T. B. Armitage, missionary in South Africa

J. F. Boettcher, missionary in Europe

C. L. Butterfield, missionary in Korea

L. R. Conradi, worker in Europe and Middle East

R. C. Porter, missionary in South Africa

J. C. Rogers, missionary in British Central Africa

W. A. Spicer, missionary in South Africa

F. H. Westphal, missionary in India and South America

W. C. White, secretary' of the Foreign Mission Board

F. A. Allum, missionary in China

K. F. Benson, missionary in Japan

F. K. De Vinney, missionary in Japan

J. S. James, missionary in India and China 
APPENDIX B

PARTICIPANTS IN THE 1926 MISSIONARY

ROUND TABLE DISCUSSION 


\section{PARTICIPANTS IN THE 1926 MISSIONARY ROUND TABLE DISCUSSION}

W. H. Anderson, mission service in South Africa

W. T. Bartlett, mission service in East Africa

G. A. Ellingworth, mission service in South Africa

G. F. Enoch, mission service in the West Indies and India

E. Kotz, mission service in East Africa

C. H. Parker, mission service in Fiji, Samoa and New Hebridees

W. E. Read, Foreign Missionary Secretary of European Division

W. A. Spicer, also present at the 1913 discussion

A. H. Williams, mission service in India

B. W. Brown, mission service in Mexico

C. C. Cresler, mission service in the Far East

S. E. Jackson, mission service in the Philippines

N. P. Neilsen, mission service in South Brazil

Wm. Steele, mission service in Central and South America

J. W. Westphal, mission service in South America 
APPENDIX C

GENERAL CONFERENCE OF SDA (AFRICAN DIVISION) JANUARY 1926 


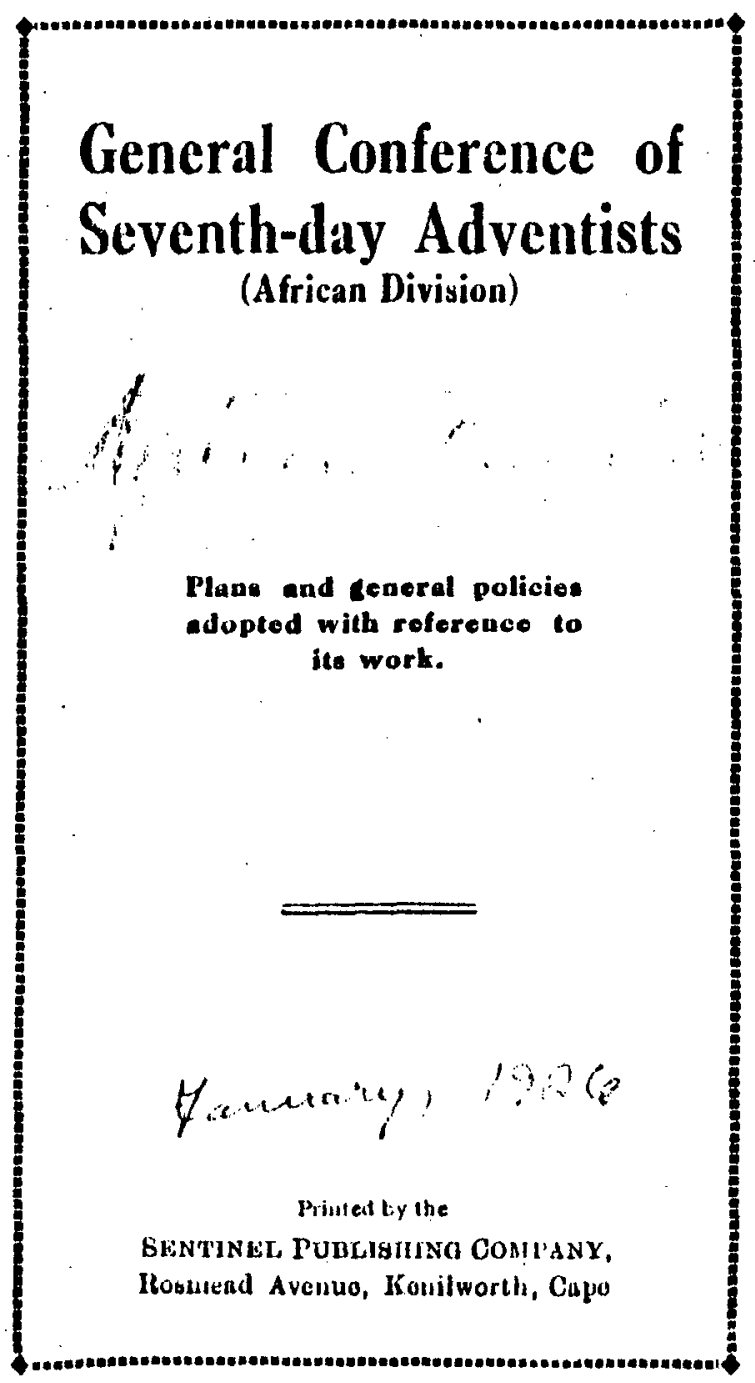


Full members alyo recoive a card indieatingr llwir olanding in llae church, und these cards ute remewed anumally.

Whon tithes and offerings are paid in loy the believers those receiving such futh shall indicate the

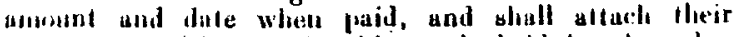
aignatures to life nembership carda lield by these loslievers.

In reporting the totul number of siabluth kecpers, the regpective fields shall include all full church usem. bers as well as 'nembers of the Probationers' and Hearers. Classes.

SAMPII: OI: СAHD:

SEVENTH.DAL ADVEN'LI'T MBGLONG,

This is to certify that

of is 3

\section{MEMBER IN FULL FELLOWBHIP}

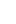

of the

C'incisor.

liecord Na. Date

Valid far ont year.

Misstunaho in challid)

(Record of tithes and offerings is tept on oprosite side of card.)

ROLYGAMY.

Whereas, the Message finds certain natives in Cen. tral and Bouthern Afried living in a stute of polygumy, 
and Iribal enstom in many parto subject a cast-oft wifo to a lifelong shame and disgrace, even to the point of becoming common property, her children also bocoming diugraced therely, it is agreed that nutives liv. ing in the state of polygangy at the tino the gospel light comes to them, who have entered into plural mar. riuge before knowing it to be a custon conlenned by tho Wor.t of God, be accepted as members of the Probationers' Glass, after having opent sufficient time in the Hearers" Claye to giva evidence ol conversion. These persona may bo adaitled to baption and the ordinances of tho cliurch, but can never lold oflice or beconio active in church work, or beconte nembere in full membership, muless or mitil circumstances should change us to leave then with only one companion.

This astion screly contemplates the recognition of a condition which cannot bo changed without resulting in greut injustice to innocent perams, and is not to bis construed as endorsing polyguny in uny way; and unyouc entering into plural marriage relution after receiving a knowlestge of the Truth should be regarded an living in adultery, and dealt with by the church accordingly. A man who hus aposlatised from the Truth, and who during tho stute of his apoutasy, has tuken a plurality of wives, may not be received again unlese he puts away the wives taken during his upostasy. Belore polyganous converts ure baptiecd by anyone, counael should be had with tho superiutendent of the field.

\section{CURPORAL. PUNISHMLNT.}

Corporal punishmest to grown-up boys amil girls on - our mission atations is entirely disapproved.

\section{MisslanahY activities.}

It it considered adviable to conduct the native nissionary activitiog under one dequartuent, and

Whereas the Misaionary Volunteer Department secmcs best adajted to the native felds it is

liecommended that afl the native felds conduct their missionary work under the Missionary Volunteer orgunisution. 
APPENDIX D

SIXTH MEETING, GENERAL CONFERENCE COMMITTEE, MILWAUKEE, WISCONSIN, JUNE 13, 1926 


\title{
AnLitules
}

General Conference

of Serenth-day Adventists

$\$ 5,000$ not be provided in the Dammen Zstate, the North Dakota Conference agrees to make up the balance to the amount of $\$ 5000$

VOTED; That on the conditions specifled above, the treasurer be authorized to advance $\$ 5,000$ to the North Dakota Conference, to be retmoursed from the Dammen Istate within the next two years, and falling this the North Dakota Conference moke up any shortage.

METK OF PRAYER RTADINGS:

The Committee on Topics and Writers for the Week of . Prayer Readings made a report, which was adopted as follors:

We recommend, That the topics and vriters for the Hock of Prayer Readings for 1926 be as follows:

God's Call to His People -- A Call to Advance. Godis Call to His People a A Call to A H Evans. Staggering Impossibilities - Faith's Answer. Building up the Home Base. - A T Cormack. -W C Moffett, G A Roberts. The Response of the Heathen to Christian Standards. Advance in Bacrifice. - - J I Shaw. -. $\mathrm{F}$ H Branson. Cpening Providences. - - F A Stahl, TH Anderson. An Advancing Work in All the Torld. - B E Beddoe. God's Porer as Revealed in the Experiences of His Children. -- L H Christian.

Adjourned.

W A SPICER, Chairman. C K IEYERS, Secretary.

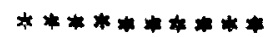 \\ SIXTH WEETING \\ GENERAL CONFERENOE COMLITTEE \\ H1Imaukee, Tis., June 13, 1926, 3:30 P M
}

W A Spicer in the chair. Meeting opened With prayer. BIPNNIAL COUNCIL-EUROFE:

VOTED, That we look with favor on the plan of holding the Biennial Council, in 1928, in Europe. 
$J W$ DAVIS--ATLANTIC UNION:

VOTED, To request the Lake Union and the Chicago Conference to release $J \mathbb{W}$ Davis to connect 1 ith the rork in the Atlantic Union.

I $\mathrm{Y}$ VELENDY_-ATIANTIO UNION:

VOTED, To invite $I \mathbb{H}$ Melendy, roturned from India, to connect with the work in the Atlantic Union.

POLYGAMN AND MARRIAGE RELATIONSHIPS:

VOTED, To adopt the resolutions on polygamy and marriage relationships, formulated as a result of discuselons in the Wissions Round Table during the Conference session, as follows:

Whereas, The practice of polygamy on the part of many races for whom we are laboring is in itself a chal lenge to Christian principles, and constitutes a ground of compromise if permitted in the Christian church; therefore,--

We recommend, 1. That great care be used in the examination of peoples in heathen lands for entrance into the church, and as this examination relates to this practice, we would advise the following:

(a) That in no case should a man living in polygamy be admitted into the fellowish of the church.

(k) That preceding his entrance into the church a sufficient time of probation be given him to test out his sincerity in separating himself from this practice.

Whereas, The marriage ordinance is instituted by God for the good of society and for the protection of the home; therefore,--

We recommend, 2. That where parties are living together as husband and wife, that they be not baptized nor received into church fellowship until they have been le gally married; however,--

Inasmach as we find many partles whose matrimonial alliances becane badly tangled before they accepted the truth, and as the laws of some of our countries are such that it is Imposible for them to become legally married; and as some of these pealre to obey the tiuth phen it comes to them, to be baptized and unite with the church; and in many cases, after careful invest1gation, we can not advise them to separate and thus break up their home and present relationship, for this would only make conditions worse, and knowing that the gospel truth does not come to people to make conditions worse, but better, and that God receives a sinner where he is found and saves him when he repents and turns to $\mathrm{HIm}$ : therefore.- 


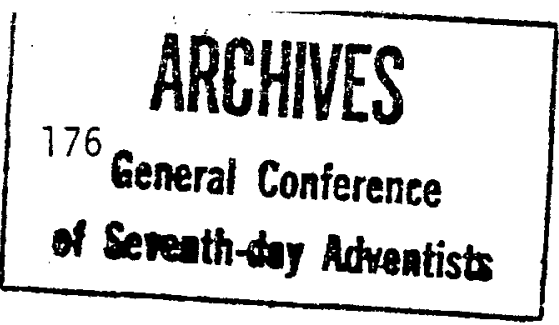

14

Te recommend, 2. That in countries there the laws are such as to make impossible legal narriage of certa1n persons whose matrimonial alliances have become badly tangled on account of these lars; and when such persons have given real evidence that they are truly converted and are in narmony with the truth and aesire to unite with us, all such cases shall be presented to the conference or mission committee of the field in which they reside; and if, after careful investigation, this committee is clear in the case, then the parties may be recommended to church fellowship; with the understanding, however, that if the time ever comes when such persons can be legally married, they do so, and that unt1l so married, they be noteligible to hold any office in the church which requires ordination.

CALP NISETING ASSIGNANTS:

be made:

VOTED, That the following camp meeting assignments ATIAITIC UNION:

New York, Union Springs, Jung 25-July 4, O Montgomery, O K Meyers, F A Stahl, "H Branson.

Southern New England, South Lancaster, July 2-11, 0 Vontgomery, O K Meyers, F A Stahl, Th H Branson.

New England, August 19-29.

CENTRAI UNION:

A $N$ Cormack.

Missouri, June 24-July 4, H I Tll10tt, O Montgomery,

Starr.

Colorado, July 9-17, H T Elliott, A Cormack, G B

Tyoming, July 7 - 11.

Kansas, August 19-29, J Westphal.

\& Nebraska, Auguat 19-29.

COLUIBIA UNION:

TestVirginia, Parkersburg, June 24-July 4, C R Heyers, IA Stahl (two days), $\vec{F}$ O Gilbert, $L$ G lookerjee.

Fest Pennsylvania, July 1-10, C K Heyers, $\mathrm{H}$ Branson, IA StahI, F C Gilbert, I G Lookerjee. 


\section{APPENDIX E}

FOURTH MEETING, FRIEDENSAL, GERMANY,

AUGUST 16, 1926 
BOYCE - CONDOLTICE

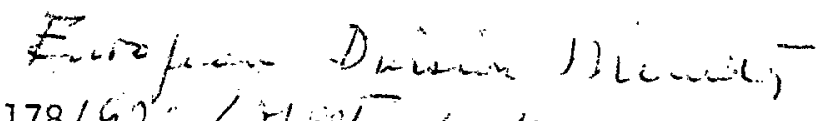

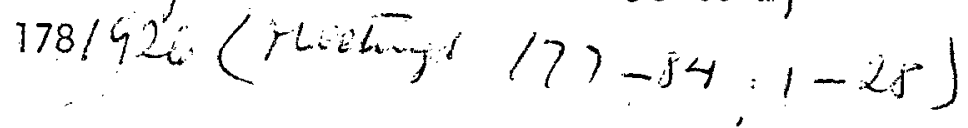

The Chairman made a statement on the sad news receijed at the office of the death of Mrs. H.2. Boyce in inglend resulting from a disease contracted in the Gold Coest nission. It was

VOTID That we express our sincere sympatiny to Brotier Boyce in in bereavement as he is continuing alone in the fold Coast rission.

SOIICZ, SCHIID'I - IRRATSETER

TOTED That we concur with an action taken by the ventra.l ituropean Comititee vith the areement of the fest Cerman Union, viz., 1) inat $i$. Schick of tile Test Cerman Union be transierred to act as presicent of the south Bavarian Joufereice; 2$)$ That H. Scimiat of tile Danstadt school be transferred to tile Test Cerman Union for inizisterial worle.

SCHTBHTHE, H.F. - RHINILAND

VOTHD That re request $\mathrm{H} . \mathrm{F}$. Schuverth to ettend the jeneral meetino of the Pheirisi Conference inust 29 to Soytember 5.

DRIINHAUS - GOLLAND

VOTHD That $P$. Drinhaus ve requested to attend the jeneral neeting of tile Holland Conference, Aujust 24. -29.

L.II. Cirigtiail, Chaimen. V.K. Iaing, Secreiary.

\section{FOURMI IPEDIIITG}

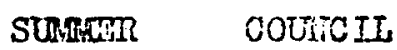

Friedensau, Gemany, iusust 16, 1926 - 9 a.m.

In vietr of tile visit of tive ceneral Conference officers, a Turopean Dirision Council was called at Friedensau, Ausust 16-18, to iro studs to some of tire problems needing attention.

The council was called to order Aufust 16 at 9 a.m., Flder $7 . \dot{\text {. }}$. Sipicer leacing in the opening prayer.

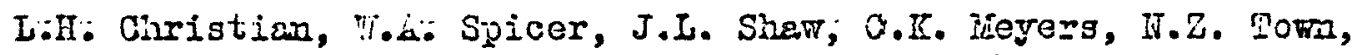
J.T: Boettcier, S.P. Wi Gt, I: Kotz, G.ir: Schubert, Cir. Peciersen, T:T: Isinj, H.F: Scinuberth, J.C. Raft, T.E. Read, P. Drinhaus, C.T. Teals, T.M. Landeen, I.I. Caviness, J.H. Schillin̈, D.N. TaII J. Isanc, P.?. Paulini, h.K. Olson, R.O. Olson, G.T. Norc, R. KüirI ¿. Vollmer, A. Hinck, J. Guel; J. Fintzen, T.H. jísedith,

F. Brennwald, W.T: Bartlett, I.F. Lanfford, Geo. Meouch, T. Cutive o. Schildhauer, B. Ohine, G. Dail, P. Brandt. 
4. That the council proper man from Fridas norning until the eveninf of the second sabbath, it being understood that the General Couference comittee members remain for comittee work over Sunday and rondsy.

5. That large general meetings be planned in various sections of Europe during the following two week-ends, such meetings to be led by general workers and missionaries.

6. Thet the brethren in attendance from the Ceneral Conference and other fields outgide of the Eurojean Division be entertained as suests.

7. That the three fleld secretarles, together with J.H. Schilline: of the East cerman Union, act as a comnittee to vorls out details rejerdins location and 80 forth in Berlin, reporting their findings to the minority comittee. All other details are to be worked out by the minority comittee.

INVITELION TO COUNCIL

TOTWW That the heads of our schools and other leading workers now attending the Biucational Council at Friedensau be invited to the meetinfs of the Division comittee.

COIRIITITESS

1. Mission Candidates.

VOTED That the follotinc act as a combttee to examine missionary Cuilidates: W.T. Read; W.K. Ising, C.K. Heyers, and the union presidents of the flelds from rinich candidates cone, and the mission ouperlintendents of tise fields to which tiney are likely to 80.

2. Mission Finances.

VOTED That the fOIlininis act as a committes to sive study to the financial items of the Missions Ajenda:- V.E. Read, Chr. Pedersen, T.K. Ising, F. Brennivald, T.T. Bartlett.

3. On Various ilission Items.

That the folloving be chosen as a comittee to give siudy to various mission itens:- H.A. Spicer, C.K. Heyers, F.E. Read, W.I. Ising, W.T. Bartlett, L.F: Lanfford, and Geo. Reoush.

POLYGATY - STATEMENT ON

VOTWD That the missions secretary be instructed to pass on to all our missionaries the action taken at the Ceneral Conference session (see Ceneral Conference lifinutes, Sirth lieeting, June 13, 1926, page 13 ) covering the question of polycand, as our jolicy soverning this natter. 
APPENDIX $F$

J. I. ROBISON OBITUARY 
ROBISON, JAMES I.

Born: May 14, 1888, at Humphrey, Nebraska

Died: December 10, 1961, at Sanitarium, California

Review \& Herald, January 25, 1962.

ROBISON--James I. Robison, born May 14, 1888, at Humphrey, Nebr.; died at Sanitarium, Calif., Dec. 10, 1961. He attended San Fernando Academy, then took two years of normal training. He taught church school in Escondido, and in 1910 married Ina Mae Marcus. Together they began a program of denominational work, both in the homeland and in foreign service, lasting nearly half a century. They taught in the Loma Linda Junior Academy for three years, then continued studies at Columbia Union College (Washington Missionary College). Claremont College in Cape Town, South Africa, welcomed their arrival, and four years later this institution was reestablished at Natal and known as Spion Kop. On his furlough in 1921 he attended Pacific Union College, graduating in the spring of 1922. He was chosen as principal of the new La Sierra school, but in 1926 accepted a call to serve as secretary of the Sabbath school and home missionary departments of the Southern African Division. He also edited the Southern African Sentinel. In 1935 he became secretarytreasurer of the Zambezi Union Mission, and a year later was called to be secretary and educational secretary of the Northern European Division. In 1940 the family returned to the States, and he taught 
at Walla Walla College. For eleven years thereafter he was an associate secretary of the General Conference, and in 1956 he became secretary to the president of the General Conference. In 1958 he and his wife moved to St. Helena, California. He continued to serve as a member of the General Conference Committee, a member of the Board of Trustees of the White Estate, and a General Conference representative on the Board of the Loma Linda University. Besides his companion he leaves two daughters, Esther Cowper of Ridgecrest, Calif., and Marjorie Doerschler of Honolulu; four grandchildren; and three sisters, Madge R. Williams of St. Helena, Laura R. Stearns of Turlock, and Stella R. Borg of Sanitarium, Calif. 
APPENDIX G

ACTIONS OF THE AUTUMN COUNCIL, OCTOBER 28 TO

NOVEMBER 3, 1930, OMAHA, NEBRASKA 
"WE are living, we are dwelling, In a grand and a whul time: In an age on ages tellingTo be living is sublime."

$\vec{\infty}$

$4 . \quad 4$ 


\section{Actions of the \\ Autumn Council \\ of the \\ General Conference \\ Committee}

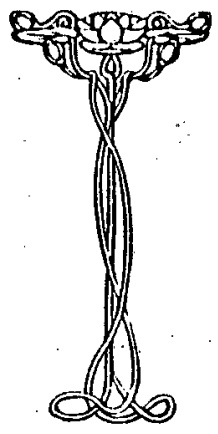

October 28 to November 3, 1930

Omalia, Nebraska

Printel in the U. S. A. 
"He" recommend, 1. That the cinkwoud funior College Memorial be referred to lhe Minority Commitlee of the General (onference and the deducational l)epart. ment for study, alung with the larger question."

Polygamous Marriages in Heathen Lands

The officests in session luefore the: Autumu Conncil made a careliul

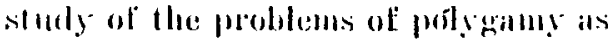

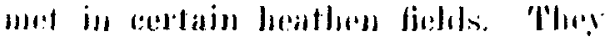
othereal the following resolution, which wass pitsosed:

"W'mintsis, The messare finds people in reatialn bealhen lands living in a stale of polygamy, and where trihal customs sub: ject a cast-oli wife lo lifelong shame and disgrace, even to the point of lecomins common moperty. hes ehildren also bo: coming disgtaced therehy; be: it

"Resolied. That in sta:l sections, per. smimi found living in a state of polygamy al the time the gosnel light comes to them. and who have entered into plumal min. riage betore knowing it to be a clustom condemued by the word of God, may upou recommendation of responsible field com mittees be atdmitted to haphism alla thr. ordinames of the chumh, and may be: recognized as probalionary members. They shall mol. howerer, he almiated tw full membership unlesis of until reireum. stamers chatuge so as to leare them with muly out companion. 
"This action merely comlemplates flot recognition of a contition which in some phaces camot be changed without resulting in great fujustice to innoesut persons. and is not to be comstruted as indorsing polygany in any way. Auy one tentering into a plutal matriage relation alter receiving a knowledge of the truth, should be regarded as living in adultery, and dealt with by the chureh ancomblingly. A man who has apostatized from the Irith. and who during the tine he is in aposilasy, enters into plual marriaka: may not le received agilu into any ehuroh relattionship until he puls away the wives taken during his apostatsy and in every way brings forth fruits moes for mement. ance.

"In countries whore scpallition of lan ilies can be arranged withmul injustin.t. being done to innoccont parties. only one wife should be retained, hut we recognize the right of the man to dorosc the onte 10 be retained."

It is customary for us to say that our last meeting was the best, and many times this is not a mere form of speech. The last should always be the best. It can be truly said that the series of meeting's held at Omaha this autumn were blessed seasons of refreshing from the presence of the Lord. The admonition of our president at the first meeting of the: Antumn Council, to keep the unity 
Which we all felt in mor heants, was fiterally fulfilled. Never before, perhaps, have we faled more serions problems, and never have the leaders attackial those problems with greater aranestness and more furvent faith in God. With the perils of the last days upou us, we must press together in love and unity, put away all hypoctisy and self-sceking, and strive only for the glory of God. We are liviug in a time when the forces of evil are seizing every carthly element; but, thank God, it is also a time when new light and power are deseending "1pon God's people who in liumility of hendt are steking for divine guidance.

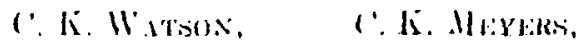

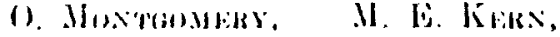

11. II. Bassison. s'cervelaries.

.) L. Melidanx,

Chuirmen. 
GOD has provided divine assistance for all the emergencies to which our human resources are uncqual.--.." Tistimonies ion the Church." Val. Vl. p. +15 .

\section{$\vec{\infty}$}


APPENDIX H

SOUTHERN AFRICAN DIVISION--POLYGAMY 
To guide our workers in dealing with the very complicated problens win ich arise in areas where polygamy is precticed the following policy is adopted:

A man who is a polygamist will not be considered ellgible to become a baptised member of the church unless he dismisses and makes provision for his secondary wives.

wives of a polygamist, who have entered into their marriage in their heathen state, and who upon accepting Christianity are still not free to leave their husband, may become baptised members of the church. Should a woman who is a member of the church enter 1nto narriage as a secondary wife, she shall be disfellowshlpged and shell not be re-admitted to the church unless she separates from her polygamous husband.

$$
\text { (Action 601. 21st Nov, } 39 \text { ) }
$$

Insert policy page 79 before "Light Beer"

$$
\text { (Southem iffican Division) }
$$

\section{"The messege inds people in certain ncn-Christian lands} living in a state of polygany, and where tribsl customs subject a castoff wife to life-long shame and disgrace, even to the point of becoming common property, her children also beconing dispraced thereby.

In such sections, persons found living in a state of polygamy at the time the sospel light corses to them, and who have entered into plural marriage before knowing it to be a custom condemned by the viord of cod, may, upon recomendetion of responsible field comittees, be admitted to baptism and other ordinances of the church, but may not vote or be elected to office. Trey shall not be ecritted to full membership unless or until circumstances shall so change as to leave them only one companion.

This action contemilates merely the recognition of a condition wich in some places cennot be changed without causing great injustice to innocent persons, and is not to be construed as endorsing polysemy in any wey. Any one entering into a nlural marriage relation after receiving a knowledge of the truth should be regarded as living in auditery, and dealt with by the church accoringly. i man who has apostatised from the truth, and who during the time he is in apostasy enters into piural marriage, may not be recefved ggain into any church relationship until he puts away the plural wives taken during his apostasy, and in every way brings torth fruits meet for repentance.

Where separation of farilies can be arronged, without injustice being done to innocent parties only one ufe should be reteined. (Eouthem Asia Division, 1937) 
Folygamy, Continued.

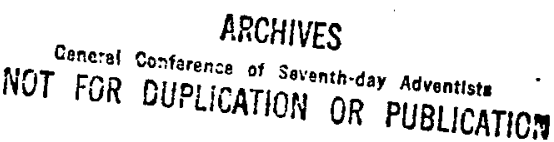

"In view of the alarriting increase in the number of divorces in tre world, and of the Erowine disregard for the secred vows of marriace, rany seemingly considering marriage only a business arrangement to be entered into for personal advantages; and furthermore, in view of the constant aanger of our people being drewn ayay by the spirit of the times and lookins with complaisance upon that which the vord of God condemns, it seers necessary to reiterate and emphasise the fact that we greatly deplore the evil of divorce, and place emphatic disaprroval upon any legal action for the separetion of those once merried, on any ground other then that given in liatthew $5: 32$.

(China Division, 1932)

"WFERELS, The message finds people in certain heathen lanas living in a state of polygamy, and where tribal customs subject a cast-off wile to lifelong share and disgrace, even to the point of becoming comion property, her children also beconin aiseraced thereby; be it

"WiSOLVED, That in such sections, persons found living in a state of polygamy at the time the gospel li ht cores to them, and wio have entered into plural marriage before knowing it to be a custom condemned by the word of God, may upon recormendation of responsible field committees be admitted to beptism and the oriinances of the church, and ray be recognised as probationary nembers. They shall not, however, be admitted to full membership unless or until circumstances change so as to leave tinem with only one companion.

"This action merely contemplates the recognition of a condition which in some places cannot be changed without resulting in great injustice to innocent persons, andis not to be construed as indorsins polygamy in any way. Any one entering into a plurel marriage relation after receivins a knowledge of the truth, should be regardad as living in acultery, and dealt with by the church accordingly. A man who has apostatised from the truth, and who during the time he is in apostasy, enters into plural marriage, mey not be received agein into any church relationship until he puts away the wives taken during his apostasy and in every way brings forth fruits meet for repentance.

"In countries where secaration oi families can be arranged without injustice beins done to innocent parties, only one wife should be retained, but we recognise the right of tive ren to choose the one to be retainea."

(fiutumn Council of the General vonference,1830) 


\section{APPENDIX I}

WORKING POLICY, CENTRAL EUROPEAN DIVISION, FEBRUARY $3-11,1939$, CAIRO, EGYPT 
Those constituting both these classes must be under definite and constatt Bible instruction during the entire period. The two classes should always be conducted separately. It is advised that di,e Bap. tismal Manual prepared by the General Conference be used in conducting these classes.

When members are transferred from the inquirers" class to the adherents' class, they shall receive an adherenty' class card. A complete record of these inquiress' and asherents' cards is to be kept at the respective churches or mission stations.

Full members should also receive a card indicating their standing in the church, and these cards should be renewed annually.

(Sample Card)

SEVENTH-DAY ADVENTIST MISSION

This is to certify that of is $a$

Member in the Inquirers' Class

Member in the Allherents' Class

Membor in Full Fellowship

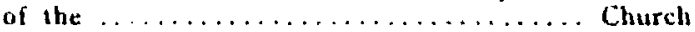

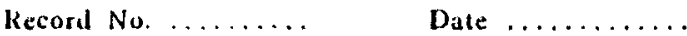

Local Worker or Elder

Valid for one year.

Missionary in Charge

(It is suggested that a separate card in a distinclive color be used for each class. The commillees concerned should provide these cards for use in their respective territories.) 


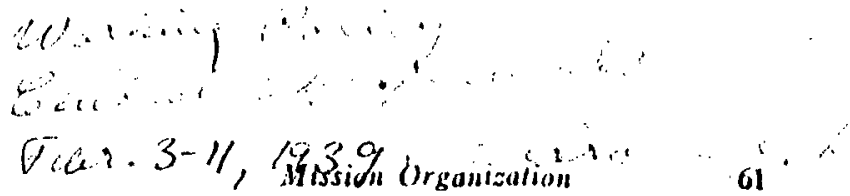

When tithes and offerings are paid in liy the believers, those recciving such fumis shall indicate on the hack of the card the amumint paid and the date, and they should athach their signature to the entry thus made on the cliss card held by the believers.

In reporting the cotal sumber of Sablablikepers, the respective fields shall include all full church inembers as well as members of the adherents class.

\section{POLYGaMY}

The message finds people in certain non-Christian lands who are living in a slite of polygany. In these lands trilsal customs subject a cast-oif wife to lifelong shame and disgrace, even to the point of hecoming common property, and her childien thereliy also become disgraced.

In such sections, persons found living in a siate of polygamy at the time the gospel light comes to then, and who have entered into plural marriage before knowing such a custous to be condemued hy the word of God, may. upon recommendation of responsible fielil cummittes, the admited to baptism and to ather ardinances of the clurch, liut may not vote or be elected to office. They shall not be admitted to full nembership unless or until circum. stances shall so change as to leave then only one companion.

This action conlemplates merely the recognition of a condition which in some places cannot be changed without causing great injustice to innocent persons, and is not to be construed as endorsing polygamy in any way. Anyone chtering into a plural marriage relation after receiving a knowledge of the truth should be regarded as living in adultery, and dealt will by the church accordingly. $A$ man who has apostatized from the truth, and who during the time he is in apostasy enters into plural marriage, may not be received again into any church relation- 
APPENDIX $\mathrm{J}$

POLYGAMY, STATEMENT OF THE GENERAL CONFERENCE

FROM THE NORTHERN EUROPEAN DIVISION. 


\section{Y I I G A YY \\ Statoment to the Ganeral Coniarence Committee \\ Prol. tha Northarn Julopan Division.}

ARCHIVES

NOT FOR DUPLICATION Senth-day Adventists

We have been asked by the Kenya Union to present to the General

Conference their earnest protest against the adoption of a policy in

Tanganyika territory which allows of the bcptisine oi polycanists.

In 1926 the Genoril Conference in session at i.ilwaukea, voted tine following resolution:

"ivilias the practica of polycamy on the gart of nany races for whom we are labouring is in itself a challence to Christian principles, and constitutes a round of comprouise if permitted in the Christian church; therefore,

We Recommend (1) That creat care be used in the examination of peoples in heatien lanls for entrance into the church, and as this examination relates to this practice, mo rili advice the POllovine:

(a) Lint in no case should a man living in polysry be admitted into the feilomship of the cluron.

(b) That preceding his entrance into the church, a sufficient time of probation bo siven him to test out his sincerity in sepuratine himself from this practice."

The language of this resolution sems careful to be only advisory in its intent, but the aivice is explicit thet "in no case" should a polyounist be admitted into the church. The preimble declares that polyzamy is "in itself a challenge to Christian principles", and if permitted in the christian church it mould be"a fround of compromise". The expression "ground of compromise" may be read in more than one way. As the resclution was understood at the General Conference, the exprossion "ground of compromise" was intended to be unierstood as a "istal comrromise". It was the conviction of the majority who voted this resolution that the entrance of polyeamits would constitute a deady compromise and a disloyalty to Christian principles.

It is a painful surprise to learn that notwithstanding these utterances on the part of the full Genercl Conference in 1926, the Autum Council of the General Conference in 1930 sound it possible to make a compromise with polygamy and to permit its entrance into the jeventh-day Adventiat church. The action roads as follow, so far as the vital portion of it is concerned:

mersons found livins; in a state of polycamy at the tine the gospel light coms to them, and who have entered into plural merriage before knowing it to be a custom condemed by the jord of God, may upon recommendation of responsible full conmitteos, bo alinitted to baptism and 
the ordinances of the church, and may be recognised as probationary members. They shall not, hovever, be admittad to full membership unless or until circumstances change so as to leave tiem with only one conpanion."

In 1926, at the Genersi Conierence, there was an argument on polygamy presented by tre Arrican Division, askins for some degree of recognition to be given to polycamists round so by the messace, and in their working policy that Division had already incorporated the following:

Goneral Conference of Seventh-cay Adventiats

"It is aereed that natives living in the states of polygamy at the time the cospel licht comes to them, who have entered into plural marriage before knowing it to be a custom condemned by the iord of God, be accepted as members of the probationers class, aiter having spent sufflcient time in the Hearers class to zive evidence of conversion. These persons nay not be admitted to rull nembeiship or baptism unless or until circunstances should change so as to leave them with only one companion." - Eage 57 of the African Division Vorking Policy.

Later the African Division, now known as the Southern African Division, in 1939 withdrew from this parial recognition of polyeamy and adopted the following as part of their working policy:

"To zuide our rorkers in dealing with the very complicated problems which arise in areas where polygemy is practiced, the follouring policy is adopted:

"A man who is a polycamist will not be considered eligible to become a baptised member of the church unless he dismisses and makes provision for his secondary wives."

According to this, the Southern african Division stands at the present time squarely on the policy enunciated by the General Conference in 1926. However, in the Southern Asia Division, in 1937 the revised policy voted by the iutumn council in 1930 was adopted, admitting polygamists to baptism, but not to rota or to hold office. Now the Central Eurcpean Division, jection II, so fur as its African mission in Taneanyika territory is concerned, has tollowed the same policy.

Thus the position seens to be that the General Conference in full session stands on ono side as distinctly oprosed to the baptism of polyganists wile an sutumn Council, followed by the Jouthorn Asia Jivision, and the Central Bropean Divizion stands on the other in allowirg the baptism of polyoumists. Thane is urgent need that the General Conference in fuil session should jive earnest study to tis aivision on a mattei of vital importance which the Ceneral Conference itself has declared to be a challence to Christian principles and "a round of comijomise" if permitted.

Our Kenya Union being a next door neichbour to Pan anyika territory, is sericusly affected by whatever new policy may be introduced into its neighbour mission ilid. From the beginnine of our work in the Kenya Union, going back to 1907, the leadersinip has insisted on the absolute incompatibility between polycamy und Seventh-day Adventist teaching. Both Uganda and Tanganyika teritory, while the latter field was in the Jast African Union, have been broukht up in the same principles. The three fields are in close contact by means of easy travel, and the common use of the Swahilf language, and any compromise made in one of the three 
Both in Uganda and in Kenya considerable work has been done by Turious large missionary societies, and these societies have stood strongly acainst any recocnition of polygamy, yet the evil of plural marriages has steadily crept back, and done a great deal to destroy the missionary work that was accomplished in the past. Folygamy is still the Ereatest enemy and the ereatest danser of the native churches in those regions. If Seventh-day Adventists come to be known in these territories as divided, or unsound in their stand acainst polycemy, that would be the ereatest disaster to our cause and the ereatest triumph our enemies could possibly cnjoy. They would accuse us of a fatal compromise with the common foe of Christianity.

At the present time our mission has won a reputation in East Africa for sound Bible teachines; pven our enemies allow that Adventists are the strongest of all the missions on the Bible. Rival societies have sometimes acknowledges that they are in our debt because of our strong stand on the Scriptures. They noint their own members to us as an example of Christian consistency. One of the strongest societies has, contrary to its usual practice, agreed to baptise by immersion if its member's desire. Others have taken up the principle of tithine, and one society to our knowledee, even introduced the washing of feet - the ordinanco of humility. If we give way on the point of polygamy we should not only weaken the hand of the other societies who vage continual war on polygamy; we should also terribly weaken the hands of our own worker's in Kenya and Uganda in fichting the ever present danger that threatens our ovn membership because of the strong temptation to return to the practice of polygamy. Among so many erceilent and encouraging features over which we rejoice in our native Kenya churches, the saddest feature of our experience is the continual inroad made by polygamy among our nembers and even our workers.

Nothing would be more discouraging to our home churches and tend more certainly to ary up the flow of mission gists than the idea that we vere not standing uncompromisingly against polygamy.

In Jast Africa there are soveral Judaizine novements, one of them with a membership of 50,000 , that have broken away from the older missions on tro leading points, one is the keeping of the sabbath, and the other is polygamy. These movernents oiten seek union rith us. If we let the standard down we could cuickly add thousands to our baptisms, but that would be the end of our caryer as a Christian missionary Porce in East Africa.

The Autimn Council also surgests that polycamists received into our churchss shoula only be recognised as probationary members, but at the same time tiey shoula be admitted to baptism ind tive orainances. The resolution of the Southern isia Division seems to interpret this as meaning that they may be acritted to baptism and the ordinances out not be permitted to vito or hold office

luissionaries op experience can best recilse hivit lind of church this molld produce. In new ijelis it wuld be likely to mean that the majority of the nembers would be polyzaists. It is not to be imacined that these vould long be content with inferior relationship to other members. Our experiance in rigeria indicatos what ni wht be the rasult. 
There we have lone been etublished, ani have hat tha sad experience of seeine many of the older membels return to polygany, or else apostetize fiom monosamy to polycamy. They still come to worsip nith ds and claim thet in all other respects beileva as we do. The Arrican conscience is not always wide-avake on tho subject of tile sin of polycamy. The areuments drawn from the old Testament seem to them to be cuite valid acrainst the teachings of the liew. Polycumists often, by renson of their polygamy, secure wealth and stancing in the community. They are able to exercise hospltality freely and the nembers of the church enjoy acceptine the hospitality. In thege priendiy gatherings the policies of the church are discussed, and the combers are strongly influenced by the reasoning of the polyeamists und sometimes accept their suegestions as to how their vote should be used when questions arise. To our deep charrin We find that ting polycumists who are su:posed to be outside, are still ezertize a powerful influence over our native members. In some cases they are iiberal in their eifts of money and in supporting schools, and the native nembers sometimes wonder whether they could carry their local financial burdens withicut the help of the senerous polyigamists. How much stronger micht these dancerous influence become if we actually received polycamists into church membership and gave them all the privileges except those of voting and holdine office! At the innual meetings these polygamists turn up in strength, and give lar;er offerings than the others. It has happenoi that the chief who comes to the gathering and sits in state before the vletform is linself a one time member who has relapsed into polysamy. Apart from this, the chief mentioned seems to be aimost a nodel in Christian conduct, in habitual prayer, and in his desire to see the mission doine a stronf work.

In the study of this problem le must not merely jympathise with the unfortunate position in which the polycamist finds himself when the truth is presented to him. is a metter of fact our missionsries cannot but feel the deepost symeathy with tho intricate involverent in mich the polycamist has bound himseli. ie may recosnise that as a polygamist he seems hopelessly tied in the fetters of the system and anparently oxcluded from the Kingdom of heaven. His state of helpless bondage moves our sympathies strongly, but we must realise that this insoluble oroblem, which only strong faith in God can solve for the polygamist, is the triumph of Satan's schemes. Polygamy is the most successful product of Satanic cunning. It was aesigned so as to hold men in hopeless subjection to the heatherism of wich it is the chief fruit. It is from tinis angle that we must view polyeamy, and never compromise with it, but proclaim it for what it is, the utter ioe of the rosrel, to be fought and conquered at all costs. To make compromise with the polygamist so as to eive him access to the church, is to wive the ifrican church over to the workine of Stitin.

Polygamy mins the divine institution of the hone, and makes a Christian farily an abisulute impossibility. It fastens the romen in defrading bondaee so that they sink to the level of cattle. The effect on the polygamist hirself is to keen his sexual instincts in a state of lifelong exitement and so to war a kinst all the spiritual forces that heaven irould bring to bor upon nim. No home is cossible for the polymamist, only one unhapy whirl oi jealously, avarice, hatred and revenge, hich destroy love in the heart of husband ani rives, and althoueh as a rule it dovilops strone $i$ iroction betinen the ronan and ber ow off-spring, this alpotion hi its avil aide in a rasing 
joalousy againet the chilizen of tho rivals.

The Cristian church nust stand or fall as it conzuers, or is compelled to yield to tho powertul arpeals of nolyamy. If we eive way here vo fail all alone the line.

ARCHIVES

Goneral Conference of Seventh-dey Adrentiste. NOT FOR DUPLICATION OR PUBLICATIOA 
APPENDIX K

HOME AND FOREIGN OFFICERS' MEETING, MAY 20, 1941 ,

SAN FRANCISCO, CALIFORNIA 
tho oburob enter into warriego as a secondary wife, she shall be diafellowhippod and shall not be readnittod to the ohuroh unless or unt1l aho soparatos from hor polyganous husband.

"6. It 1s understood that tho abore polloy supereeded all provlous polleloa on polygary."

\section{STANDSRDS TOR RAPTIEY U}

The subcoittoo presentod a report uhich in 1ts anonded form we adopted as follcws, to bo euluelted for coneidoration by tho Brangolistio Counoll and eubsequantly by the Ceneral Conforonoe in sessions

THS RECOGNIEB Thet cortain escential churoh otandarda must bo ostabliched and ralntalnod, woh bolng oicarly understood and coooptod by all candidates for baptica and messoorship within the romant ohuroh.

"Throughout the yoars these etandards hare been olearly onunolated by the leadershlp and ooted upon teneral Conferonos sos stons and other representative Eathorings of the workers and churoh momioers.

Wo regret that individual rorkers and organizationo havo at timos attomptod to outabilain thoir own etancards. frequentiy folng muoh boyond tho mind and expression of tho general body and bringing unneoveang embarrassmant and maunderstanding to now converts and folzor bellevors.

"Ho would diroot the attention of our roricers and orgsnlsetlons to the prinolploa clearly leld down in our Cheroh lanual ulth roepoot to standards and praotices, and roquest that suoh be folloms without any attent to introduce any viowe or atariarda not adopted by tho goneral body."

\section{UNTFORU FURLOUGH APPLICATIOH BLATK: $D$}

Aprsed, That the quostion of a undform Purlough Lppliontion Blank bo roferred to the Gonoral Conferenoo seoretarles and tho Seorotaries of dividione, with power to aot.

\section{STTUATION RECABDIEG GERRAN TORKERS}

IH THE OBTEET?

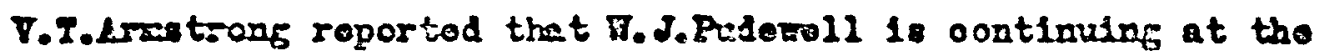
atesion oapound in Sooul, shilo ifro. Eejorell and the chileren aro In Germany and canblo to rotura at the prosent tive. Brothor Armatrons explainod that it was not the deslro of Erother Pudowoll to zotarn

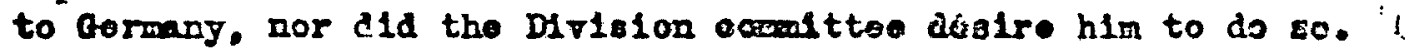
In tho case of G. DLotrlch. V.I. Anetreas roported that for norarel monthe ho ias not boen ablo to vork owng to polios interrextion. Eo is tranted as though bo wore on inorican miesionary. Tho Ditialon comittoo haro no othir plece to whioh ho oould be transforred. Tho mision leadors talkod tho nattor orer with Brothor Diotrioh, and Inssmuoh as thore ma no plaoo hare ho could profitably iabor in the ouse at the prosent tima, ho doeirod to take up colf-aupportirg wark, hoping that at cose timo in tho future ho oould rocirn to nis Bicn warl. The dapenese brotirion had unandmoucly ladicatol thet it fould not bo In tho lntoresto of tho work in sapan for Brother pietrich to continue In misolon work at the prosort timo. B.F.Browor roported that 
APPENDIX L

PROCEEDINGS OF THE GENERAL CONFERENCE SIXTH MEETING JUNE 5,1941 


\section{Proceedings of the General Conference}

\section{Sixfeenth Meeting}

June 6, 1941, 3:30 r. 3.

Cuatrmax: L. II. Christian.

Orrixisu Soxf: "My llope Is Bullt on Nothing Less," No. 581 In "The Church Hymnal."

Prayer by J. F. Plper, preatdent of the Central Uuion Conference.

Srealal. Ali'sle: "I Shall know HIm" was sung by Mrs. Vera WoodmanBristow.

L. II. Cunintian: The plan of the cession this afternoou is that we devote half an hour to rarlous Items of buslness and then at lour-ten o'clock Ifisten to a report of the College of Medical Erangelists, which will be given by Dr. P. T. Magan. A series of $X$ recommendations on polygamy has come to us from the General Conferenre officers. We shall ask the secretary to read It.

A. W. Corsack: Brother Chairman and delegates, these recommendations read as follows:

\section{Polygamy}

Wilzreas. It is clearly God's plan that man should live in a state of monogamy, that is, that a man should have only one living wife: and.

Wueness, Any contrarention of this plan results in confusion and the lowering of the moral standards that should govern human society, and espectally the church of Christ: and.

WuElks.s. The practice of poiygamy on the part of many non-Christian peoples for whom we are laboring is in itself a challenge to Christian princlples, and constitutes a ground of compromise if permitted in the Chrislian church;

We rcommend, 1. That a man tound living in a state of polygamy when the guspel reaches him. shall upon conversion be required to change his status by putting away all his wires enre one. before he shall be considered elifible for baptism and church membership.

2. That men thus putting away their wiven shall be expected to make proper provistou for their future support, and that of their chilliren. just as far as it lo within their nower to do so.

Wurktis. The message finds people In certaiu countries living in a stute of polygany. Where tribal customs subject a wife. who has been sut away to Iffelong shame and disgrace, even to the polut of becoming common property, her children also becoming diskraced thereby:

We rioumment. 3. That in all such cares the church co-operite with the former hushand in making such pro. vislou for these wive'y and chlldren as will provlde for their enre and profect them from disgrace and undue suffer. ing.

4. That we recognize the right of " wite who has been but awily by a polygunious linslumd to marry nenlu.

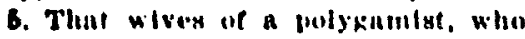
have entereal into marrtake in thotr

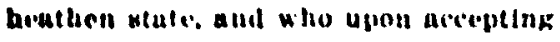

Christunlty ure stlll not normitted to leuve thelr husbands. because of irthal custom, nay upon approval of the locen and union conimitters berome haptlyed nembers of the churih. Ilowever, should a woman who is a menber of the church enter into marriage na a serondary wife, she shall he disfillowshiped and shall not be readmitted to the church unless or untll she scparates from her polygarnous hushand.

6. That it is understond that the above pollcy supersedies all previous pollcles on polygamy.

L. H. Cirhintias: These reconmendations have been worked out by a large committee with very much rare. We will ask O. Montgumery, who was head of that committee, to make some explanatory remarks concerning them.

O. Mostiomriy: In 1926 a recommendation was adopted on the subject of polygamy, establishing a policy.

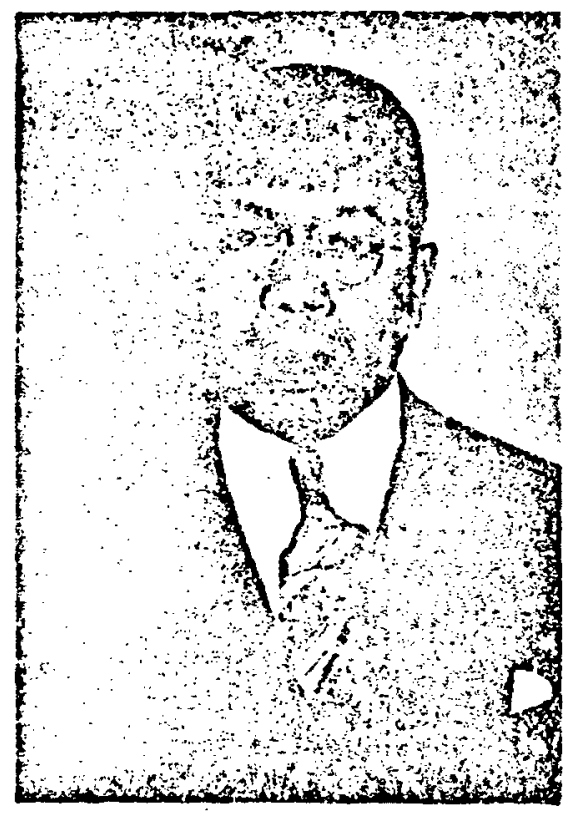

1. F. Leters. Sewly Flinterl Sncretary of uip Segro Department

Then in 1930 another policy was adopted. It was recognized that a man living in polygamy might be buptized and enjoy the privileges of the rhureh. but that he should he recognized as a probatlonary nember, not having the right to hold once or vote.

You will notlce at once that this was something of a conpromise. Sune flelis adopted the 1926 policy, and then, following the 1930 Autumn council, other fields adopted the 1931 policy. Thus we had two dinerent polldi's in eftere In our world theld. and where the different misalen flelds borlared on one wnother or lay close togellor, these two standards brought ronluslon. embarrasiment, and perplexity. It was, therefore, felt by the oincers and representatlves of the misston nolds who met with them ling there alionile be a world-wide unlted standuril on this perplexing quistion;

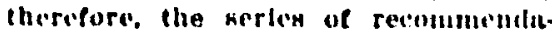
llons that are beforo you was drawn up. Thene ure ntrons: and clent and will nako proviston for those wiven polycumous husbund.

I mily may that all the representa. tlves of the mission flelds who were prement in our council wero unlted in the adpotion of this series of recom. inendations us being the strongest ind clcarent. and the safest pollcy to tol. low. These recommendatlons rrally take us back to the 1926 princlple, stated in a broader and fuller way. I thluk, Nrother Chairman, that this makes the matter clear and glves to the deleration an understanding of the renson for introducing these recommendations to take the place of the 1926 Geueral Conference action and the 1930 Autumn Council action.

L. H. Cunistrix: Thank you, Brother Montgomery. We have heard this statement read, and we have heard the explanation given regarding why it was necessary to draw it up. The rote will now be taken.

The recommendation was duly voted.

A. W. Cormack: We come now to a turther report from the Plans Committee. This concerns transferring the Home Commission to the Educational Department. I might say. Brother Chairman, that the series I am about to real is that to wich reference was made in the Nominativg Committee's report this morning. It was thought that we had already acted upon it. It is headed, "Transfer. of Home Commission to the Educatlonal Department," and reads as fol. lows:

\section{Transfer of Home Commission to Educational Department}

Winsmas, It is clear trom our perception of the edlucational process that education begins with the beginning of llfe, that the home is the foundation school and parents are the first teàchers, and therefore that our educational system should include this elementary work; and,

WiEtras, We are instructed in the writings of the Spirit of prophecy in recognize the home as "the freatest of all educational agencles," and to pro. ville for the training of parents both actual and potential; and,

Wirgras, The Home commission has pioneered in parent education and home teaching. untll it has become evldent that this work shuuld be madu in integral part of our educational system: therefore,

We recommend, 1. That with effert from January 1, 1942, the Ilome Commission be merged in the Department of Elucution, and that home education be recognized as a diviston of the educullonal work, co-ordluato with the dementary, secondary. and collego divistons.

2. That in vtew of this arlded re aponstbllley and rork, consideration be siven at the time of the 1941 Autumn Council to tho appolutment of all nsalatunt secretary to be added to the Depurtmont of biducation of tho (Beneral Conference, to asalyt in roster. tils and promotling in every upuroved nutnner thin work of educatlus tor tho

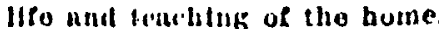

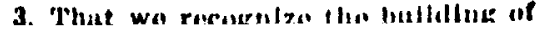


APPENDIX M

COMMITTEE ON POLYGAMY, 1941 
COMMITTEE ON POLYGAMY, 1941

L. H. Christian, General Vice-President of the General Conference

J. F. Wright, President, South African Division

W. E. Read, President, Northern European Division

N. C. Wilson, President, Southern Asia Division

E. D. Dick, Secretary, General Conference

A. V. Cormack, Associate Secretary of the General Conference

W. H. Branson, President, Central European Division

Branson and Wilson were both leading the work in Divisions which followed the 1930 policy. Read was the President of the Division who objected to the introduction of a 'lenient policy' in a neighboring mission territory. L. H. Christian was a former leader of the same Division. A. W. Cormack was a former leader of the Southern Asia Division. E. D. Dick had experience as field secretary of the African Division. J. F. Wright had worked in South Africa since 1925. 
B I B.L I O GRAPHY 


\section{BIBLIOGRAPHY}

Aceves, Joseph B. and King, Gill H. Cultural Anthropology. Morriston: General Leaning Press, 1978.

Agyemang, Fred. We Presbyterians. Accra: Select Publications and Promotions, 1978.

All-African Seminar on the Christian Home and Family Life. Lauzanne: Imprimerie La Concorde, 1962.

Ardener, Edwin. Divorce and Fertility. London: Oxford University Press, 1962.

Baëta, C. G., ed. Christianity in Tropical Africa. London: Oxford University Press, 1968.

Barnes, Albert. Notes on the New Testament. Grand Rapids: Baker Book House, 1953.

Barnes, J. A. Marriage in a Changing Society. Manchester: University Press, 1957.

Barth., Karl. On Marriage. Philadelphia: Fortress Press, 1968.

Berglund, Axe]-Ivar. "The Biblical Concept of Man/Woman Relationship." Cited in Verryn, T. D., ed. Church and Marriage in Modern Africa. Johannesburg: Zenith Printers, 1975.

Bohannan, Laura. "Dahomean Marriage." Cited in Bohannan, Paul and Middleton, John, ed. Marriage, Family and Residence. New York: The National History Press, 1968.

Bohannan, Paul. Social Anthropology. New York: Holt, Rinehart and Winston, 1963.

Bohannan, Paul and Middleton, John. Marriage, Family and Residence. New York: The National History Press, 1968.

Bonhoeffer, Dietrich. The Cost of Discipleship. New York: Macmilian Co., 1963.

Bowker, J. W. "The Correlation of Theological and Empirical Meaning." In Marriage, Divorce and the Church. London: S.P.C.K., 1972 . 
Caillet, Emile. Christianity in Tropical Africa. New York: Abingdon-Cokesbury Press, 1953.

Caincross, John. After Polygamy Was Made Sin. London: Rutledge and Kegan PauT, 1974.

Colenso, J. W. Three Weeks in Natal. A Journal of a First Tour of Visitation Among the Colonists and Zulu Kaffers of Natal. Cambridge: Macmillan and Co., 1865.

Dawson, Christopher. The Historic Reality of the Christian Culture. London: Rutledge and Kegan PauT, 1960.

Derrick, Christopher. Light and Revelation and Non-Christians. Terence J. Cooke, 1965.

Desai, Ram. Christianity in Africa as Seen by Africans. Denver: Alan Swallow, 1962.

De Vaux, Roland. Ancient Israel. Social Institutions. New York: McGraw HilT Book Co., 1961.

Dominian, J. Christian Marriage. London: Darton-Longman-Todd, 1964.

Dorjahn, V. R. "The Factor of Polygyny in African Demography." In Continuity and Change in African Culture. Chicago: University of Chicago Press, 1959.

Dwane, S. "Polygamy." In T. D. Verryn, ed. Church and Marriage in Modern Africa. Johannesburg: Zenith Printers, 1975.

Ekundare, R. 0. Marriage and Divorce Under Yoruba Customary Law. Ile Ife: University of Ife Press, 1969.

Faucher, François. Acculturer l'Evangile: Mission prophétique de l'Eglise. Montreal: Fides, 1973.

Fortes, Meyer. Kinship and the Social Order. London: Routledge and Kegan PauT, 1969.

Fosdick, Harry Emerson. A Guide to Understanding the Bible. New York: Harper and Brothers, 1938.

Fox, Robin. Kinship and Marriage. Baltimore: Penguin Books, 1967.

Gluckman, M. "Kinship and Marriage among the Lozi of Northern Rhodesia and the Zulu of Natal. In Radcliff-Brown, A. R. and Forde, Dary 11, ed. African Systems of Kinship and Marriage. London: 0sford University Press, 1964.

Goody, Esther N. Contexts of Kinship. Cambridge: Cambridge University Press, 1973. 
Grunlan, Stephen A. and Mayers, Marvin K. Cultural Anthropology. Grand Rapids: Zondervan Publishing House, 1979.

Guerry, Vincent. La Vie quotidienne dans un village Baoule. Abidjan: Inades, 1970.

Ha11, R. H. "Marriage Law in Ghanaian Churches." In Hastings, Adrian. Christian Marriage in Africa. London: William Clowes and Sons, Ltd., 1973.

Hastings, Adrian. Christian Marriage in Africa. London: William Clowes and Sons, Ltd., 1973.

Hastings, James. Dictionary of the Bible. Vol. 3. New York: Charles Scribner's Sons, 1900.

Herkovits, Merville J. Acculturation. Gloucester: Peter Smith, 1958.

- Cultural Relativism. New York: Random House, 1971.

- Church Dynamics. New York: Alfred Knapps, 1964.

Hi17man, Eugene. Polygamy Reconsidered. New York: Orbis Books, 1975.

Keesing, F. M. Cultural Anthropology: The Science of Custom. New York: Holt, Rinehart, Williams, 1966.

Kirwin, Michael C. The Church Prohibition of the African Leviratic Custom. Ann Arbor: Xerox University Microfilms, 1974.

K1 ineberg, 0. Race Differences. New York: Harper and Brothers, 1935.

Lane, William L. The Gospel According to Mark. Grand Rapids: William B. Eerdmans, 1974.

Luzbetak, Louis J. The Church and Culture. Techy: Divine Word Publications, 1970 .

McGavran, Donald. The Clash Between Christianity and Cultures. Washington, D.C.: Canon Press, 1974.

Mair, Lucy. African Marriage and Social Change. London: Frank Cass and Co., 1969.

Malinowski, Bronislaw. Sex, Culture and Myth. New York: Harcourt, Brace \& World, Inc., 1962.

Marie-André. The House Stands Firm. Milwaukee: The Bruce Publishing Company, 1962 . 
Mau, David R. Whom God Hath Joined. Philadelphia: The Westminster Press, 1973.

Mayers, Marvin K. Christianity Confronts Culture. Grand Rapids: Zondervan Publishing House, 1977.

Marriage, Divorce and the Church. London: S.P.C.K., 1972.

Miller, Haskel1 M. Barriers and Bridges to Brotherhood. New York: Abingdon Press, 1962.

Mobley, Harris W. The Ghanaian's Image of the Missionary. Leiden: E. J. Bril1, 7963 .

New Look of Christianity in Africa, A. Geneva: World Student Christian Federation, 1972.

Nida, Eugene E. Customs and Cultures. New York: Harper and! Brothers, 1954.

Niebuhr, H. Richard. Christ and Cultures. New York: Harper and Brothers, 1956.

- The Social Sources of Denominationalism. Hamden, CT:

Shoe String Press, 1954.

"Notes and Querries," quoted in Gough, Kathleen. The Nayars and the Definition of Marriage. In Bohannan, PauT and Middleton, John. Marriage, Family and Residence. New York: Natural History Press, 1968.

Oosthuisen, G. C. Post Christianity in Africa. London: C. Hurst and Co., 1968.

Parrinder, Geoffrey, The Bible and Polygamy. London: S.P.C.K., 1950.

Parson, Robert T. The Churches and Ghana Society, 1918-1955. Leiden: E. J. Bri11, 1963.

Phillips, Arthur. Survey of African Marriage and Family Life. London: Oxford University Press, 1953.

Pretorius, H. "Childlessness." In T. D. Verryn, ed. Church and Marriage in Modern Africa. Johannesburg: Zenith Printers, 1975.

Price, Thomas. African Marriage. London: SCM Press, 1956.

Radcliff-Brown, A. R. and Forde, Daryl1. African Systems of

Kinship and Marriage. London: Oxford University Press, 1964. 
Sahlins, Marshall D. Tribesmen. Englewood Cliffs, NJ: PrenticeHall, Inc., 1958.

Schillebeeckx, E. 0. P. Marriage--Human Reality and Saving Mystery. New York: Sheed and Ward, 1965.

Shorter, Aylard W. F. African Culture and the Christian Church. London: Jeoffrey Chapman, 1973.

Skinner, Elliot P. "Intergenerational Conflict Among the Mossi." In Bohannan, Paul and Middleton, John, ed. Marriage, Family and Residence. Garden City, NY: The Natural History Press, 1968.

Tenney, Merrill C. The Zondervan Pictorial Encyclopedia of the Bible. Grand Rapids: Zondervan Publishing House, 1975.

Trobish, Walter. I Married You. New York: Harper and Row Publishers, 1975.

Tufuo, J. V. and Donkor, C. E. Ashantis of Ghana, People with a Soul. Accra: Anuwuo Educational Publications, 1969.

Verryn, T. D. Church and Marriage in Modern Africa. Johannesburg: Zenith Printers, 1975.

Vinogratoff, Paul. "Outline of Historical Juriprudence." In Phillips, Arthur, ed. Survey of African Marriage and Family Life. London: Oxford University Press, 1953.

Von Allmen, J. J. Vocabulary of the Bible. London: Lutterworth Press, 1959.

Wedel, Theodore 0. "The Epistle to the Ephesians." The Interpreter's Bible. Vol. 10. New York: Abingdon Press, T953.

Westermarck, Edward. The History of Marriage. Vol. 3. London: Macmillan and Co., 1921.

White, Ellen G. Adventist Home. Nashville, TN: Southern Publishing Association, 1952.

- Christ's Object Lessons. !lashington, D.C.: Review and Herald Publishing Association, 1941.

- Counsels to Parents, Teachers and Students. Mountain View, CA: Pacific Press Publishing Association, 1913. - Desire of Ages, The. Mountain View, CA: Pacific Press Publishing Association, 1940.

- Great Controversy, The. Mountain View, CA: Pacific Press Publishing Association, 1911. 
- Patriarchs and Prophets. Mountain View, CA: Pacific Press Publishing Association, 1958.

- Selected Messages. Washington, D.C.: Review and Herald Publishing Association, 1958.

- Spiritual Gifts. Vol. 3. Washington, D.C.: Review and Herald Publishing Association, 1945.

- Testimonies to the Church. Vol. 2. Mountain View,

$\overline{C A}$ : Pacific Press Publishing Association, 1948.

Whooley, B. "Marriage in Africa." In T. D. Verryn, ed. Church and Marriage in Modern Africa. Johannesburg: Zenith Printers, 1975.

Wold, Joseph Conrad. God's Impatience in Liberia. Grand Rapids:

William B. Eerdmans' Publishing Co., 1969.

Working Policies. Accra-Ghana. West African Union Mission, 1972.

\section{Articles}

Boer, Harry. "Polygamy." Frontier 2 (Winter 1968-69):25, 26.

Busia, Abrefa Kofi. "Freedom and Unity in Christian Society." International Review of Missions 52 (July 1963):452.

Hastings, Adrian. "The Church Response to African Marriage." African Ecclesiastical Review 3/3 (1971):196.

Heppensta11, Edward. "Creed, Authority and Freedom." Ministry, April 1979, p. 14.

Holst, Robert. "Polygamy and the Bible." International Review of Missions 56/222 (Apri1 1967):209, 210.

Hughes, Kenneth. "The Church and Marriage in Africa." The Christian Century 82/7 (February 12, 1965):207.

Taber, Charles. "The Missionary: Wrecker, Builder or Catalyst." Practical Anthropology 17 (June 1972):87.

Tippet, Alan. "Polygamy as a Missionary Problem: The Anthropological Issues." Practical Anthropology 17 (March/April 1970): 76 .

Trobish, Walter. "Congregational Responsibility for the Christian." Practical Anthropology 13 (September-0ctober 1966):211. 


\section{Other Sources}

"First Epistle of Paul the Apostle to Timothy, The." [1 Tim 3:2]. F. D. Nichol, ed. Seventh-day Adventist Bible Commentary. Vol. 7. Washington, D.C.: Review and Herald Publishing Association, 1953-1957.

General Conference of Seventh-day Adventists. "Missionary Round Table (1913, 1926)." Washington, D.C.: General Conference - of Seventh-day Adventists, Archives.

Maberly, Clifton R. "The Polygamous Marriage Variant: The Policy and Practice of a Church." A Research Project, Berrien Springs, Michigan: Andrews University, 1975.

Staples, Russell L. "The Church and Polygamy in Sub-Saharan Africa." An unpublished working paper produced at the request of the General Conference, September 1981. (Mimeographed.)

White, Ellen G. MS 271/2, 1900. Ellen G. White Research Center, Andrews University, Berrien Springs, Michigan. 
VITA

Name: Jean-Jacques Bouit

Date and Place of Birth: February 29, 1936

Papeete, Tahiti

Under Graduate and Graduate Schools Attended:

Séminaire Adventiste du Salève

ColTonges\% saleve, France 1952-1959

Atlantic Union College

South Lancaster, MA

Andrews University

Berrien Springs, MI

Degree Awarded:

$$
\begin{aligned}
& 1962 \text { - Bachelor of Arts in Theology } \\
& \text { Atlantic Union College } \\
& 1970 \text { - Master of Divinity } \\
& \text { Andrews University } \\
& 1982 \text { - Doctor of Ministry } \\
& \text { Andrews University }
\end{aligned}
$$

Work Experience:

1964-1969 - Pastor, Central California Conference

1970-1972 - Bible Teacher, Adventist Secondary School Bouake, Ivory Coast

1973-1978 - President of Ivory Coast Mission

1979- - Education and Stewardship Director of West African Union Mission 